Prepared in cooperation with the U.S. Department of Energy, Office of River Protection

\title{
A Probabilistic Assessment of Tephra-Fall Hazards at Hanford, Washington, from a Future Eruption of Mount St. Helens
}

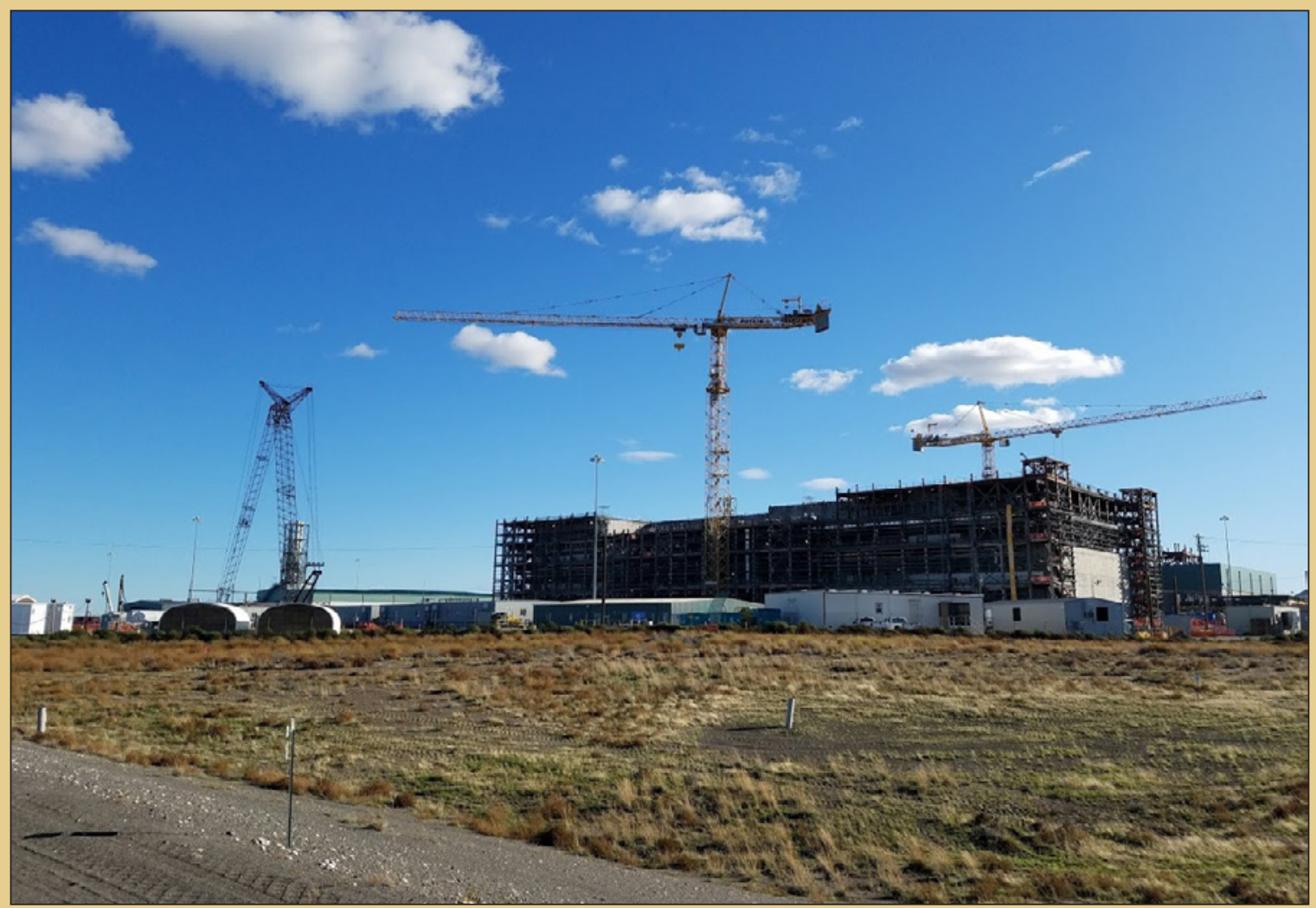

Open-File Report 2020-1133 
Cover. The Hanford pre-treatment facility, under construction, November 2016. USGS photo by Larry G. Mastin. 


\section{A Probabilistic Assessment of Tephra-Fall Hazards at Hanford, Washington, from a Future Eruption of Mount St. Helens}

By Larry G. Mastin, Alexa Van Eaton, and Hans F. Schwaiger

Prepared in cooperation with the U.S. Department of Energy, Office of River

Protection

Open-File Report 2020-1133 


\title{
U.S. Department of the Interior DAVID BERNHARDT, Secretary
}

\author{
U.S. Geological Survey \\ James F. Reilly II, Director
}

\section{U.S. Geological Survey, Reston, Virginia: 2020}

For more information on the USGS - the Federal source for science about the Earth, its natural and living resources, natural hazards, and the environment-visit https://www.usgs.gov or call 1-888-ASK-USGS.

For an overview of USGS information products, including maps, imagery, and publications, visit https://store.usgs.gov.

Any use of trade, firm, or product names is for descriptive purposes only and does not imply endorsement by the U.S. Government.

Although this information product, for the most part, is in the public domain, it also may contain copyrighted materials as noted in the text. Permission to reproduce copyrighted items must be secured from the copyright owner.

Suggested citation:

Mastin, L.G., Van Eaton, A., and Schwaiger, H.F., 2020, A probabilistic assessment of tephra-fall hazards at Hanford, Washington, from a future eruption of Mount St. Helens: U.S. Geological Survey Open-File Report 2020-1133, 54 p., https://doi.org/10.3133/ofr20201133.

Associated data for this publication:

Mastin, L.G., Van Eaton, A., and Schwaiger, H.F., 2020, Data used to develop a probabilistic assessment of tephra-fall hazards at Hanford, Washington: U.S. Geological Survey Data Release, https://doi.org/10.5066/P9VPFXOR.

ISSN 2328-0328 (online) 


\section{Acknowledgments}

This report was prepared under contract with the U.S. Department of Energy, Office of River Protection (DOE/ORP). Except for a few minor formatting changes, the removal of a few tables, and the addition of a second appendix, it is identical to a report submitted to DOE/ORP. 


\section{Contents}

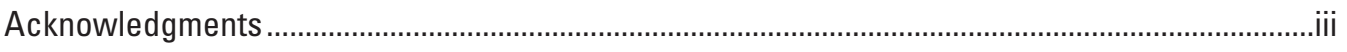

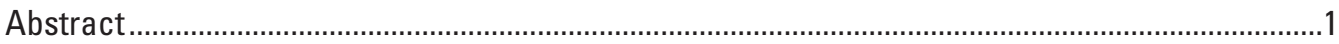

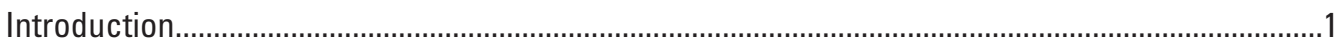

The Explosive History of Mount St. Helens .....................................................................

What We Learned from the Eruption of 1980 .................................................................

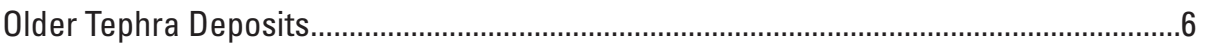

Methods

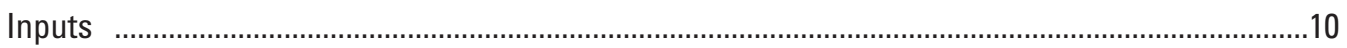

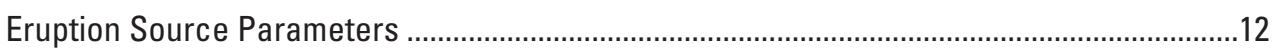

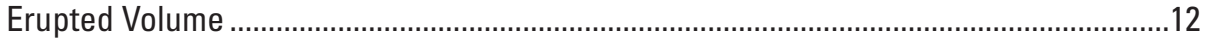

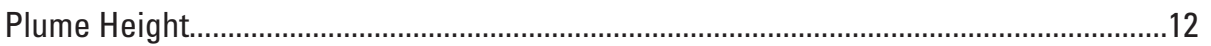

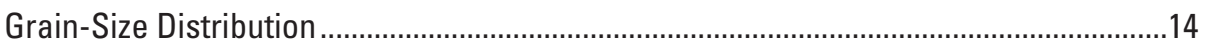

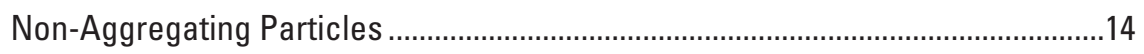

Mean Aggregate Size $\left(\mu_{\text {agg }}\right)$..........................................................................14

Mass Fraction Aggregating Ash .....................................................................15

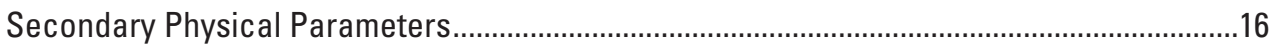

Meteorological Inputs ................................................................................................

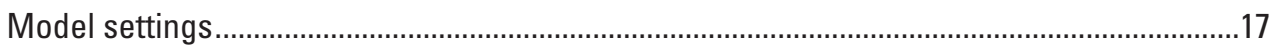

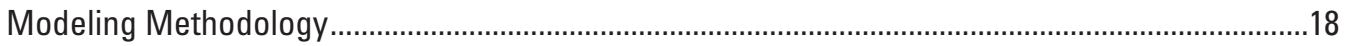

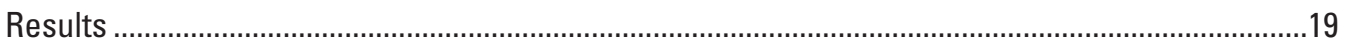

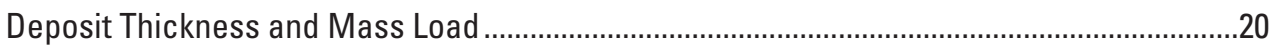

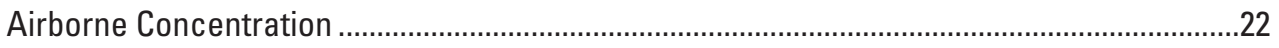

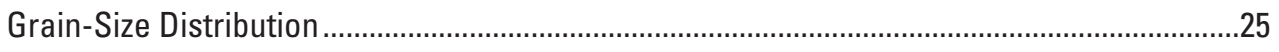

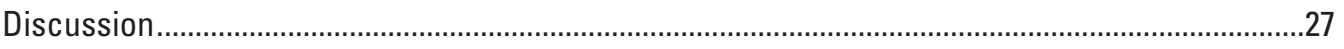

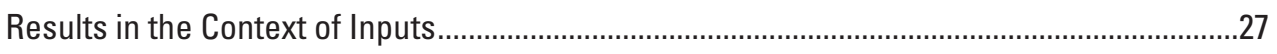

Comparison with Measured Airborne Concentrations ...........................................................29

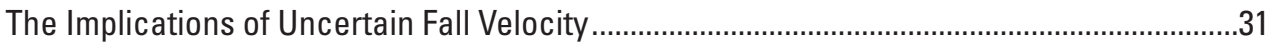

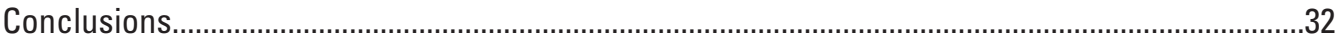

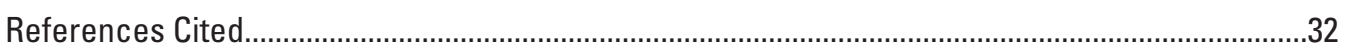

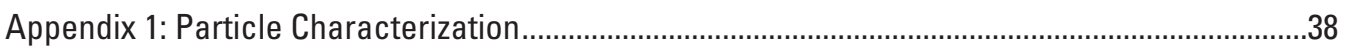

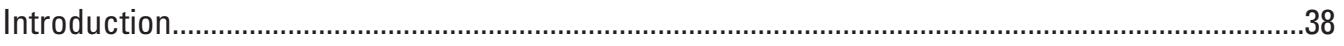

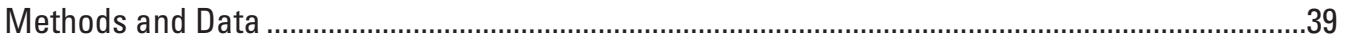

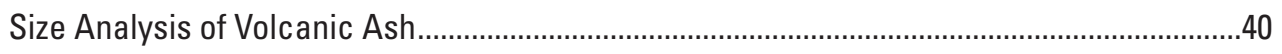

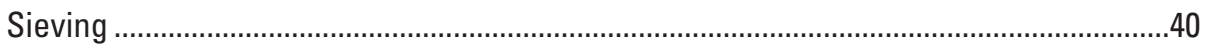

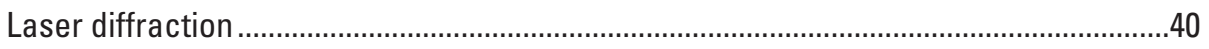

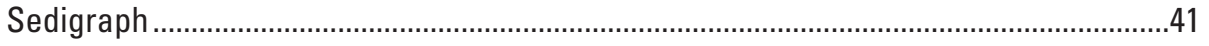

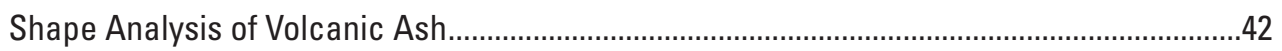

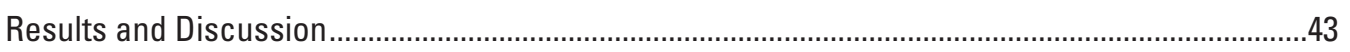

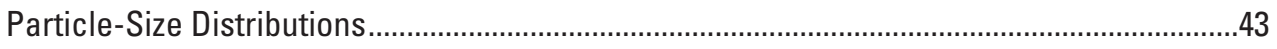

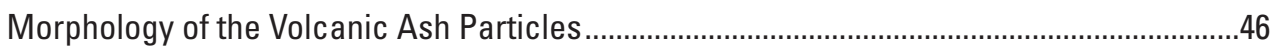

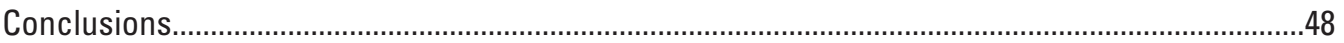


Appendix 2: Effect of Extremely Large Eruptions of Mount St. Helens on Tephra-Fall Thickness and Airborne Ash Concentration at the Hanford Site, Washington.

by Larry G. Mastin, Michael Clynne, Manuel Nathenson, John Pallister, and

Alexa Van Eaton

Introduction. .49

Size of the Largest Eruptions at Mount St. Helens............................................................................49

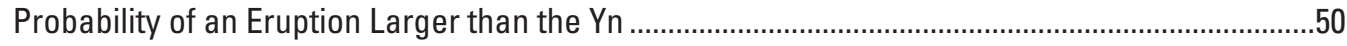

Effect of Large Eruptions on our Model Results .........................................................................51

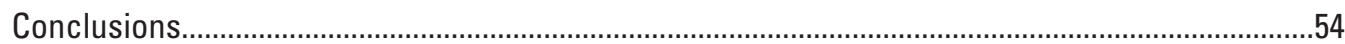

\section{Figures}

1. Maps and images from the May 18, 1980, eruption at Mount St. Helens...........................5

2. Graphs showing particle-size distributions of tephra-fall from the May 18, 1980, eruption at Mount St. Helens .........................................................................................

3. Map and graphs showing thickness of the Yn and 1980 deposits at Mount St. Helens...9

4. Model grid used by the Ash3d model for simulations ........................................................10

5. Illustration of the two types of probability density functions used to assign

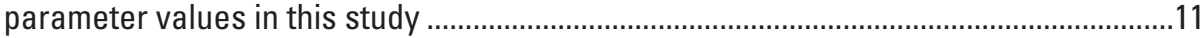

6. Correlations between plume height and eruption rate or erupted volume .....................13

7. Diagram showing processes that influence the distribution of fine, distal ash...............14

8. Graphs showing settling velocity versus transport distance and diameter for particulate matter falling at Hanford, Washington ...........................................................16

9. Distribution of inputs used in the simulation.......................................................................18

10. Graphs of probability of exceedance of a given tephra thickness or ash concentration versus thickness and concentration .......................................................19

11. Calculated values of tephra-fall thickness in a "1-in-10,000-year event" .....................20

12. Maps of tephra deposition for four runs whose deposit thickness at Hanford is closest to "1-in-10,000-year event" ................................................................................21

13. Tephra-fall duration at Hanford, Washington, versus eruption duration .........................22

14. Graphs showing airborne ash concentration versus time for eruption simulations.......24

15. Graphs showing grain-size distributions at Hanford, Washington, for several

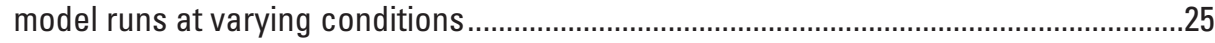

16. Contrasting ash-cloud shapes from small and large eruptions........................................28

17. Graph of slopes of lines on plots of log thickness versus square root of

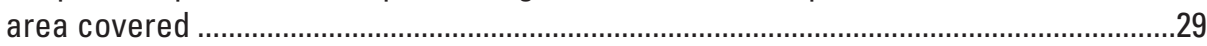

18. Sketches showing airborne particle sampling tools .......................................................30

19. Diagram showing control volume into which ash is falling at the mass accumulation rate

20. Illustration of the path that might be taken by aggregates or particles falling near the intake of an HVAC system of generic design ................................................................32

1.1. Scanning electron microscope images of volcanic ash used in this study ....................39

1.2. Schematic showing the particle characterization methods used on different sizes

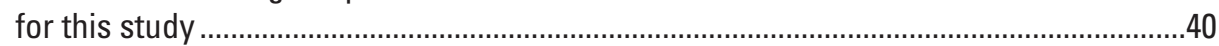

1.3. Images showing steps of particle-shape analysis ........................................................4 
1.4. Histograms showing particle-size distributions from sieve-laser diffraction analysis of each volcanic ash sample collected in the field

1.5. Comparison of parent versus resuspended ash from Portable laboratory experiments, using material from Mount St. Helens, Washington, and the Valley of Ten Thousand Smokes, Alaska

1.6. Histograms showing comparison of the particle-size distribution of the proximal May 18, 1980, ash sample from this study (gray bars) with other samples from the same eruption.

1.7. Histogram of feret diameters from each of the samples analyzed for shape

1.8. Plots showing the results of particle-shape analysis on the three samples of volcanic ash.

2.1. Graph showing the number of Cascade eruptions versus age, in thousands of years before present.

2.2. Graphs showing volume and thickness of tephra deposits indicated by model runs ....52

2.3. Graphs showing the cumulative distribution function and the probability distribution functions as a function of dense-rock equivalent volume.....

\section{Tables}

1. List of variables

2. Tephra deposits from large Plinian eruptions of Holocene age at Mount St. Helens, Washington

3. Summary of procedures used to assign eruption source parameters in each simulation

4. Values of secondary physical parameters and model settings used in each simulation

5. Total grain-size distribution from the 1980 deposit and used in this study

6. Mass fraction of fine ash assigned to different size bins for aggregates

7. Mass fraction of fine ash in selected recent eruption deposits.

8. Threshold values of tephra-fall thickness in millimeters and airborne concentration at different exceedance probabilities

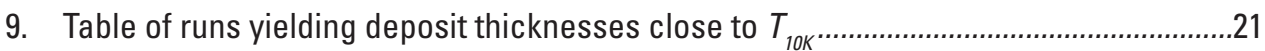

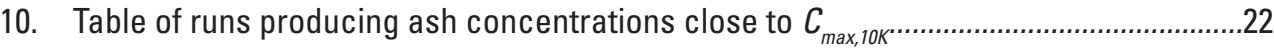

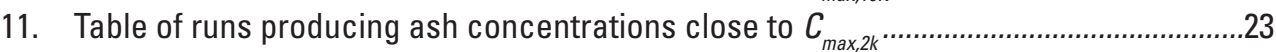

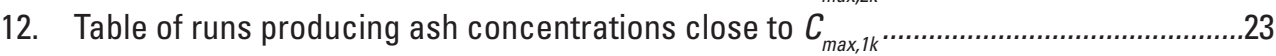

13. Run numbers producing ash concentrations at Hanford, Washington,

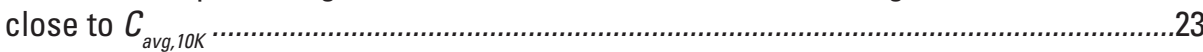

14. Grain-size distribution at Hanford, Washington for runs where $T \cong T_{10 k} \ldots \ldots \ldots \ldots \ldots \ldots \ldots \ldots \ldots . . .25$

15. Grain-size distribution at Hanford for runs producing ash concentrations close to $C_{\text {max }, 10 \kappa . .}$

16. Grain-size distribution at Hanford for runs producing ash concentrations close to $C$

17. Estimated range of uncertainty in secondary physical parameters and their possible effects on results 
18. Measurements of suspended particle concentrations made during volcanic eruptions

19. Tabulated fall velocities of ash aggregates from different sources .................................31

1.1. Volcanic ash samples used in particle characterization...................................................39

1.2. Particle-size distributions using combined sieve-laser diffraction analyses, shown as cumulative percent less than a given size fraction

1.3. Sieve-sedigraph particle-size distributions, shown as cumulative weight percent

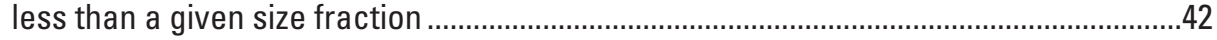

1.4. Particle shape descriptors used in this study .............................................................43

1.5. Samples and number of particles used in shape analysis ..............................................43

2.1. Thickness of the largest tephra layers at Mount St. Helens, at 8-11 kilometers from the vent.

2.2. Number of eruptions in the Smithsonian Institution's Global Volcanism Program Volcanoes of the World Database, listed by size

2.3. Effect of the addition of a small number of high-volume simulations on the tephra-fall thickness, maximum airborne ash concentration, and average airborne ash concentration at Hanford, Washington, having an annual probability of one in 10,000

2.4. Values of tephra-fall thickness, maximum airborne ash concentration and average airborne ash concentration at Hanford, Washington. 


\section{Conversion Factors}

International System of Units to U.S. customary units

\begin{tabular}{|c|c|c|}
\hline Multiply & By & To obtain \\
\hline \multicolumn{3}{|c|}{ Length } \\
\hline centimeter $(\mathrm{cm})$ & 0.3937 & inch (in.) \\
\hline millimeter (mm) & 0.03937 & inch (in.) \\
\hline meter $(\mathrm{m})$ & 3.281 & foot $(\mathrm{ft})$ \\
\hline kilometer (km) & 0.6214 & mile (mi) \\
\hline kilometer (km) & 0.5400 & mile, nautical (nmi) \\
\hline meter $(\mathrm{m})$ & 1.094 & yard (yd) \\
\hline \multicolumn{3}{|c|}{ Area } \\
\hline square meter $\left(\mathrm{m}^{2}\right)$ & 0.0002471 & acre \\
\hline hectare (ha) & 2.471 & acre \\
\hline square hectometer $\left(\mathrm{hm}^{2}\right)$ & 2.471 & acre \\
\hline square kilometer $\left(\mathrm{km}^{2}\right)$ & 247.1 & acre \\
\hline square centimeter $\left(\mathrm{cm}^{2}\right)$ & 0.001076 & square foot $\left(\mathrm{ft}^{2}\right)$ \\
\hline square meter $\left(\mathrm{m}^{2}\right)$ & 10.76 & square foot $\left(\mathrm{ft}^{2}\right)$ \\
\hline square centimeter $\left(\mathrm{cm}^{2}\right)$ & 0.1550 & square inch $\left(\mathrm{ft}^{2}\right)$ \\
\hline square hectometer $\left(\mathrm{hm}^{2}\right)$ & 0.003861 & section ( 640 acres or 1 square mile) \\
\hline hectare (ha) & 0.003861 & square mile $\left(\mathrm{mi}^{2}\right)$ \\
\hline square kilometer $\left(\mathrm{km}^{2}\right)$ & 0.3861 & square mile $\left(\mathrm{mi}^{2}\right)$ \\
\hline \multicolumn{3}{|c|}{ Volume } \\
\hline cubic meter $\left(\mathrm{m}^{3}\right)$ & 6.290 & barrel (petroleum, 1 barrel $=42$ gal) \\
\hline cubic meter $\left(\mathrm{m}^{3}\right)$ & 264.2 & gallon (gal) \\
\hline cubic decimeter $\left(\mathrm{dm}^{3}\right)$ & 0.2642 & gallon (gal) \\
\hline cubic meter $\left(\mathrm{m}^{3}\right)$ & 0.0002642 & million gallons (Mgal) \\
\hline cubic centimeter $\left(\mathrm{cm}^{3}\right)$ & 0.06102 & cubic inch $\left(\mathrm{in}^{3}\right)$ \\
\hline cubic decimeter $\left(\mathrm{dm}^{3}\right)$ & 61.02 & cubic inch $\left(\mathrm{in}^{3}\right)$ \\
\hline liter $(\mathrm{L})$ & 61.02 & cubic inch $\left(\mathrm{in}^{3}\right)$ \\
\hline cubic decimeter $\left(\mathrm{dm}^{3}\right)$ & 0.03531 & cubic foot $\left(\mathrm{ft}^{3}\right)$ \\
\hline cubic meter $\left(\mathrm{m}^{3}\right)$ & 35.31 & cubic foot $\left(\mathrm{ft}^{3}\right)$ \\
\hline cubic meter $\left(\mathrm{m}^{3}\right)$ & 1.308 & cubic yard $\left(\mathrm{yd}^{3}\right)$ \\
\hline cubic kilometer $\left(\mathrm{km}^{3}\right)$ & 0.2399 & cubic mile $\left(\mathrm{mi}^{3}\right)$ \\
\hline cubic meter $\left(\mathrm{m}^{3}\right)$ & 0.0008107 & acre-foot (acre-ft) \\
\hline cubic hectometer $\left(\mathrm{hm}^{3}\right)$ & 810.7 & acre-foot (acre-ft) \\
\hline
\end{tabular}




\section{Conversion Factors - Continued}

\begin{tabular}{lll}
\hline \multicolumn{1}{c}{ Multiply } & \multicolumn{1}{c}{ By } & \multicolumn{1}{c}{ To obtain } \\
\hline gram $(\mathrm{g})$ & \multicolumn{2}{c}{ Mass } \\
kilogram $(\mathrm{kg})$ & 0.03527 & ounce, avoirdupois $(\mathrm{oz})$ \\
metric ton $(\mathrm{t})$ & 2.205 & pound avoirdupois $(\mathrm{lb})$ \\
metric ton $(\mathrm{t})$ & 1.102 & ton, short $[2,000 \mathrm{lb}]$ \\
\hline & 0.9842 & ton, long $[2,240 \mathrm{lb}]$ \\
\hline kilogram per cubic meter & \multicolumn{2}{c}{ Density } \\
$\quad\left(\mathrm{kg} / \mathrm{m}^{3}\right)$ & 0.06242 & pound per cubic foot $\left(\mathrm{lb} / \mathrm{ft}^{3}\right)$ \\
gram per cubic centimeter & 62.4220 & pound per cubic foot $\left(\mathrm{lb} / \mathrm{ft}^{3}\right)$ \\
$\quad\left(\mathrm{g} / \mathrm{cm}^{3}\right)$ & & \\
\hline
\end{tabular}

Temperature in degrees Celsius $\left({ }^{\circ} \mathrm{C}\right)$ may be converted to degrees Fahrenheit $\left({ }^{\circ} \mathrm{F}\right)$ as follows:

$$
{ }^{\circ} \mathrm{F}=\left(1.8 \times{ }^{\circ} \mathrm{C}\right)+32 .
$$

Temperature in degrees Fahrenheit $\left({ }^{\circ} \mathrm{F}\right)$ may be converted to degrees Celsius $\left({ }^{\circ} \mathrm{C}\right)$ as follows:

$$
{ }^{\circ} \mathrm{C}=\left({ }^{\circ} \mathrm{F}-32\right) / 1.8 \text {. }
$$

\section{Abbreviations}

$\begin{array}{ll}\text { DOE/ORP } & \text { U.S. Department of Energy, Office of River Protection } \\ \text { DRE } & \text { Dense-rock equivalent } \\ \text { ECMWF } & \text { European Centre for Medium-Range Weather Forecasts } \\ \text { ERA } & \text { European Centre for Medium-Range Weather Forecasts reanalysis } \\ \text { GSD } & \text { grain-size distribution } \\ \text { GVP } & \text { Global Volcanism Program } \\ \text { HVAC } & \text { heating, ventilation, and air conditioning } \\ \text { MSH } & \text { Mount St. Helens } \\ \text { pdf } & \text { probability density function } \\ \text { PM } & \text { particulate matter } \\ \text { SEM } & \text { scanning electron microscope } \\ \text { TSP } & \text { total suspended particulates } \\ \text { USGS } & \text { U.S. Geological Survey } \\ \text { VEI } & \text { Volcanic Explosivity Index } \\ \text { VTTS } & \text { Valley of Ten Thousand Smokes } \\ \text { WTP } & \text { Waste Treatment and Immobilization Plant }\end{array}$





\title{
A Probabilistic Assessment of Tephra-Fall Hazards at Hanford, Washington, from a Future Eruption of Mount St. Helens
}

\author{
By Larry G. Mastin, Alexa Van Eaton, and Hans F. Schwaiger
}

\section{Abstract}

Hanford, Washington (USA) is the construction site of a multi-billion-dollar high-level nuclear waste treatment facility. This site lies 200 kilometers $(\mathrm{km})$ east of Mount St. Helens (MSH), the most active volcano in the contiguous United States. Tephra from a future MSH eruption could pose a hazard to the air intake and filtration systems at this plant. In this report, we present a probabilistic estimate of the amount of tephra that could fall, and the concentrations of airborne ash that could occur at the Hanford Site during a future eruption. Mount St. Helens has produced four large explosive eruptions in approximately the past 500 years, suggesting that its annual probability of eruption $\left(P_{1}\right)$ is roughly $4 / 500=0.008$. Assuming that a large eruption occurs, we calculate the probability $\left(P_{3 \mid 1}\right)$ of a given fall deposit thickness or airborne concentration at Hanford by running about 10,000 simulations of ash-producing eruptions using the atmospheric transport model Ash3d. In each simulation, we calculate the pattern of tephra dispersal, deposit thickness at Hanford, and airborne ash concentration at ground level. As input for each simulation, we choose meteorological conditions from a randomly chosen time in the historical record between 1980 and 2010, using data from the European Centre for Medium-Range Weather Forecasting (ECMWF) Reanalysis (ERA) Interim model. The volume (dense-rock equivalent) of each simulated eruption is randomly chosen from a uniform probability distribution on a log scale from the range of magma volumes (0.008-2.3 cubic kilometers $\left.\left[\mathrm{km}^{3}\right]\right)$ estimated for late Holocene eruptions at MSH. Plume heights and durations of each eruption are chosen using empirical correlations between volume, height, and eruption rate, which account for the fact that larger eruptions have higher plumes and last longer. We construct summary tables of final deposit thickness $(T)$, maximum ground-level airborne concentration $\left(C_{\max }\right)$, and average ground-level airborne concentration $\left(C_{a v g}\right)$ during tephra-fall for each run. Each table is sorted and ranked by decreasing value of $T, C_{\max }$, or $C_{a v g}$. Conditional probabilities $\left(P_{3 \mid 1}\right)$ are derived by dividing rank by $\mathrm{n}+1$, where $\mathrm{n}$ is the total number of successful runs. For example, a deposit thickness of 5.10 centimeters $(\mathrm{cm})$ from run 446 is ranked 123 of 9,785 successful runs, yielding $P_{3 \mid 1}=123 / 9,786=0.01257$. Its annual probability is $P=P_{1} \cdot P_{3 \mid 1}=0.008 \times 0.01257=0.000101$. By interpolation, the deposit thickness $\left(T_{10 k}\right)$ having an annual probability of 1 in $10,000(P=0.0001)$ is $5.11 \mathrm{~cm}$. Analogous concentration values are $C_{\max , 10 k}=3,819$ and $C_{\text {avg, } 10 k}=1,513$ milligrams per cubic meter $\left(\mathrm{mg} / \mathrm{m}^{3}\right)$, respectively. Independent calculations using the known mass accumulation rate of the deposit $\left(\dot{M}_{d}=0.001-0.006\right.$ kilograms per square meter per second $\left[\mathrm{kg} / \mathrm{m}^{2} / \mathrm{s}\right]$ ), aggregate fall velocities $(u=0.3-0.8$ meters per second $[\mathrm{m} / \mathrm{s}])$, and the simple formula $C=\dot{M}_{d} / u$, yield similar results, although highly variable fall velocities add significant uncertainty. This formula implies that deposit accumulation rates of millimeters $(\mathrm{mm})$ to greater than $1 \mathrm{~cm}$ per hour, which are not uncommon during heavy ash fall, are associated with airborne concentrations of $10^{2}-10^{3}$ milligrams per cubic meter $\left(\mathrm{mg} / \mathrm{m}^{3}\right)$. These concentrations are much higher than published measurements $\left(10^{-3}-10^{1}\right.$ $\mathrm{mg} / \mathrm{m}^{3}$ ), which record only suspended particles sampled in sheltered areas. During heavy ashfall, most fine ash falls as aggregates. Whether such aggregates will be ingested into air ducts will depend on the aggregate size and fall rate, the fragility of the aggregates, the air duct geometry, intake velocity, and other factors.

\section{Introduction}

Radioactive waste generated during World War II and the Cold War were originally contained in 177 underground tanks at the Hanford Site near Richland, Washington. In support of its nationwide environmental cleanup of nuclear facilities, the U.S. Department of Energy (DOE), Office of River Protection (ORP) is constructing a facility and supporting infrastructure (the Waste Treatment and immobilization Plant [WTP]) to retrieve, process and vitrify this waste for permanent storage. An explosive eruption from Mount St. Helens (MSH) could potentially deposit enough ash at Hanford to temporarily disrupt site operations (for example, WTP). DOE Standards that provide criteria and guidance for natural phenomena hazards analysis (for example DOE-STD-1020, Section 8) require that this be stated in probabilistic terms. For this project, it is interpreted to mean, "What deposit thickness and airborne ash concentration could be expected at Hanford given a Mount St. Helens eruption with an annual exceedance probability of 1 in 10,000?" We notate the thickness and concentration values at this threshold as $T_{10 K}$ and $C_{10 k}$, respectively (see table 1 for a list of variables). This report provides a methodology to quantify these values. 
In 2011, Hoblitt and Scott (2011) found that ashfall at the Hanford site would most likely come from MSH, rather than Mount Rainier, Hood, Adams, or other regional volcanoes. Hoblitt and Scott (2011) also estimated $T_{10 K}$ empirically from volcanological and meteorological data, by breaking the problem into three components:

1. What is the annual probability of a large ash-producing eruption $\left(P_{1}\right)$ from MSH? Hoblitt and Scott noted that four large eruptions had occurred at MSH in approximately the past 500 years, suggesting that $P_{1} \cong 4 / 500=0.008$.

2. Given a large eruption, what is the probability that wind will be blowing toward Hanford $\left(P_{211}\right)$ ? From historical records they concluded that $\left(P_{2 \mid 1}\right) \cong 0.18$.

3. Given an eruption with wind blowing toward Hanford, what is the exceedance probability of a given amount of ash fall (for example, 1,5 , or 10 centimeters [cm]) at Hanford $\left(P_{3 \mid 2}\right)$ ? To address this question, they examined the thickness of 14 large eruptions whose deposits could be tracked 200 kilometers $(\mathrm{km})$. The thickest deposited $10 \mathrm{~cm}$, suggesting $P_{3 \mid 2}=1 /(14+1)=0.067$ of greater than $10 \mathrm{~cm}$ thickness. The product $P_{1} \cdot P_{2 \mid l} \cdot P_{3 \mid 2}=0.008 \cdot 0.18 \cdot 0.067$ is about 1 in 10,000 , implying that $T_{10 K} \simeq 10 \mathrm{~cm}$.

Snow and Nelson (2012) used this result, and an assumed deposit density of 1,125 kilograms per cubic meter $\left(\mathrm{kg} / \mathrm{m}^{3}\right)$, to calculate an approximate mass load $(M)$ of 112 kilograms per square meter $\left(\mathrm{kg} / \mathrm{m}^{2}\right)$. Assuming a settling rate of $u=1.7$ meters per second $(\mathrm{m} / \mathrm{s})$ and an ashfall duration of $D_{d}=12$ hours (hrs; 43,200 seconds [s]), they calculated an airborne tephra concentration at ground level of $C=M /\left(D_{d} u\right)=$ about 1,500 milligrams per cubic meter $\left(\mathrm{mg} / \mathrm{m}^{3}\right)$. Airborne concentrations this high could be economically challenging to filter.

A more sophisticated analysis could provide a more robust result. The erupted magma volume, plume height, eruption duration, and size distribution resulting from the next large eruption are uncertain; but a reasonable range of estimates can be made from past eruptions at Mount St. Helens and from eruptions of similar size around the world. Given specified inputs, the tephra-fall thickness at Hanford can be calculated using transport models such as the U.S. Geological Survey (USGS) Ash3d model (Schwaiger and others, 2012).

The purpose of this study is to use a Monte Carlo procedure and approximately 10,000 model simulations to calculate probabilities of exceedance of specified levels of ashfall or airborne concentration $\left(P_{3||}\right)$, given an eruption whose size and other characteristics range within likely bounds for Mount St. Helens. The probability $P_{3 \mid 1}$ replaces the product $P_{2 \mid 1} \cdot P_{3 \mid 2}$ from Hoblitt and Scott (2011). Combined with $P_{1}$, our results yield new values of tephra-fall thickness $\left(T_{10 K}\right)$ and maximum $\left(C_{\text {max }, 10 k}\right)$ or average $\left(C_{\text {avg, }, 10 k}\right)$ airborne ash concentration having an annual probability of occurrence of 1 in 10,000. Key inputs for each simulation are assigned following Monte Carlo procedures, using methods similar to other studies (Stirling and Wilson, 2002; Hurst and Smith, 2004; Mastrolorenzo and others, 2008; Amigo, 2013; Bear-Crozier and others, 2016).

Table 1. List of variables.

[Abbreviations: DRE, dense-rock equivalent; hr, hour; $\mathrm{kg}$, kilogram; $\mathrm{kg} / \mathrm{m}^{2}$, kilogram per square meter; $\mathrm{kg} / \mathrm{m}^{3}$, kilogram per cubic meter; $\mathrm{kg} / \mathrm{m}^{2} / \mathrm{s}, \mathrm{kilogram}$ per square meter per second; $\mathrm{kg} / \mathrm{s}$, kilogram per second; $\mathrm{km}$, kilometer, $\mathrm{km}^{2}$, square kilometer; $\mathrm{km}^{3}$, cubic kilometer; $\mathrm{m}$, meter; $\mathrm{m} / \mathrm{s}$, meter per second; $\mathrm{m}^{2} / \mathrm{s}$, square meter per second; $\mathrm{mm}$, millimeter; $\mathrm{mg} / \mathrm{m}^{3}$, milligram per cubic meter; $\mathrm{mg}$-s $/ \mathrm{m}^{3}$, milligram-seconds per cubic meter; yr, year]

\begin{tabular}{|c|c|c|}
\hline Variable & Description & Units \\
\hline$A$ & Area on ground surface & $\mathrm{m}^{2}$ \\
\hline$a, b, c$ & Ellipsoid semi-axes & $\mathrm{m}$ \\
\hline$C_{\max }$ & Maximum airborne concentration during the period of Tephra-fall & $\mathrm{mg} / \mathrm{m}^{3}$ \\
\hline$C_{a v g}$ & Average airborne concentration during the period of Tephra-fall (dosage divided by fall duration) & $\mathrm{mg} / \mathrm{m}^{3}$ \\
\hline$C_{\max , 2 K}$ & Value of the maximum airborne ash concentration at Hanford having recurrence interval of $2,000 \mathrm{yrs}$ & $\mathrm{mg} / \mathrm{m}^{3}$ \\
\hline$C_{a v g, 2 K}$ & Value of the average airborne ash concentration at Hanford having recurrence interval of 2,000 yrs & $\mathrm{mg} / \mathrm{m}^{3}$ \\
\hline$C_{\max , I K}$ & Value of the maximum airborne ash concentration at Hanford having recurrence interval of $1,000 \mathrm{yrs}$ & $\mathrm{mg} / \mathrm{m}^{3}$ \\
\hline$C_{a v g, 1 K}$ & Value of the average airborne ash concentration at Hanford having recurrence interval of $1,000 \mathrm{yrs}$ & $\mathrm{mg} / \mathrm{m}^{3}$ \\
\hline
\end{tabular}


Table 1. List of variables.-Continued

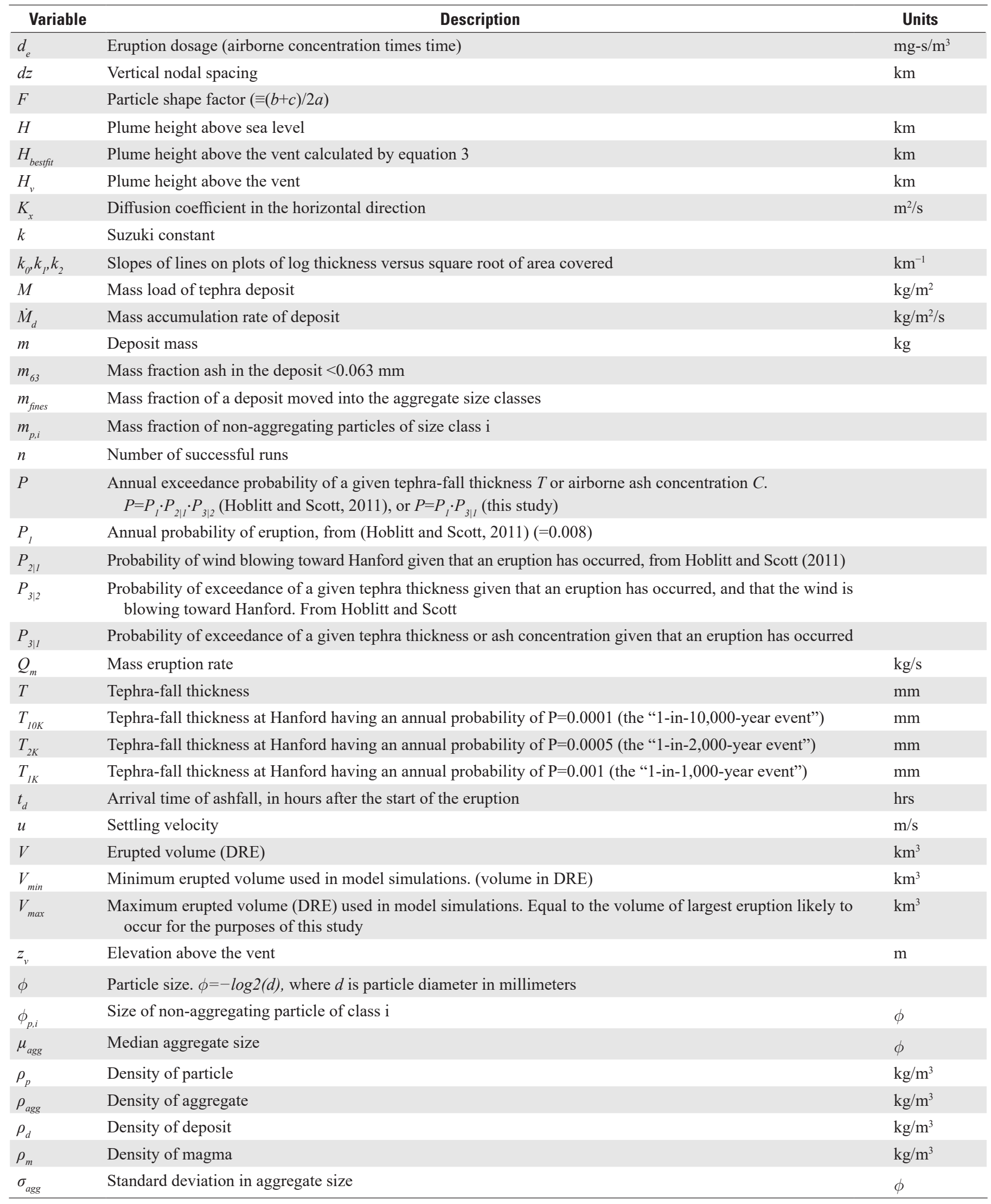


An accompanying study, appendix 1, characterizes the size and shape of tephra particles that have been tested for resuspension properties as part of this Department of Energy Ashfall Project (Etyemezian and others, 2019). The appendix was added as a means of publishing results that were contracted by DOE. A second appendix (appendix 2) describes a follow-up study that examines the effect that rare, very large events might have on our estimates of $T_{10 k}, C_{\max , 10 k}$, and $C_{\text {avg, } 10 k \text {. This follow-up study was taken in response to concerns }}$ expressed by the Defense Nuclear Facilities Safety Board that our original study, which did not consider such events, could understate the hazard.

\section{The Explosive History of Mount St. Helens}

Mount St. Helens is the most active and among the most explosive volcanoes in the Cascade Range of North America. The Cascade Range extends along the west coast from Lassen Peak (California) in the south to Mount Garibaldi (British Columbia) in the north, roughly the same range of latitude where the Juan de Fuca Plate subducts beneath the North American Plate at a rate of about 40 millimeters per year (mm/yr) (Coltice and others, 2017). Globally, volcanic arcs with the highest rate of volcanism are those whose subduction rates are high. The subduction rate of the Juan de Fuca Plate beneath North America is in the middle of the range of subduction rates observed worldwide (as much as $80 \mathrm{~mm} / \mathrm{yr}$ ). Magma production rates along the Cascade arc are modest in comparison with, for example, those volcanic arcs of Indonesia or the southern Andes.

Volcanism along the Cascade arc has persisted for tens of millions of years, but most individual volcanoes, like Mount St. Helens or Mount Rainier, are only hundreds of thousands of years old. Mounts Rainier, St. Helens, and other Cascade volcanoes are built on eroded volcanic centers from past geologic periods. Mount St. Helens, for example, sits atop igneous rocks with an age of 28-23 mega-annum (Ma) (Evarts and others, 1987). Mount Rainier overlies rocks of age 36-14 Ma (Vance and others, 1987). Rocks of present-day Mount Rainier erupted less than 500,000 years ago (500 kilo-annum [ka]) (Sisson and others, 2001). All Mount St. Helens rocks are younger than about $300 \mathrm{ka}$ (Clynne and others, 2008), and most of the Mount St. Helens edifice is younger than $4 \mathrm{ka}-$ younger than the pyramids of Egypt.

Stratovolcanoes, such as the main Cascade Range peaks, primarily erupt during stages lasting centuries to millennia. At Mount St. Helens, the current, highly active stage (the Spirit Lake stage) has continued since $3.9 \mathrm{ka}$; earlier stages extended from 16-10 ka (Swift Creek), and 28-18 ka (Cougar stage; (Pallister and others, 2017). Brief periods of quiesence are between these stages of activity.

In the past 4,000 years, MSH has produced nine mapped tephra deposits that can be traced tens, hundreds, or even greater than 1,000 kilometers from the volcano (Westgate, 1977; Zoltai, 1989; Carey and others, 1995; Mullineaux, 1996). By comparison, ash-producing eruptions from the neighboring volcanoes of Mounts Adams, Hood, and Rainier have been few and small during this period. At 8 kilometers from the vent, for example, the thickest post-4 ka tephra deposit from MSH (Yn of table 2) is about 2 meters (m) thick (Mullineaux, 1986; Carey and others, 1995). For comparison, at $7 \mathrm{~km}$ distance from Rainier, the thickest post4 ka Rainier deposit (the $C$ tephra) is about 30 centimeters (cm) (Mullineaux, 1974); and at $6 \mathrm{~km}$ from Mount Adams, the thickest layer (layer 23 of Hildreth and Fierstein [1997]) is less than $10 \mathrm{~cm}$. At Mount Hood, the only post- 4 ka tephra deposits were produced when domes growing south of the summit collapsed and avalanched down the steep south flank, releasing clouds of debris. Such deposits are decimeters thick near Timberline Lodge, $5 \mathrm{~km}$ south of the vent (Scott and Gardner, 2017). Thus, we infer that the tephra hazard to Hanford is primarily from eruptions of Mount St. Helens.

\section{What We Learned from the Eruption of 1980}

The May 18, 1980, eruption gave us vivid images of the hazard ash poses in central Washington. It also demonstrated some key processes that have influenced how we have set up this modeling study.

The May 18, 1980, eruption followed 2 months of precursory activity; seismicity started on March 20 and included many earthquakes of magnitude 3, 4, and even 5. Dramatic deformation of the volcano's north flank (growth of the "bulge") was underway within a few days of the onset of seismicity. Phreatic (steam) eruptions from the summit started March 27 and continued through early May. The climactic eruption on May 18, however, was not preceded by any uptick in seismicity or deformation rate in the hours or days preceding the event.

The May 18 eruption started with gravitational collapse of the north flank of the volcano, which had been destabilized by intrusion of a magma body into the upper edifice. At 8:32 a.m. local time, the north flank abruptly slid outward, uncorking the magma body whose gases expanded northward as a pyroclastic density current that destroyed about 600 square kilometers of forest. As the pyroclastic current rode over the ground surface, it entrained air and became buoyant, lifted off the ground from an area about $10 \mathrm{~km}$ north of the summit, rose to about $32 \mathrm{~km}$ in the atmosphere, and expanded as an umbrella cloud to about $150 \mathrm{~km}$ in diameter (Sparks and others, 1986; Holasek and Self, 1995) (fig. 1B).

Within a few tens of minutes after the flank collapse (Christiansen and Peterson, 1981), a vertical Plinian column began rising from the volcano's decapitated summit, reached about $15 \mathrm{~km}$ above sea level, and fluctuated between 13 and $17 \mathrm{~km}$ for the next 9 hours (Harris and others, 1981). In the first few hours, airborne ash moved downwind from both the Plinian column and the umbrella cloud. In the afternoon, ash injected by the Plinian column was supplemented by fine ash rising buoyantly from pyroclastic flows that avalanched down the volcano's north flank (fig. $1 D$ ).

The resulting ash cloud moved eastward at an average speed of 100 kilometers per hour $(\mathrm{km} / \mathrm{hr})$, reaching Yakima, Washington around 9:45 a.m. Pacific Time; Pasco, Washington 


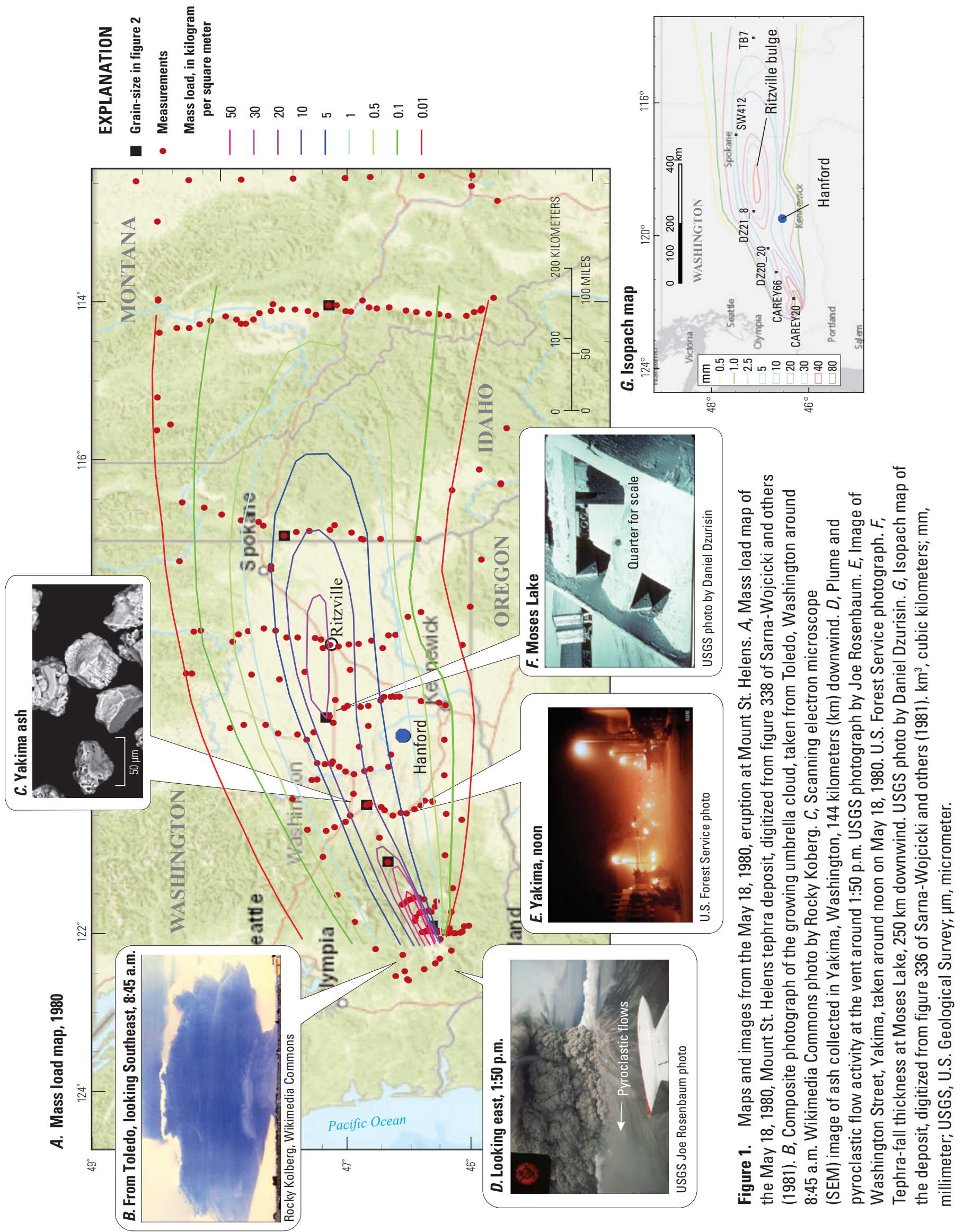


around 10:45; Spokane around noon; and Missoula, Montana at about 3:00 p.m. (Sarna-Wojcicki and others, 1981). Although the plume reached heights of $32 \mathrm{~km}(15 \pm 2 \mathrm{~km}$ for the Plinian phase), the cloud's leading edge that passed over central Washington was around $10-12 \mathrm{~km}$ elevation, where wind speeds were highest.

The tephra-fall deposit from this eruption (fig. $1 A$ ) is one of the world's most thoroughly studied. Within days, field crews drove north-south transects across Washington State, stopping regularly (red dots, fig. $1 A$ ) to measure the thickness $(T)$ of the deposit, and collect ash from measured areas $(A)$ on the ground or on flat surfaces such as the roofs of cars, stairs (fig. $1 F$ ), or sidewalks. The fresh deposit had not yet been altered by wind or by rain, allowing scientists to sample to distances of more than $600 \mathrm{~km}$, where thicknesses were a fraction of a millimeter. The samples were dried and weighed to obtain a mass $(m)$, and to calculate a mass per unit area $(M=m / A)$ and a deposit density $\left(\rho_{d}=M / T\right)$ at each location. Maps of both thickness (fig. $\left.1 G\right)$ and mass load (fig. $1 \mathrm{~A}$ ) were created by contouring these data.

Like new-fallen snow, these deposits were light and fluffy. Bulk deposit densities in central Washington and beyond averaged $450 \mathrm{~kg} / \mathrm{m}^{3}$ and decreased to less than $100 \mathrm{~kg} / \mathrm{m}^{3}$ beyond $500 \mathrm{~km}$ distance (Sarna-Wojcicki and others, 1981). Rainfall rapidly compacted the ash, as observed when sampling deposits from May 25 and June 12 eruptions, which were accompanied or shortly followed by rain and had densities of 1,000 to $1,250 \mathrm{~kg} / \mathrm{m}^{3}$ (Sarna-Wojcicki and others, 1981). Grainsize distributions were also analyzed from many samples, and then combined in a weighted sum to estimate the grain-size distribution of the entire erupted mass (Carey and Sigurdsson, 1982; Durant and others, 2009).

Several key findings were noted:

1. The overall grain-size distribution (fig. $2 G$ ) was exceedingly fine, with more than 60 percent of the erupted mass consisting of particles finer than 0.06 $\mathrm{mm}$ diameter. Beyond about $200 \mathrm{~km}$ distance, greater than 75 percent of ash was less then $0.06 \mathrm{~mm}$ diameter (Durant and others, 2009). Much of the fine ash consists of the walls of burst pumice bubbles. The fine grain size has been linked to both the bubble sizes in the magma (dominantly $0.01-0.022$ millimeters [mm] (Genareau and others, 2012)) and the milling of ash within pyroclastic flows (Dartevelle and others, 2002).

2. The median grain size of the ash decreased downwind to about $300 \mathrm{~km}$ distance, then remained constant at greater distance (Carey and Sigurdsson, 1982; Durant and others, 2009).

3. The grain-size distribution (GSD) at about $25-200 \mathrm{~km}$ distance was bimodal (fig. $2 A-C$ ). A coarse mode of particles a few tenths of a millimeter in diameter dominated at proximal distances (fig. $2 A, B$ ), but they decreased in both median size and in mass fraction with distance and disappeared from the size distribution beyond about $200 \mathrm{~km}$ (fig. 2D). A fine mode of particles with a median size of 8-16 micrometers did not change significantly in median size but increased in abundance with distance.

4. Isopach maps showed that both deposit thickness and mass load decreased with distance, but they then increased again to form an intriguing secondary maximum about $290 \mathrm{~km}$ downwind (fig. 1G), near the town of Ritzville, Washington (Sarna-Wojcicki and others, 1981). At this distance, about 93 percent of the tephra is smaller than $0.06 \mathrm{~mm}$. Particles of this size, falling from a 15-km-high plume, would not have deposited at this distance under these wind conditions if they were falling individually.

5. These observations indicate that the fine ash modes in figure $2 A-F$ fell as clusters, so that their fall velocity was independent of the size of individual particles. The increased ashfall near Ritzville suggests either that the clusters had a narrow range of fall velocities (0.66-0.78 m/s; (Mastin and others, 2016)), causing them to land at a similar location, or that there was a change in the ash cloud that led to rapid sedimentation once the plume reached Ritzville. These ash clusters could be observed during active fallout. In Pullman, Washington for example (390 km downwind), aggregates were captured on wet, painted cardboard and described as delicate clusters $0.25-0.5 \mathrm{~mm}$ in diameter, composed of particles from less than 0.001 to $0.04 \mathrm{~mm}$ in size (Sorem, 1982). Nearly all aggregates disintegrated on landing and left little evidence of their existence in the deposit.

The bulk volume of the May 18, 1980, deposit, was estimated at $1.1 \mathrm{~km}^{3}$ and was calculated by determining the area within each isopach line, multiplying each isopach area by the isopach thickness, and then summing (Sarna-Wojcicki and others, 1981). Using the measured average deposit density and assuming a magma density of 2,000-2,600 kg/ $\mathrm{m}^{3}$, Sarna-Wojcicki and others (1981) estimated the bulk tephra volume to be equivalent to about 0.20 to 0.25 cubic kilometers $\left(\mathrm{km}^{3}\right)$ of dense-rock-equivalent (DRE) magma. Later, the estimate was revised to $0.33 \mathrm{~km}^{3}$ (Criswell, 1987; Pallister and others, 1992).

\section{Older Tephra Deposits}

Field geologists, in the past five decades, have identified and named at least a dozen sets of tephra beds at Mount St. 

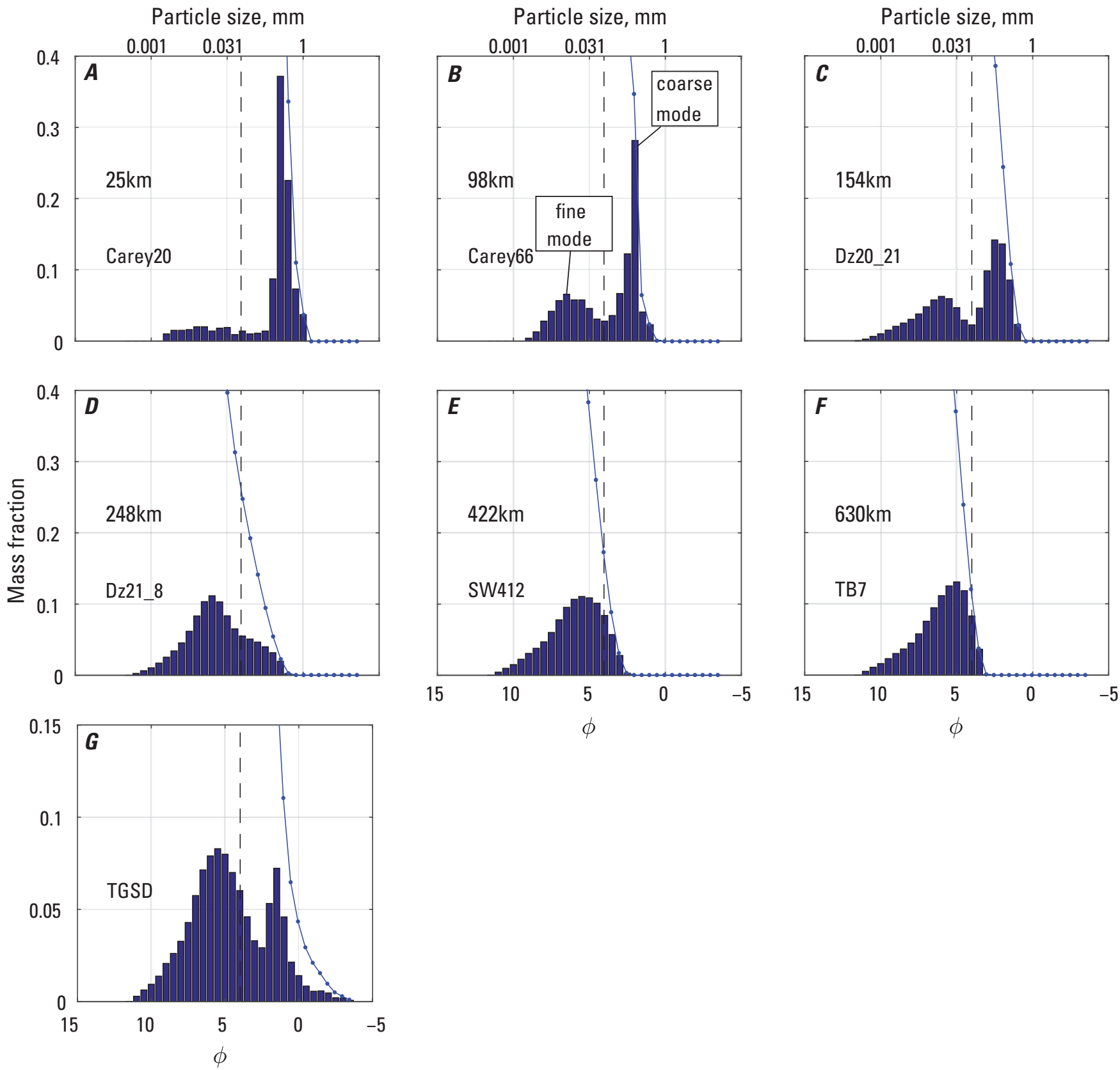

Figure 2. Graphs showing particle-size distributions of tephra-fall from the May 18, 1980, eruption at Mount St. Helens. $A-F$, Particle-size distributions of the deposit at different distances from the source, based on grain-size analyses published in Durant and others (2009). Names of samples analyzed are listed on the figure. Locations of these samples are shown in figure $1 A$. G, Total grain-size distribution (TGSD) for combined deposit. Blue bars give the mass fraction in a given bin. Blue lines with dots give the cumulative mass fraction coarser than the given size. Black dashed line is 0.063 millimeters $(\mathrm{mm})$. $\mathrm{km}$, kilometer. 
Helens (Mullineaux, 1986). Table 2 lists all the tephra deposits from large eruptions of Holocene age at MSH. All such eruptions occured during the Spirit Lake Stage, since 3.9 ka. Carey and others (1995) estimated that the size of these eruptions ranged from 0.1 to about $4 \mathrm{~km}^{3} \mathrm{DRE}$ (table 2). There are, however, large uncertainties in these estimates. To illustrate, figure $3 A$ shows the map of deposit thickness $(\mathrm{cm})$ used by Carey and others (1995) to estimate the volume of the largest Holocene tephra deposit, the $3.5 \mathrm{ka} \mathrm{Yn}$. Red dots indicate locations where thicknesses were measured. Contour lines of equal thickness (isopachs) are interpolations of the thickness measurements. Note that, for this prehistoric deposit, the isopachs are constrained by fewer field measurements than the 1980 deposit

(fig. 1A). The thinnest isopach in figure $3 A$ is $20 \mathrm{~cm}$ in contrast to $0.5 \mathrm{~mm}$ on the $1980 \mathrm{map}$ (fig. $1 G$ ). In addition, the Yn on map figure $4 A$ only extends about $40 \mathrm{~km}$ from of the volcano, in contrast to about $800 \mathrm{~km}$ on the 1980 map. Within $40 \mathrm{~km}$ distance, the 1980 deposit contained only about six percent of its total volume (Carey and others, 1995).

Deposit volume can be estimated by determining the area within each isopach line and plotting the log of the isopach thickness versus the square root of the area encompassed within each isopach line. For a well-mapped deposit like that of May 18, 1980, the data can be fit with two straight lines as shown, and the area under those lines can be integrated to give a bulk volume (fig. $3 B$ ).

Published Yn data define only the proximal line segment (red line, fig. 3C). Carey and others (1995) used published data from other deposits to argue that a distal line segment should intersect the proximal one at a point where thickness is about 12 percent of $T_{0}\left(T_{1}\right.$, fig. $\left.3 C\right)$; and the line should have a slope of about 0.01 to 0.015 . From this assumed second line (blue dashed line, fig. 3C), Carey and others (1995) estimated about $15 \mathrm{~km}^{3}$ bulk erupted volume, with an uncertainty of \pm 60 percent. Carey and others (1995) converted $15 \mathrm{~km}^{3}$ bulk erupted volume to $4 \mathrm{~km}^{3}$ DRE assuming a deposit density of $600 \mathrm{~kg} / \mathrm{m}^{3}$ and a magma density of $2,300 \mathrm{~kg} / \mathrm{m}^{3}$. Carey and others (1995) did not present the data used to derive the second line or show a plot like figure $3 C$ in their paper.

Recent work has revised the volume of most Mount St. Helens tephras downward. Nathenson (2017) plotted $\ln (T)$ versus $\operatorname{sqrt}(A)$ for $\mathrm{Yn}$ and noted that data points for the four isopach lines (black dots, fig. $3 \mathrm{C}$ ) followed the proximal trend line to a point well beyond $T_{1}$, where the distal line should intersect. Thus, Nathenson concluded that the Yn could not have the volume inferred by Carey and others (1995). Nathenson (2017) extrapolated the thicknesses using thinning trends (black lines, fig. 3C) from deposits documented by Sulpizio (2005). For each deposit in table 2, Nathenson (2017) estimated three volumes based on thinning trends in which less than 30 percent, 30-70 percent, or greater than 70 percent of the deposit lay within a proximal region of high thinning rates. For the Holocene eruptions in table 2, Nathenson's (2017) volumes are $0.008-2.3 \mathrm{~km}^{3} \mathrm{DRE}$ - much smaller than the $0.1-4.0 \mathrm{~km}^{3}$ of Carey and others (1995). Nathenson (2017) showed that Carey and others' (1995) volume estimates could not be derived using the methodology described in their paper. For this reason, we consider values of Nathenson (2017) to be more authoritative.

The Yn represents deposit from the largest eruption in the past 10,000 years from MSH, and we take it to be the largest (volumetrically) likely to occur for the purposes of our analysis. We call this volume $V_{\max }$ and use it as the maximum eruption volume modeled.

Volumes of tenths or hundredths of a cubic kilometer are several times more frequent than those of cubic kilometers (table 2). This trend is important in our modeling procedure and is described later.

Table 2. Tephra deposits from large Plinian eruptions of Holocene age at Mount St. Helens, Washington.

[For prehistoric eruptions, ages (column 2) are taken from Nathenson (2017). Columns 3-6 give approximate volumes of the deposits, as bulk tephra (columns 3 and 4), and dense-rock equivalent magma (DRE, columns 5 and 6). Volumes in columns 3 and 5 are from Carey and others (1995); those in 4 and 6 are revisions by Nathenson (2017). For the 1980 eruption, the erupted volume (DRE) of $0.3 \mathrm{~km}^{3}$ for the Plinian fall deposit is from Pallister and others (1992) Abbreviations: cal yrs B.P., calendar years before present (where present is 1950 C.E.); C.E., common era; DRE, dense-rock equivalent; km³, cubic kilometer; yr, year]

\begin{tabular}{|c|c|c|c|c|c|}
\hline \multirow[t]{2}{*}{ Deposit name } & \multirow[t]{2}{*}{ Age } & \multicolumn{2}{|c|}{ Bulk volume, in km³ } & \multicolumn{2}{|c|}{ DRE Volume, in $\mathbf{k m}^{3}$} \\
\hline & & Carey & Nathenson & Carey & Nathenson \\
\hline 1980 & 1980 C.E. & 1.1 & 1.1 & 0.3 & 0.3 \\
\hline We & 1482 C.E. & 1.5 & $0.15-0.80$ & 0.4 & $0.039-0.21$ \\
\hline Wn & 1479 C.E. & 7.7 & $0.71-1.4$ & 2.0 & $0.19-0.37$ \\
\hline Ps & 2550-2900 cal. yrs B.P. & 0.4 & $0.031-0.18$ & 0.1 & $0.008-0.047$ \\
\hline Ye & $3300-3500$ cal. yrs B.P. & 3.5 & $0.5-1.5$ & 0.9 & $0.13-0.39$ \\
\hline Yn & 3500 cal. yrs B.P. & 15.3 & $1.6-8.8$ & 4.0 & $0.78-2.3$ \\
\hline $\mathrm{Yb}$ & 3850-3900 cal. yrs B.P. & 1.2 & $0.044-0.26$ & 0.3 & $0.011-0.068$ \\
\hline
\end{tabular}


A. $\mathrm{Yn}$

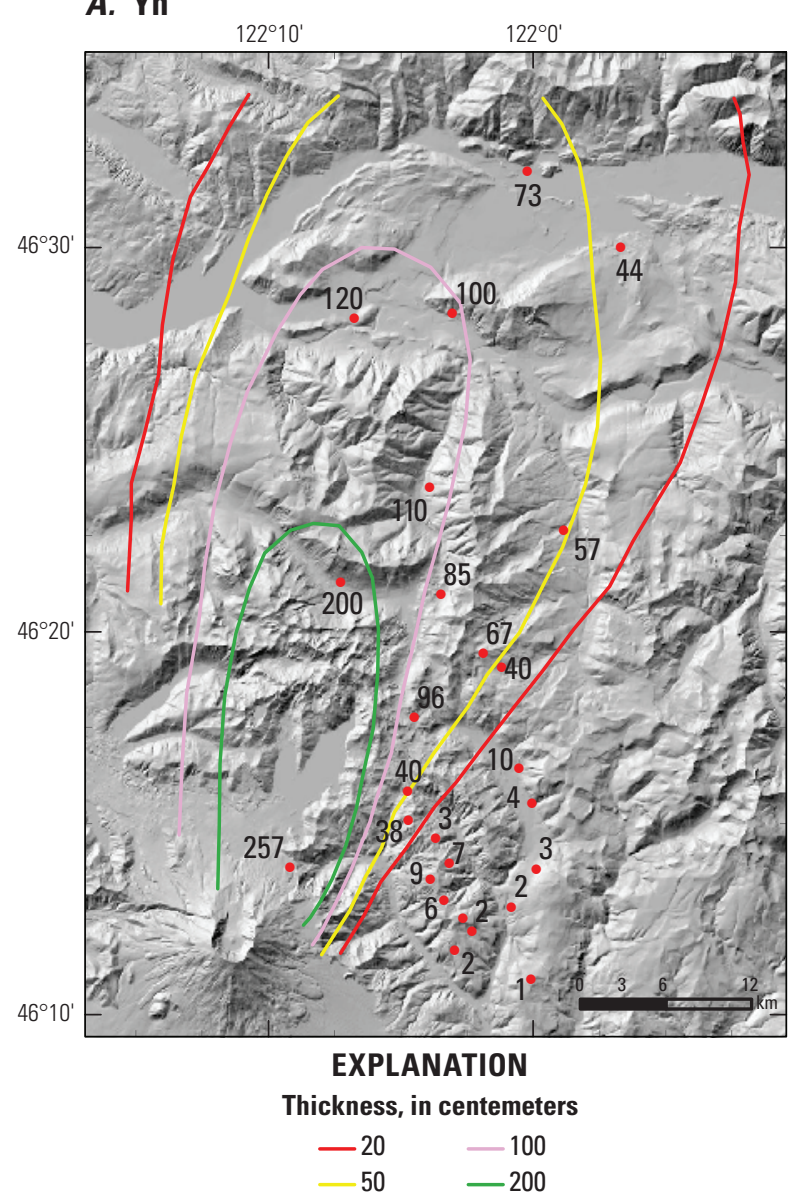

- Measurement
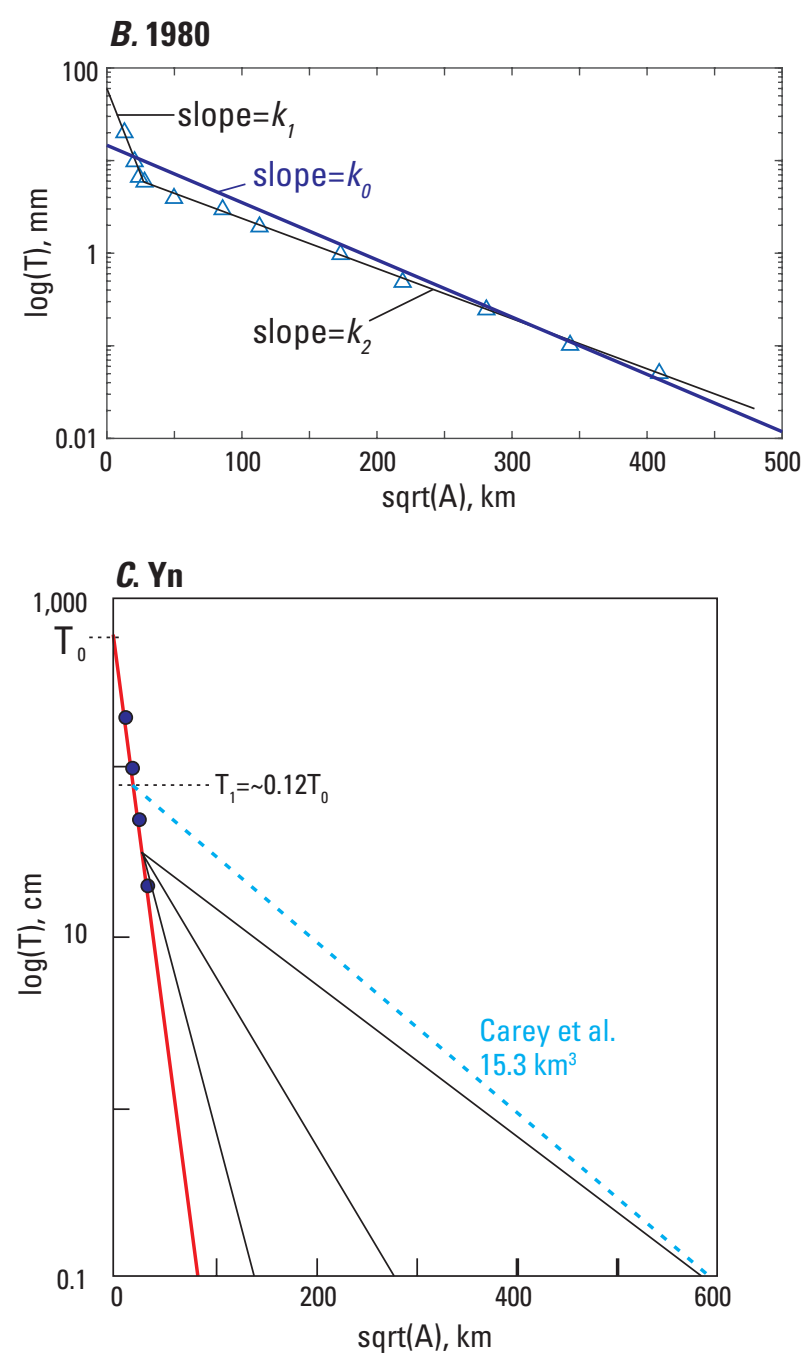

Figure 3. Map and graphs showing thickness of the Yn and 1980 deposits at Mount St. Helens. A, Measured thicknesses of the Yndeposit at Mount St. Helens and isopach contours of the thickness distribution, digitized from figure $3 A$ of Carey and others (1995). $B$, Plot of log thickness (T) versus square root (sqrt) of the area encompassed within each isopach line for the May 18, 1980, deposit (fig. 1G). C, Plot of log thickness versus square root of area within each isopach for the $\mathrm{Yn}$ deposit (fig. $3 A$ ). Blue dots are the area within isopach lines in figure $3 A$ (the lines had to be extrapolated to form closed polygons to derive these data points). Red line is the best-fit line through these points. Blue dashed line is the distal line inferred by Carey and others (1995) to derive a bulk tephra volume of 15.3 cubic kilometers $\left(\mathrm{km}^{3}\right)$. Black lines were distal lines inferred by Nathenson (2017) to derive his estimated tephra volumes. km, kilometer. 


\section{Methods}

To simulate tephra transport and deposition, we use the model Ash3d, developed by the U.S. Geological Survey (Schwaiger and others, 2012). Ash3d is an Eulerian, finite-volume, advection-diffusion model that divides the atmosphere into a three-dimentional grid of cells (fig. 4). In each cell, at each time step, atmospheric properties such as wind vectors, temperature and pressure are linearly interpolated from the nearest cells in a numerical weather prediction model.

The column of cells above the volcano (fig. $4 B$ ) act as source nodes, meaning that at each time step, a mass of ash is added to each node and distributed vertically using the following equation (Suzuki, 1983), with an adjustable constant $k$ that modulates the degree to which mass is concentrated near the top of the column:

$$
\frac{d Q_{m}}{d z_{v}}=Q_{m} \frac{k^{2}\left(1-z / H_{v}\right) \exp \left(k\left(z_{v} / H_{v}-1\right)\right)}{H_{v}[1-(1+k) \exp (-k)]}
$$

where

$$
\begin{gathered}
Q_{m} \quad \text { is the mass eruption rate (kilograms per } \\
\text { second [ } \mathrm{kg} / \mathrm{s}] \text { ), } \\
H_{v} \quad \text { is plume height above the vent; and } \\
z_{v} \quad \text { is elevation (above the vent) within the plume. }
\end{gathered}
$$

Within each cell, at a given time step, Ash3d calculates the flux through cell walls as tephra is: (1) advected by wind,
(2) settles by gravity, and (3) spreads by turbulent diffusion. Advection and settling are calculated through the Donor-Cell Upwind method using a Lax-Wendroff scheme (LeVeque, 2002, Chapter 6) in which flux in each direction is calculated sequentially (dimension splitting). Diffusion is calculated using an implicit Crank-Nicolson method in each coordinate to keep time steps reasonable (Schwaiger and others, 2012). Diffusion rates are calculated using a specified diffusion constant $K_{x}$. The calculations are done sequentially for each of a series of grain-size classes. These size classes represent individual particle sizes, or aggregates of particles. Particles or aggregates are assumed to be ellipsoidal in shape, with a specified diameter $d$, density $\rho$, and shape factor $F \equiv(b+c)$ / $2 a$, where $a, b$, and $c$ are the semi-major, intermediate, and semi-minor axes of an ellipsoid, respectively. The diameter $d$ is assumed to equal $(a+b+c) / 3$, and the volume is assumed to equal $\pi d^{3} / 6$. The settling rate of particles or aggregates is calculated using relations of Wilson and Huang (1979).

\section{Inputs}

We define four categories of model inputs. The first category consists of eruption source parameters as conventionally defined in Mastin and others (2009), such as, erupted volume $(V)$, plume height $(H)$, duration $\left(D_{e}\right)$, and a GSD characterized by parameters defined later. The source parameters differ from one simulation to the next, using

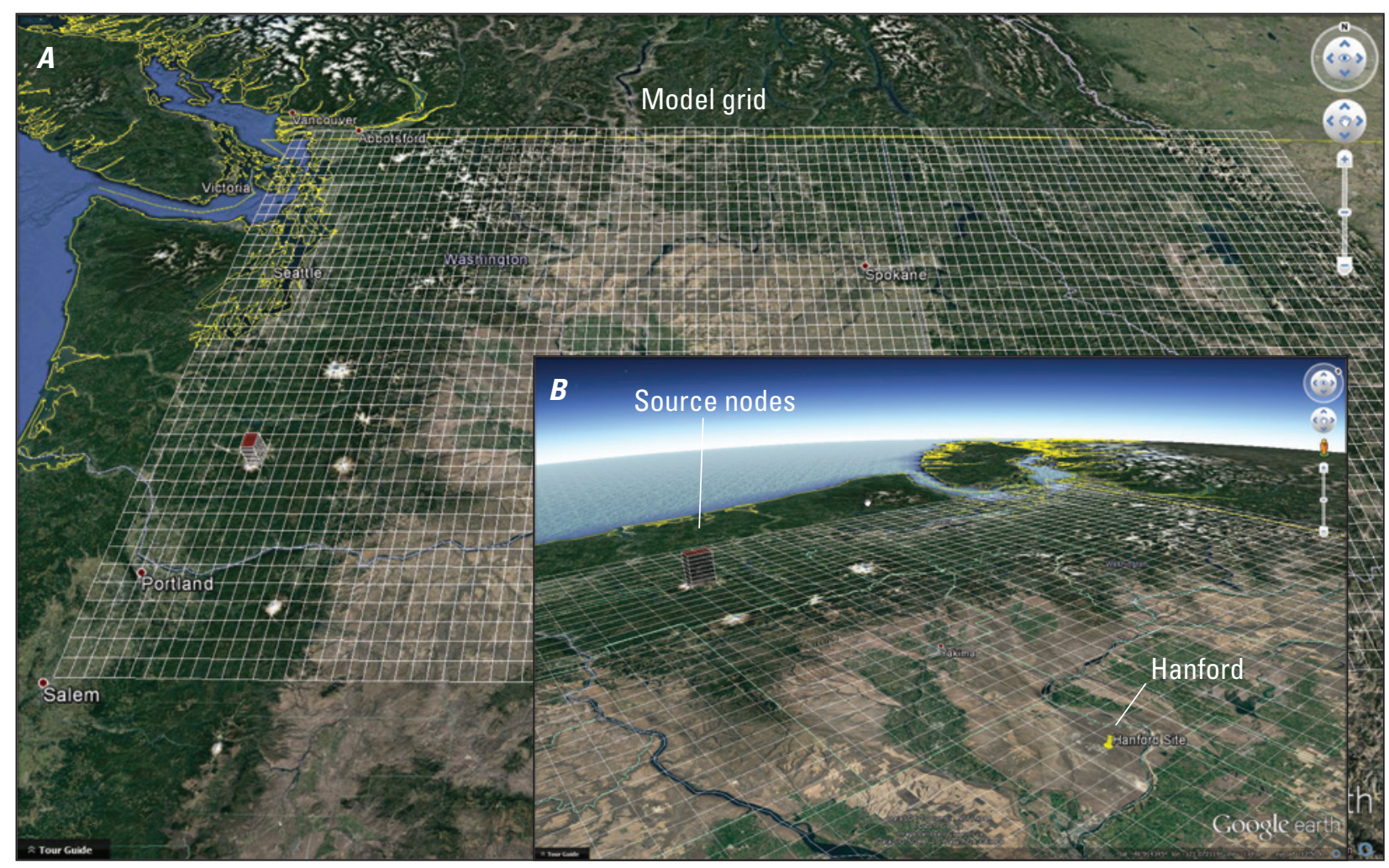

Figure 4. Model grid used by the Ash3d model for simulations. $A$, Full view of the model grid. $B$, Close-up of the grid in southern Washington State, highlighting the source nodes above Mount St. Helens, and the Hanford, Washington site. Grid spacing is $0.1^{\circ}$ latitude and longitude. 
procedures described below and summarized in table 3. Many of the parameter assignments involve randomly selecting the value of a variable from within a probability density function (pdf). The types of pdfs we use are uniform (fig. $5 A$ ) in which the probability of a given value is equal within a min-max range; and Gaussian (fig. 5B), in which the probability is highest at a mean value and decreases at a rate defined by the standard deviation.

The second category includes secondary physical parameters such as the Suzuki constant $k$; particle shape factor $F$; densities of particles $\left(\rho_{p}\right)$, the deposit $\left(\rho_{d}\right)$, and magma $\left(\rho_{m}\right)$; and the diffusion coefficient $K_{x}$. These parameters do not vary between simulations. Rather, we use values that have been found to accurately reproduce mapped deposits in other studies (table 4). The third category consists of meteorological parameters: the wind field, atmospheric pressure, and temperature, which are used to calculate particle advection and fall velocities. These values are obtained from the output of an external meteorological model. The fourth category includes model settings such as vertical and horizontal cell spacing, which have been adjusted to give an acceptable balance between model accuracy and speed.

Table 3. Summary of procedures used to assign eruption source parameters in each simulation.

[Abbreviations: DRE, dense-rock equivalent; km, kilometer; $\mathrm{km}^{3}$, cubic kilometer; mm, millimeter; pdf, probability density function; $\rho_{m}$, density of magma; $Q_{m}$, mass eruption rate]

\begin{tabular}{|c|c|}
\hline Parameter & Method of assignment \\
\hline Erupted volume $(V)$ & We choose randomly from a uniform pdf on a log scale, extending from $V_{\min }=0.008$ to $V_{\max }=2.3 \mathrm{~km}^{3} \mathrm{DRE}$. \\
\hline Plume height $\left(H_{v}\right)$ & $\begin{array}{l}\text { We calculate } H_{v} \text { from } V \text { using equation } 3 \text {, and then add a random value, sampling from a Gaussian pdf with a mean } \\
\text { of zero and a standard deviation of } 2.9 \mathrm{~km} \text {. }\end{array}$ \\
\hline Eruption Duration $\left(D_{e}\right)$ & $\begin{array}{l}\text { We calculate the eruption rate from the plume height using equation } 2 \text {, and then calculate the duration by } \\
\text { converting erupted volume to mass (assuming } \rho_{m}=2,500 \mathrm{~kg} / \mathrm{m}^{3} \text { ) and dividing by the rate } Q_{m} \text {. }\end{array}$ \\
\hline Grain-size distribution & $\begin{array}{l}\text { We assume that all fine ash aggregates and characterize the fine ash fraction using two adjustable parameters, its } \\
\text { fraction of the erupted mass }\left(m_{\text {fines }}\right) \text { and the size of aggregates }\left(\mu_{\text {agg }}\right) \text {. We choose } m_{\text {fines }} \text {, from a Gaussian pdf that } \\
\text { has a mean of } 0.5 \text { and standard deviation of } 0.15 \text {, based on considerations explained in the text. We choose } \\
\mu_{\text {agg }} \text { from a Gaussian pdf having a median of } \phi=2.4(0.189 \mathrm{~mm}) \text { and a standard deviation of } \phi=0.1 \text { ( } \pm 7 \text { percent). } \\
\text { The aggregates are divided into five bins with mass fractions as shown in table } 6 \text { for median aggregate size } \\
\sigma_{a g g}=0.1 \phi . \text { For particles that do not aggregate, we use sizes and mass fractions derived from the May } 18,1980 \text {, } \\
\text { deposit (Durant and others, 2009), with two modifications: }(1) \text { we consolidate particles greater than } 2 \mathrm{~mm}, \\
\text { which generally deposit at less than } 100 \mathrm{~km} \text { distance, into a single } d=2 \mathrm{~mm} \text { size bin; and (2) we adjust the mass } \\
\text { fraction in each bin equally so that the sum in all these bins, plus } m_{\text {fines }}, \text { equals } 1 .\end{array}$ \\
\hline
\end{tabular}

\section{A. Uniform pdf}

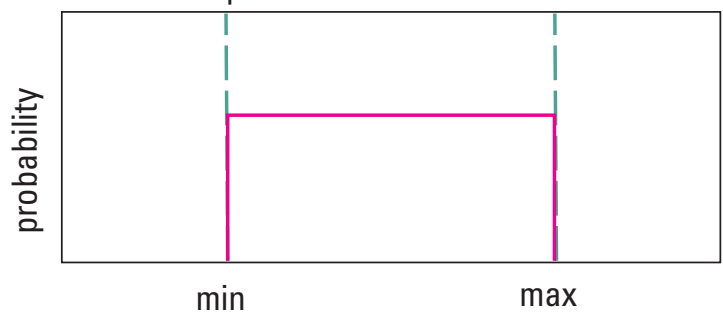

B. Gaussian pdf

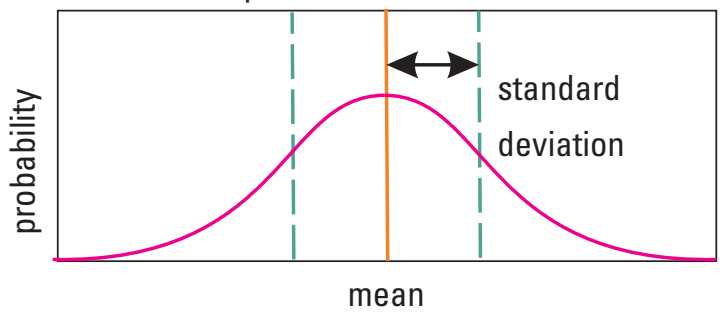

Figure 5. Illustration of the two types of probability density functions (pdf's) used to assign parameter values in this study: uniform $(A)$ and Gaussian $(B)$.
Table 4. Values of secondary physical parameters and model settings used in each simulation.

[Abbreviations: asl, above sea level; $\mathrm{kg} / \mathrm{m}^{3}$, kilogram per cubic meter; $\mathrm{km}$, kilometer]

\begin{tabular}{ll}
\hline Physical Parameter or setting & \multicolumn{1}{c}{ Value } \\
\hline Model domain & $\begin{array}{l}45-49^{\circ} \mathrm{N} \\
123-113^{\circ} \mathrm{W}\end{array}$ \\
& $\begin{array}{c}0-35 \mathrm{~km} \text { asl }(30 \text { percent higher } \\
\text { than plume })\end{array}$ \\
& $122.18^{\circ} \mathrm{W}$ \\
& $46.2^{\circ} \mathrm{N}$ \\
\hline Vent location & $2.00(\mathrm{~km})$ \\
\hline Vent elevation & $0.1^{\circ} \mathrm{horizontal}$ \\
\hline Nodal spacing & $2.0 \mathrm{~km}$ vertical \\
& 0 \\
\hline Diffusion coefficient $\left(K_{x}\right)$ & 8 \\
\hline Suzuki constant $(k)$ & 0.44 \\
\hline Particle shape factor $(F)$ & $1,000 \mathrm{~kg} / \mathrm{m}^{3}$ \\
\hline Deposit density $\left(\rho_{d}\right)$ & $2,500 \mathrm{~kg} / \mathrm{m}^{3}$ \\
\hline Magma density $\left(\rho_{m}\right)$ & 1.00 \\
\hline Aggregate shape factor $(F)$ & \\
\hline
\end{tabular}




\section{Eruption Source Parameters}

We ran approximately 10,000 Ash3d simulations using a modified Monte Carlo approach. We did not use a straight Markov Chain Monte Carlo method, in which all key inputs are randomly assigned, independently of the others, because some inputs were correlated. For example, larger-volume eruptions tend to have higher plumes, and longer durations. Below, we explain how these relations are considered.

\section{Erupted Volume}

We choose volume $(V)$ from a uniform pdf on a log scale ranging from $0.008-2.3 \mathrm{~km}^{3} \mathrm{DRE}$ - the range estimated by Nathenson (2017); table 2) for Holocene Mount St. Helens eruptions. Eruptions smaller than $0.008 \mathrm{~km}^{3}$ are unlikely to impact the Hanford site. Our choice of a log scale implies that $0.1 \mathrm{~km}^{3}$ eruptions are about 10 times as likely as $1 \mathrm{~km}^{3}$ eruptions and reflects the greater frequency of small eruptions in the Holocene record.

\section{Plume Height}

Larger-volume eruptions produce higher plumes. On May 18, 1980, for example, Mount St. Helens erupted ash for about 9 hours at an average rate of $2 \times 10^{7} \mathrm{~kg} / \mathrm{s}$ (Carey and Sigurdsson, 1985). The Plinian phase (after 9:00 a.m.) produced a plume that fluctuated around $14 \mathrm{~km}$ above the vent (Harris and others, 1981). The much larger June 15, 1991, eruption of
Mount Pinatubo in the Philippines expelled close to $1 \times 10^{9} \mathrm{~kg} / \mathrm{s}$ of magma for several hours (Koyaguchi and Tokuno, 1993), producing a maximum height of 34-39 km above the vent (Holasek and others, 1996). The smaller Eyjafjallajökull eruption in Iceland on April 14-18, 2010, emitted an average mass rate of $5-10 \times 10^{5} \mathrm{~kg} / \mathrm{s}$ (Gudmundsson and others, 2012) and produced plume heights about $4-8 \mathrm{~km}$ above the vent (Arason and others, 2011).

Historical eruption data illustrate this relationship.

Because big eruptions produce higher plumes than small ones, the plume height for each simulation cannot be chosen independently from erupted volume. Data have been published for a few dozen recent eruptions for which average plume height, erupted mass, and duration have been recorded (Wilson and others, 1978, table 3; Sparks and others, 1997, table 5.1; Mastin and others, 2009, table 1). The correlation observed in equation 2 is based on a few dozen examples (fig. 6A; (Mastin and others, 2009):

$$
H_{v}=0.3 Q_{m}^{0.241}
$$

where

$$
\begin{aligned}
& H_{v} \quad \begin{array}{l}
\text { is the plume height in kilometers above the } \\
\text { vent; and }
\end{array} \\
& Q_{m} \quad \text { is the mass eruption rate, in } \mathrm{kg} / \mathrm{s} .
\end{aligned}
$$

The best-fit exponent of 0.241 is similar to a theoretical prediction of 0.25 (Morton and others, 1956) and to previous empirical relations (Wilson and others, 1978, eq. 2; Sparks and others, 1997, eq. 5.1).

Table 5. Total grain-size distribution from the 1980 deposit (column 3) and used in this study (column 4).

[Mass fractions in column 3 are estimated by Durant and others (2009, supplementary file number 3 of their paper) by integrating the deposit to a distance of

\begin{tabular}{|c|c|c|c|c|}
\hline \multirow[t]{2}{*}{ Size of particles, in $\phi$} & \multirow{2}{*}{ Diameter, in mm } & \multicolumn{2}{|c|}{ Mass Fractions } & \multirow[t]{2}{*}{ Density of particles, in $\mathrm{kg} / \mathrm{m}^{3}$} \\
\hline & & 1980 & $\mathrm{~m}_{\mathrm{p}, \mathrm{i}}$ (this study) & \\
\hline$\leq-4.0$ & 16.0000 & & & \\
\hline-3.5 & 11.3137 & 0.0007 & & 490 \\
\hline-3.0 & 8.0000 & 0.0019 & & 490 \\
\hline-2.5 & 5.6569 & 0.0021 & & 490 \\
\hline-2.0 & 4.0000 & 0.0047 & & 665 \\
\hline-1.5 & 2.8284 & 0.0058 & & 1,292 \\
\hline-1.0 & 2.0000 & 0.0056 & $0.0727\left(1-m_{\text {fnes }}\right)$ & 2,003 \\
\hline-0.5 & 1.4142 & 0.0084 & $0.0294\left(1-m_{\text {fines }}\right)$ & 2,350 \\
\hline 0.0 & 1.0000 & 0.0141 & $0.0493\left(1-m_{\text {fines }}\right)$ & 2,005 \\
\hline 0.5 & 0.7071 & 0.0214 & $0.0748\left(1-m_{\text {fnes }}\right)$ & 2,248 \\
\hline 1.0 & 0.5000 & 0.0459 & $0.1605\left(1-m_{\text {fines }}\right)$ & 2,624 \\
\hline 1.5 & 0.3536 & 0.0723 & $0.2528\left(1-m_{\text {fines }}\right)$ & 2,644 \\
\hline 2.0 & 0.2500 & 0.0532 & $0.1860\left(1-m_{\text {fines }}\right)$ & 2,639 \\
\hline 2.5 & 0.1768 & 0.0292 & $0.0766\left(1-m_{\text {fines }}\right)$ & 2,706 \\
\hline
\end{tabular}
about 670 kilometers. Column 4 gives formulas used to calculate $m_{p, i}$ if $m_{\text {fines }}$ is known. Density values are calculated as described in the text. Size of particles $(\phi)$ is $-\log _{2}(d)$, where $d$ is particle diameter in millimeters. Abbreviations: $\mathrm{kg} / \mathrm{m}^{3}$, kilogram per cubic meter; mm millimeter; $\mathrm{m}_{\mathrm{p}, \mathrm{i}}$, mass fraction of nonaggregating particles of size class i] 
Table 5. Total grain-size distribution from the 1980 deposit (column 3) and used in this study (column 4).—Continued

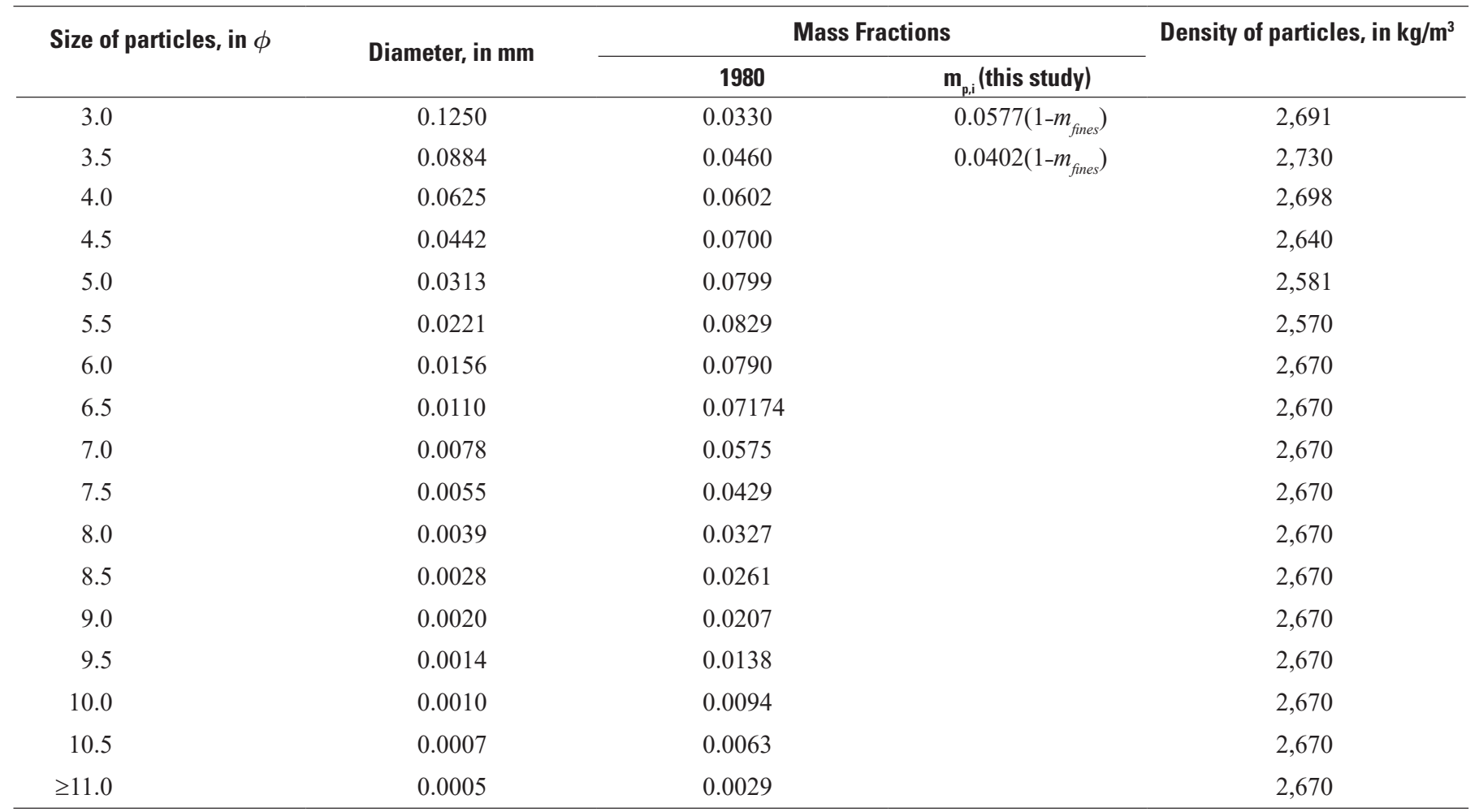
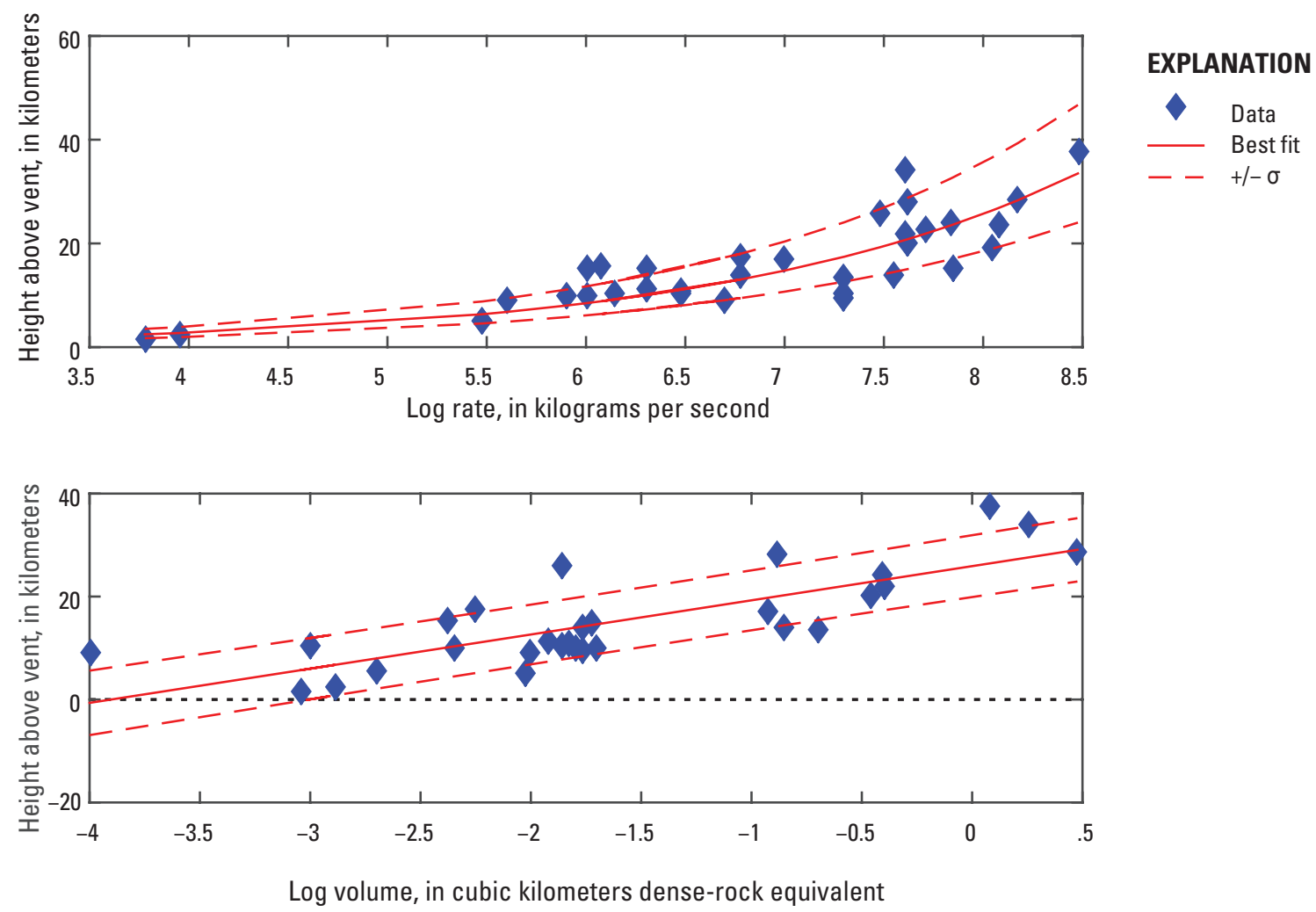

Figure 6. Correlations between plume height and eruption rate or erupted volume. $A$, Plume height above the vent (kilometers) versus log of eruption rate (kilograms per second) using historical data tabulated in Mastin and others (2009) (blue diamonds). The red solid line is a best-fit curve through these data, and the dashed lines give the $\pm 1 \sigma$ standard error in prediction. $B$, Plume height above the vent versus total erupted volume (cubic kilometers $\left[\mathrm{km}^{3}\right]$ dense rock equivalent [DRE]) for the same historical eruptions. 
Total erupted volume also correlates with plume height (Carey and Sigurdsson, 1989; Mastin and others, 2009, Table 1). A best-fit curve through historical data (fig. 6B) gives:

$$
H_{\text {bestfit }}=25.9+6.64 \cdot \log _{10}(V)
$$

where

$$
\begin{aligned}
& \mathrm{H}_{\text {bestfit }} \quad \text { is plume height above the vent; and } \\
& V \text { is erupted volume in } \mathrm{km}^{3} \text { DRE. The standard } \\
& \text { error in prediction }(1 \sigma) \text { based on this } \\
& \text { correlation is about } 5.8 \mathrm{~km} \text {. }
\end{aligned}
$$

We assign plume height using relationship (3), but then add a random number using a Gaussian pdf with a mean of zero and standard deviation of $2.9 \mathrm{~km}$ - half the standard error in the regression. We arbitrarily reduced the standard deviation of the Gaussian adjustment from 5.8 to $2.9 \mathrm{~km}$ to avoid having negative plume heights near the low end, and unrealistically high plumes (higher than $45 \mathrm{~km}$ ) at the high end.

\section{Grain-Size Distribution}

The grain-size distribution (GSD) is challenging to parameterize because several processes can accelerate the fallout of fine ash; including particle aggregation, scavenging by rainfall, and bulk instabilities in the cloud (fig. 7). The Ash3d model does not explicitly account for these processes. Rather, we empirically adjust the input GSD, so fine ash is represented as aggregates of given size, shape, and density.

Our method to characterize distribution of both particles and aggregates in each simulation involves three groups of parameters: (1) one-dimensional arrays of the mass fractions $\left(m_{p, i}\right)$ of particles too large to aggregate, along with their size $\left(\phi_{\mathrm{p}, \mathrm{i}}\right)$ and density $\left(\rho_{p, i}\right)$; and single parameters defining $(2)$ the median aggregate diameter $\left(\mu_{a g g}\right)$, and (3) the mass fraction of fine, aggregating ash erupted $\left(m_{\text {fines }}\right)$.

\section{Non-Aggregating Particles}

To assign $m_{p, i}$, we start with mass fractions of each size $\phi_{\mathrm{p}, \mathrm{i}}$ from the 1980 deposit (table 5, column 3). We assign densities $\left(\rho_{p, i}\right)$ to each size fraction using measured proportions of mafic crystals, feldspar, lithics, pumice, and glass fragments (Carey and Sigurdsson, 1982), assuming a density of $3,200 \mathrm{~kg} / \mathrm{m}^{3}$ for mafic crystals, $2,600 \mathrm{~kg} / \mathrm{m}^{3}$ for feldspars, $2,900 \mathrm{~kg} / \mathrm{m}^{3}$ for lithics, $490 \mathrm{~kg} / \mathrm{m}^{3}$ for large pumice $(\phi \leq 1)$ (Klug and Cashman, 1994), and 2,670 kg/m $\mathrm{m}^{3}$ for small glass fragments $(\phi \geq 4.5)$. For intermediate-sized pumice or glass $(1<\phi<4.5)$, the density was interpolated linearly between 490 and $2,670 \mathrm{~kg} / \mathrm{m}^{3}$.

Next, we consolidate all particles larger than $2 \mathrm{~mm}$ in diameter into a single $2 \mathrm{~mm}$ bin, dramatically speeding computation time. Particles larger than $2 \mathrm{~mm}$ diameter will almost certainly fall out upwind of Hanford. Under the wind and plume conditions of 1980 , for example, nearly all particles larger than $0.25 \mathrm{~mm}$ diameter would have fallen out upwind (fig. 8A).

\section{Mean Aggregate Size $\left(\mu_{\text {agg }}\right)$}

Third, we divide $m_{\text {fines }}$ into five aggregate classes having a narrow Gaussian size distribution with a standard deviation $\sigma_{\text {agg }}=0.1 \phi$ (table 6). The narrow $\sigma_{\text {agg }}$ is justified by recent Ash3d modeling (Mastin and others, 2016) that optimally fits deposits of four well-documented eruptions with nearly the identical aggregate-size distributions (mean $\mu_{\text {agg }}=2.4 \pm 0.1 \phi$, standard deviation $\sigma_{a g g} \leq 0.1 \phi$ ). These eruptions-Mount St. Helens (May, 18, 1980); Crater Peak, Mt. Spurr, Alaska (September, 16-17, 1992); Ruapehu, New Zealand (June, 17, 1996); and Redoubt, Alaska (March, 23, 2009)_ranged widely in magma type, plume height, eruptive volume, mass fraction fine ash, and atmospheric temperature and water content, suggesting that these parameters are robust.

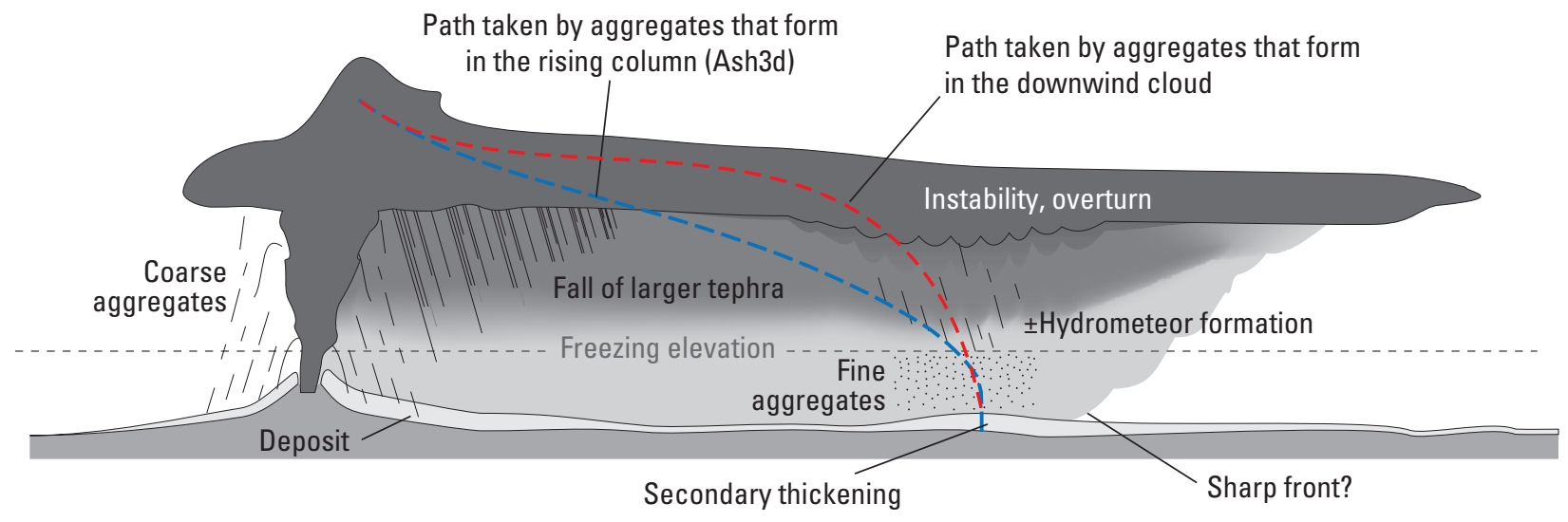

Figure 7. Diagram showing processes that influence the distribution of fine, distal ash. These include development of gravitational instability and overturn within the downwind cloud (Carazzo and Jellinek, 2012), and the development of hydrometeors as descending ash approaches the freezing elevation (Durant and others, 2009). 
Although $\mu_{\text {agg }}$ is tightly constrained, we vary it slightly between simulations by sampling from a pdf having a mean of $2.4 \phi$ and standard deviation of $0.1 \phi$.

\section{Mass Fraction Aggregating Ash}

The mass fraction of aggregating ash $\left(m_{\text {fines }}\right)$ was very high in the 1980 deposit, altering the pattern of fallout and contributing to the secondary maximum in thickness near Ritzville (Carey and Sigurdsson, 1982). But $m_{\text {fines }}$ almost certainly will vary in future MSH eruptions. If we define $m_{\text {fines }}$ to contain all ash of $\phi \geq 4$ ( $d \leq 0.063 \mathrm{~mm})$, and 75 percent, 50 percent, and 25 percent, respectively, of size bins $\phi=3.5,3$, and 2.5 (following Mastin and others (2016)), then $m_{\text {fines }}$ in the 1980 deposit is about 0.7 (table 5, column 3 ). The fraction smaller than $0.063 \mathrm{~mm}\left(m_{63}\right)$ in the 1980 deposit is about 0.6.

Recent research suggests that $m_{\text {fines }}$ may increase in future events with eruption size, magma silica content, and the size and abundance of pyroclastic flows (Rose and Durant, 2009) Mastin and others, 2009). However, these relations are hard to document in historical events. Consider silica content for example. Rose and Durant (2009) found $m_{63}$ (a proxy for $m_{\text {fines }}$ ) to be at least 0.3 in several silicic deposits, but $m_{63}$ was only $0.08-0.12$ in the silicic 2011 Cordon Caulle eruption (Bonadonna and others, 2015a). Another consideration is eruption size. Among the eruptions in table $7, m_{63}$ in the two largest ranges widely from $0.08-0.12$ (Cordon Caulle) to 0.6 (MSH). Entries in table 7 support the notion that pyroclastic flows (pf) generate fine ash, with $m_{63} \geq 0.4$ among the three pf-producing eruptions at MSH and Spurr. Still, the small dataset prevents us from extracting robust relationships.

In the absence of better data, we still lean toward the notion that future MSH eruptions will produce substantial quantities of fine ash. MSH eruptions tend to be large, silicic, and in the past have involved much pyroclastic-flow activity. If $m_{\text {fines }}$ in 1980 was 0.7 , we doubt it will be 0.1 in the next eruption. But the uncertainty is large, and the high $m_{63}$ content in 1980 (relative to other eruptions) suggests $m_{\text {fines }}$ may be lower in the future. Thus, for model simulations, we assign $m_{\text {fines }}$ using a Gaussian pdf with a mean of 0.5 and a standard deviation of 0.15 .

Table 6. Mass fraction of fine ash assigned to different size bins for aggregates.

[Abbreviations: $\mu_{\text {agg }}$ median aggregate size; $m_{\text {fnes }}$, mass fraction of a deposit moved into the aggegate size classes]

\begin{tabular}{cccccc}
\hline & $\mu_{\text {agg }} \mathbf{- 0 . 2 \phi}$ & $\mu_{\text {agg }} \mathbf{- 0 . 1 \phi}$ & $\mu_{\text {agg }}$ & $\mu_{\text {agg }} \mathbf{+ 0 . 1 \phi}$ & $\mu_{\text {agg }} \mathbf{+ 0 . 2 \phi}$ \\
\hline Fraction & $0.06 \mathrm{~m}_{\text {fines }}$ & $0.24 \mathrm{~m}_{\text {fines }}$ & $0.40 \mathrm{~m}_{\text {fines }}$ & $0.24 \mathrm{~m}_{\text {fines }}$ & $0.06 \mathrm{~m}_{\text {fines }}$ \\
\hline
\end{tabular}

Table 7. Mass fraction $\left(m_{63}\right)$ of fine (smaller than $0.063 \mathrm{~mm}$ ) ash in selected recent eruption deposits.

[Entries are in order of decreasing erupted volume ( $V$, in dense-rock equivalent). $\mathrm{SiO}_{2}$ refers to the weight percent $\mathrm{SiO}_{2}$ in the melt, a proxy for magma viscosity. " $V$ " refers to the erupted volume, in cubic kilometers $\left(\mathrm{km}^{3}\right)$ dense-rock equivalent (DRE). Pf? indicates whether pyroclastic flows occurred during this eruption which could have milled fine ash. Max. dist. is maximum distance in kilometers (km) from the vent of the most distal sample used to calculate the total grain-size distribution]

\begin{tabular}{|c|c|c|c|c|c|}
\hline Deposit & $\mathrm{SiO}_{2} \mathrm{wt} \%$ & $\mathbf{V ~ k m}^{3}$ & Pf? & $m_{63}$ & Max. dist. km \\
\hline Cordon Caulle, 2011, & 72 & 0.24 & & $0.08-0.12$ & 100 \\
\hline Mount St. Helens, $1980^{3,4}$ & 70 & 0.2 & $\mathrm{x}$ & 0.6 & 630 \\
\hline Fuego, $1974^{5,6}$ & 54 & 0.02 & & 0.03 & 150 \\
\hline Spurr, August 18,1992 & $60-75$ & 0.015 & $\mathrm{x}$ & 0.4 & 370 \\
\hline Spurr, September $17-18,1992^{7,8}$ & $60-75$ & 0.015 & $\mathrm{x}$ & 0.4 & 385 \\
\hline Redoubt, March 23, 20099,10 & 68 & 0.0016 & & 0.27 & 300 \\
\hline Ruapehu, $1996^{11,12}$ & $62-65$ & 0.001 & & 0.03 & 180 \\
\hline
\end{tabular}

\footnotetext{
${ }^{1}$ Bonadonna and others (2015b)

${ }^{2}$ Castro and others (2013)

${ }^{3}$ supplemental file number 3 in Durant and others (2009)

${ }^{4}$ Rutherford and others (1985)

${ }^{5}$ Rose and others (2008)

${ }^{6}$ Roggensack (2001)

${ }^{7}$ Durant and Rose (2009)

${ }^{8}$ Nye and others (1995)

${ }^{9}$ Mastin and others (2013)

${ }^{10}$ Coombs and others (2013)

${ }^{11}$ Bonadonna and Houghton (2005)

${ }^{12}$ Nakagawa and others (1999).
} 


\section{Secondary Physical Parameters}

The following physical parameters are assigned nonchanging values that have been found to optimally fit mapped deposits:

- Suzuki constant $(k)$. This parameter, which is used in equation 1 , controls the vertical distribution of mass in the source nodes (fig. $4 B$ ). Higher values of $k$ (for example $k \gtrsim 8$ ) concentrate most of the mass in the upper 20 percent or so of the column. A top-heavy column produces a prominent, realistic secondary thickening of the deposit but also produces an unrealistic decrease in the proximal deposit thickness (fig. 8 of Mastin and others [2016]). We chose a value of $k=8$ to balance these two features.
- Particle shape. We use the drag coefficient formula of Wilson and Huang (1979) to calculate settling velocity, assuming particles settle at their terminal velocity. Wilson and Huang (1979) approximate particles as ellipsoids with a shape factor $F=(b+c) / 2 a$, where $a, b$, and $c$ are the semi-major, intermediate, and semiminor axes of the ellipsoids, respectively. Wilson and Huang (1979) measured these axes dimensions for a collection of volcanic ash particles. We use a shape factor of 0.44 , which corresponds to the average of their measured values. We assume aggregates are round, consistent with previous work (Mastin and others, 2016). Aggregate shape strongly influences the depositional pattern, especially at distances of greater than $100 \mathrm{~km}$ (fig. 6 of Mastin and others [2016]).

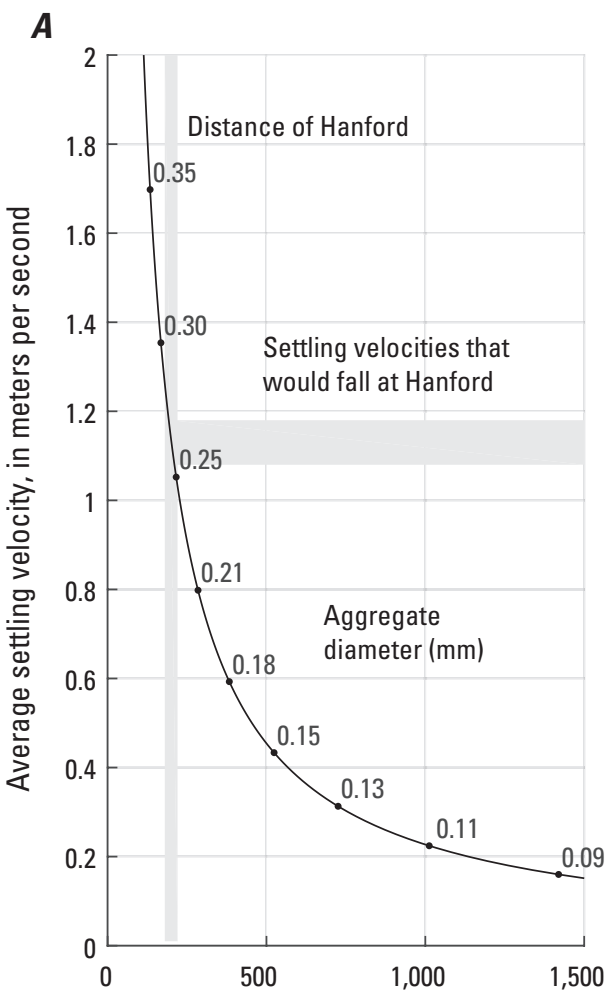

Transport distance, in kilometers
$\boldsymbol{B}$

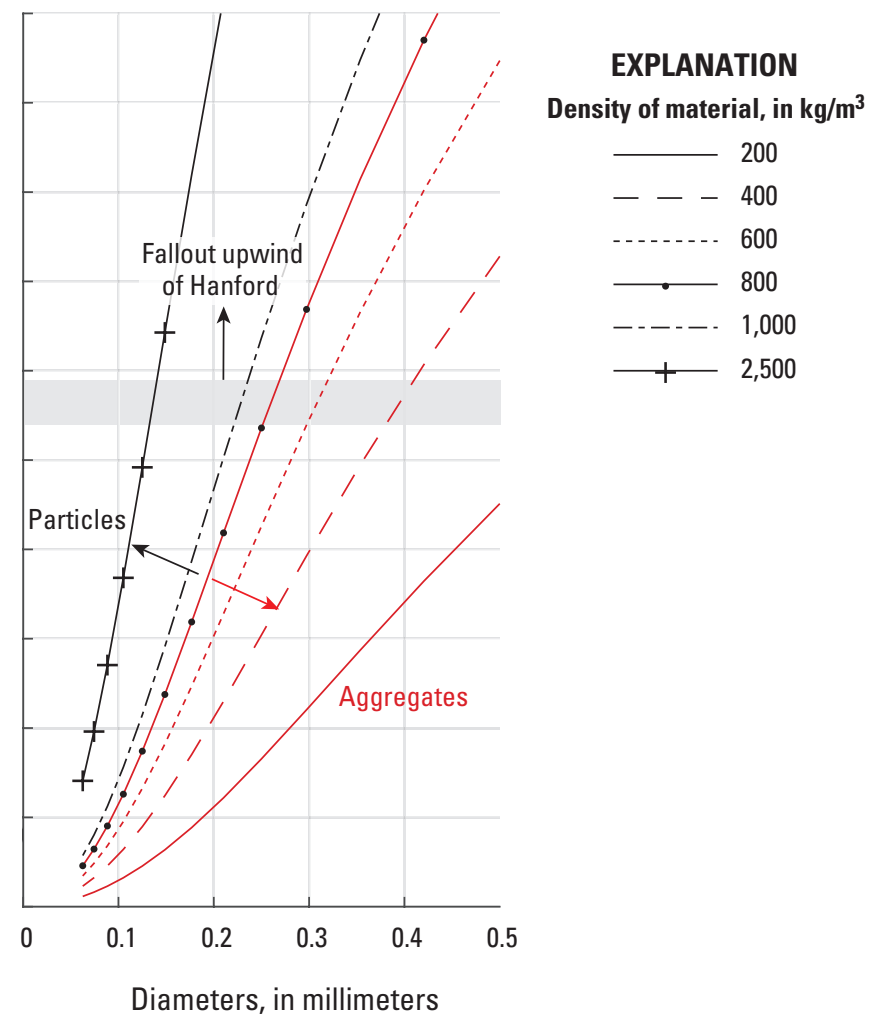

Figure 8. Graphs showing settling velocity versus transport distance and diameter for particulate matter falling at Hanford, Washington. A, Transport distance versus average fall velocity, assuming a 15.1 meters per second $(\mathrm{m} / \mathrm{s})$ wind speed, equal to the average wind speed at Mount St. Helens between 0 and 15 kilometer $(\mathrm{km})$ elevation on May 18, 1980, and a fall distance of $15 \mathrm{~km}$. The vertical shaded bar represents the distance of the Hanford site. Horizontal shaded bar is the fall velocity at which objects falling from $15 \mathrm{~km}$ elevation would land at Hanford. Labels on dots give the average diameter (millimeters [mm]) of a round aggregate having a density of 600 kilograms per cubic meter $\left(\mathrm{kg} / \mathrm{m}^{3}\right)$ and the given fall velocity, as calculated by Wilson and Huang (1979). B, Fall velocity at pressure=1 atmosphere (atm), Temperature=298.15 Kelvin (K), versus diameter, for round falling objects. Red lines represent aggregates (densities less than or equal to $800 \mathrm{~kg} / \mathrm{m}^{3}$ ). Black lines represent particles (densities greater than or equal to $1,000 \mathrm{~kg} / \mathrm{m}^{3}$ ). Objects falling at faster than about $1.2 \mathrm{~m} / \mathrm{s}$ from $15 \mathrm{~km}$ under these wind conditions would land upwind from Hanford. All particles having densities greater than or equal to $1,000 \mathrm{~kg} / \mathrm{m}^{3}$ and diameters greater than $0.25 \mathrm{~mm}$ would fall faster than about $1.2 \mathrm{~m} / \mathrm{s}$ and would therefore land upwind of Hanford. 
- Density of individual particles $\left(\rho_{p, i}\right)$. The density of individual particle classes (table 5) is calculated according to its componentry as explained in the mean aggregate size section of this report.

- Deposit density $\left(\rho_{d}\right)$. Ash3d calculates mass per unit area $(M)$ and converts $(M)$ to deposit thickness $(T)$ assuming a density $\left(\rho_{\mathrm{d}}\right)$ of $1,000 \mathrm{~kg} / \mathrm{m}^{3}$. This value of $\left(\rho_{d}\right)$ is intermediate between new-fallen densities, which ranged from less than 100 to more than $1,000 \mathrm{~kg} / \mathrm{m}^{3}$ at Mount St. Helens in 1980 (SarnaWojcicki and others, 1981), and higher densities that follow rain or compaction. Densities of 400-2,000; $1,150-1,350 ; 200-800$; and $1,200-1,300 \mathrm{~kg} / \mathrm{m}^{3}$ have been measured at Pinatubo (Paladio-Melosantos and others, 1996); Eyjafjallajökull (Bonadonna and others, 2011); Redoubt Volcano (Scott and McGimsey, 1994); and Chaitén (Alfano and others, 2011) respectively. Using a value of $\rho_{\mathrm{d}}=1,000 \mathrm{~kg} / \mathrm{m}^{3}$ also conveniently implies that $T=1 \mathrm{~mm}$ when $M=1 \mathrm{~kg} / \mathrm{m}^{2}$. Changing the deposit density from $1,000 \mathrm{~kg} / \mathrm{m}^{3}$ would change $T$, but not $M$. The relationship is linear; in other words, using a value of $500 \mathrm{~kg} / \mathrm{m}^{3}$ would double the value of $T$; using $2,000 \mathrm{~kg} / \mathrm{m}^{3}$ would reduce $T$ by half.

- Magma density $\left(\rho_{m}\right)$. Ash3d converts the input value of erupted volume, $\mathrm{km}^{3} \mathrm{DRE}$, into mass, in $\mathrm{kg}$, assuming a magma density of $2,500 \mathrm{~kg} / \mathrm{m}^{3}$. Like deposit density, the magma density is hard-coded into Ash3d and is a round number that lies within the range of observed densities. Magma contains melt, whose density ranges from about 2,200 to $2,600 \mathrm{~kg} / \mathrm{m}^{3}$ depending on composition, temperature and dissolved volatile content (Lange, 1994; Ghiorso and Sack, 1995). It also contains crystals whose densities range from about 2,500 to $3,200 \mathrm{~kg} / \mathrm{m}^{3}$ depending on crystal type, composition, and temperature (Berman, 1988). The percentage of crystals in magma ranges from 0 percent to greater than 60 percent, and in MSH magmas from above 30 to 50 percent by volume (Gardner and others, 1995). Erupted masses calculated using our assumed magma density of $2,500 \mathrm{~kg} / \mathrm{m}^{3}$ are about 8 percent greater than those using $2,300 \mathrm{~kg} / \mathrm{m}^{3}$ as reported by Carey and others (1995) for MSH magmas, but this difference is well within the uncertainty in deposit volumes.

- Diffusion Coefficient $\left(K_{x}\right)$. Mastin and others (2016) systematically varied $K_{x}$ from 0 to 3,000 square meters per second $\left(\mathrm{m}^{2} / \mathrm{s}\right)$ in MSH test simulations and found that non-zero values of $K_{x}$ did not measurably improve the agreement compared to $K_{x}=0$. However, setting $K_{x}>0$ increased runtime by a factor of three. Thus, we set $K_{x}=0$ for these simulations.

- Aggregate size bins. We use five aggregate size bins with the mass fractions of each bin assigned as shown in table 6 and as described in the mean aggregate size section of this report.

\section{Meteorological Inputs}

The wind and other meteorological conditions are varied in each simulation by randomly picking a start time between January 1, 1980, and January 1, 2010. For meteorology we use data from the ERA Interim model (Dee and others, 2011), published by the ECMWF. It has a roughly $79 \mathrm{~km}$ horizontal spacing between model nodes, 3 -hour time intervals, and 60 pressure levels in the atmosphere extending to 0.1 hectopascal (greater than about $60 \mathrm{~km}$ ). The data extend back to January 1, 1979.

The Interim-ERA data had to be reformatted to be read by Ash3d, which took about a month of processing time. A small percentage of the 65,700 files did not reformat successfully, resulting in failure of 2.1 percent of the simulations.

\section{Model settings}

We chose a horizontal nodal spacing of 0.1 degree (table 4), $8 \times 11 \mathrm{~km}$ at this latitude, which tested well in earlier work (Mastin and others, 2016). Meteorological features smaller than a few times the $79 \mathrm{~km}$ nodal spacing of the ERA Interim model were not captured.

We chose a small model domain to maximize efficiency of calculations under the assumption that ash would be transported primarily to the east, toward Hanford from Mount St. Helens. The small domain may miss instances, however, in which ash takes a roundabout route outside the domain before arriving at Hanford. To evaluate this effect, we also ran 1,000 simulations using a larger model domain $\left(125-111^{\circ} \mathrm{W}\right.$, $\left.43-51^{\circ} \mathrm{N}\right)$. A small number of runs produced slightly higher values of $T$ or airborne ash concentration $(C)$, increasing $T_{10 k}$ by 6 percent and $C_{\text {max }, 10 k}$ by 3.5 percent. This inaccuracy is small relative to other uncertainties.

During test runs we found a surprising relation between model resolution and $T$ or $C$. For a thousand test runs, increasing horizontal resolution from 0.2 to 0.1 to 0.05 degrees, increases $T$ on average by about 10-20 percent and $C$ by about 20-40 percent, although results differ widely from run to run. With increasing resolution, the solution does not converge on a single, more accurate result as Eulerian model tests normally predict (LeVeque, 2002; Schwaiger and others, 2012). We think this relation results from the fact that ash is released in a single column of source nodes (fig. $4 B$ ) having a footprint (nodal area on the ground surface) determined by the nodal spacing. In higher-resolution runs, the same mass of ash occupies a smaller footprint, hence its airborne concentration is greater and, as it falls out, the deposit is thicker. This greater concentration is advected downwind. At nodal spacings smaller than the source region, model accuracy does not improve because the model is unable to capture the physics of the rising and spreading ash column. An optimal spacing would be roughly equal to the horizontal dimension of the volcanic plume at the neutral buoyancy elevation. This dimension increases with eruption size, from tens to hundreds of kilometers, for the range of eruption sizes considered here. We conclude that choosing a constant nodal spacing may introduce an uncertainty of tens of percent in the result. 
Model testing found that varying vertical cell spacing $(d z)$ between 0.5 and $2 \mathrm{~km}$ has less than 10 percent effect on deposit thickness but as much as 30 percent on airborne concentration. The insensitivity in $T$ seems to imply that most tephra is falling vertically. Halving vertical spacing quadruples run time; hence we chose $d z=2 \mathrm{~km}$ for speed. Ash3d interpolates linearly between the nearest nodes in the ERA Interim model (in which spacing is tens of meters at ground level) to obtain pressure, temperature, and wind vectors at each height.

Ash3d does not calculate wet deposition, which would require difficult assumptions of the size and density of falling ashy raindrops. Ash3d can incorporate topography, but the
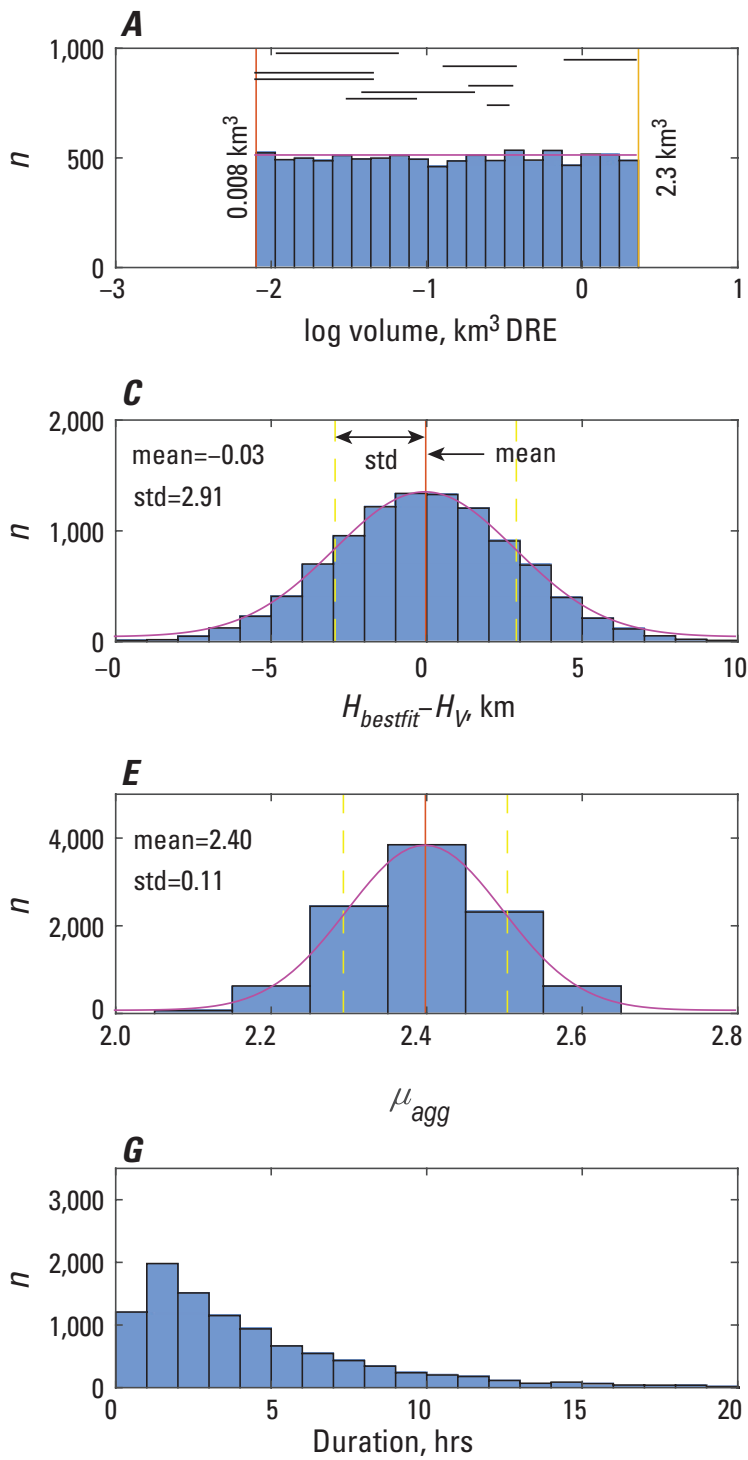

implementation uses a crude cut-cell method, which creates a brickwork pattern of topography, sometimes creating deposit artifacts on the upwind sides of mountain ranges. Topography around Hanford is fairly subdued, and test runs with and without topography produced nearly identical values of $T$ and $C$. Thus, we did not include topography.

\section{Modeling Methodology}

We attempted a total of 10,000 simulations using these inputs. Table S1 of the accompanying Data Release (Mastin and others, 2020) lists the inputs for each run. Histograms (fig. 9) illustrate that the input distributions resemble the pdfs specified.
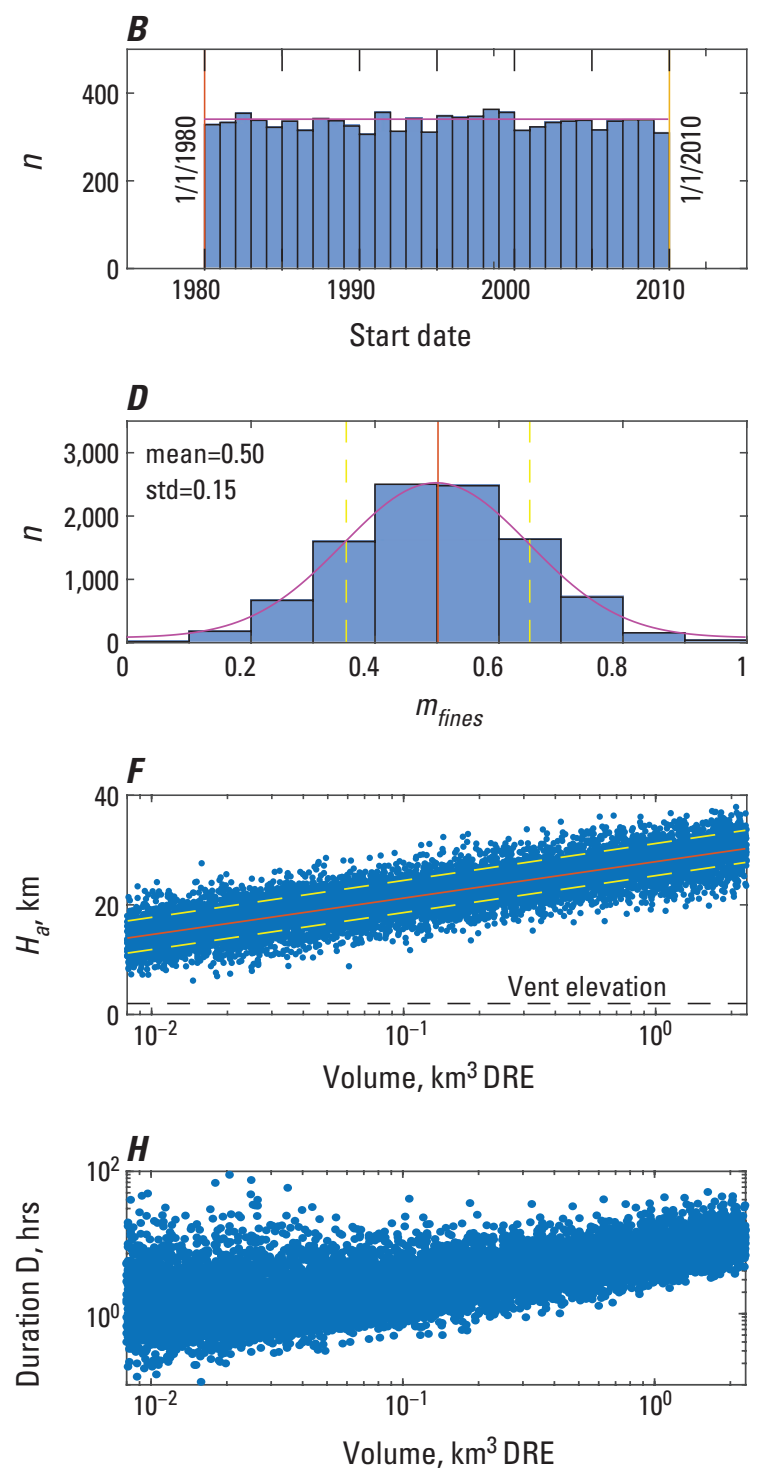

Figure 9. Distribution of inputs used in the simulations. $A$, Histogram of the number of simulations versus the log of erupted volume. Horizontal bars give Nathenson's (2017) range of volumes for eruptions listed in table 2. B, Distribution of eruption start dates. $C$, Distribution of plume height above or below $H_{\text {bestit }}$ calculated from equation 3. D, Distribution of $m_{\text {fines }}$ used in simulations. $E$, Distribution of $\mu_{\text {agg. }}$. F, Plume height versus erupted volume. The red line represents $H_{\text {bestrit }}$ the yellow dashed lines represent $H_{\text {bestrit }} \pm 2.9 \mathrm{~km}$. Points are densest near $H_{\text {bestfit' }}$ as quantified in figure 9C. G, Distribution of eruption durations. $H$, Duration versus log volume. Magenta lines in $A$ through $E$ give theoretical distributions defined in table 3. DRE, dense-rock equivalent; $H_{b e s t f i t}$ plume height above the vent calculated by equation 3; $H_{v^{\prime}}$ plume height above the vent; hr, hour; km, kilometer; $\mathrm{km}{ }^{3}$, cubic kilometer; $m_{\text {fines }}$ mass fraction of a deposit moved into the aggregate size classes; $n$, number of successful runs; std, standard deviation; $\mu_{\text {agg' }}$ median aggregate size. 
Two hundred fifteen simulations ( 2.1 percent) failed because of corrupt wind files, but the remaining runs are enough for the analysis. Table S2 (Mastin and others, 2020) gives tephra thickness, arrival time, fall duration, and grain-size distribution at the Hanford site $\left(46.5507^{\circ} \mathrm{N}\right.$., $119.489^{\circ} \mathrm{W}$.) for each run.

In each simulation, the total $C$ in the ground-level node at Hanford was recorded at each time step (roughly every minute or so) as long as ash was in the air. The maximum value of $C$ in each simulation was taken as $C_{\max }$. The dosage (product of concentration times time) was calculated as $\mathrm{d}_{\mathrm{e}}=\Sigma C_{i} \Delta t_{i}$, where $C_{i}$ is the airborne concentration at each time step and $\Delta t_{i}$ is time-step duration. This dosage was divided by the time over which ash was falling $\left(D_{d}\right)$ to obtain an average concentration $C_{a v g}$. For both the maximum and average airborne concentration, about 56 percent of simulations gave less than $1 \mathrm{mg} /$ $\mathrm{m}^{3}$, and 60 percent gave less than $2 \mathrm{mg} / \mathrm{m}^{3}$. Dosage is used to define aircraft engine tolerance (Clarkson and others, 2016), and may be relevant when considering the amount of ash required to clog air filters.

For each run, documented in Mastin and others (2020), we tabulated inputs (table S1 of Mastin and others (2020)), thickness and fall duration (table S2), maximum airborne concentration, and dosage (table S3). Thickness was ranked in decreasing order (table S4) and each thickness value was assigned a probability $P_{3 \mid 1}$, equal to its rank divided by $(\mathrm{n}+1)$, where $\mathrm{n}$ is the number of successful runs. In the notation of Hoblitt and Scott (2011) $P_{3 \mid 1}=P_{2 \mid 1} \cdot P_{3 \mid 2}$, tables S5 and S6 are analogous to table $\mathrm{S} 4$, but they list maximum and average airborne ash concentration respectively rather than thickness. Plots of $P_{3 \mid 1}$ versus thick-ness and concentration are given in figure 10. About 60 percent of the simulations deposited no tephra at Hanford. Sixty-one percent deposited less than $0.1 \mathrm{~mm}, 88$ percent less than $3.5 \mathrm{~mm}$, and 94 percent $15 \mathrm{~mm}$ or less.

\section{Results}

Following the methodology above, the ranked values of thickness and concentration were interpolated to give $T, C_{\max }$, and $C_{a v g}$ at specified exceedance probabilities (table 8 and fig. 10). For the 10,000-year recurrence interval, $T_{10 K}=51.1$, $C_{\max , 10 K}=3,819$ and $C_{\text {avg }, 10 \mathrm{~K}}=1,513 \mathrm{mg} / \mathrm{m}^{3}$.

The values of $T_{10 K}$ and $C_{\max , 10 K}$ were also calculated as a function of the number of runs completed ( $n$; fig. 11). Changes in $T_{10 k}$ or $C_{\max , 10 k}$ with $n$ result from changes to the statistical distribution as $n$ changes. Ideally, $T_{10 k}$ and $C_{\max , 10 k}$ should converge on a stable value with increasing $n$. After about 5,000 runs, $T_{10 K}$ is within about 5 percent of its final value, whereas more than 6,000 are required to bring $C_{\max , 10 \mathrm{~K}}$ within 5 percent of its final value.
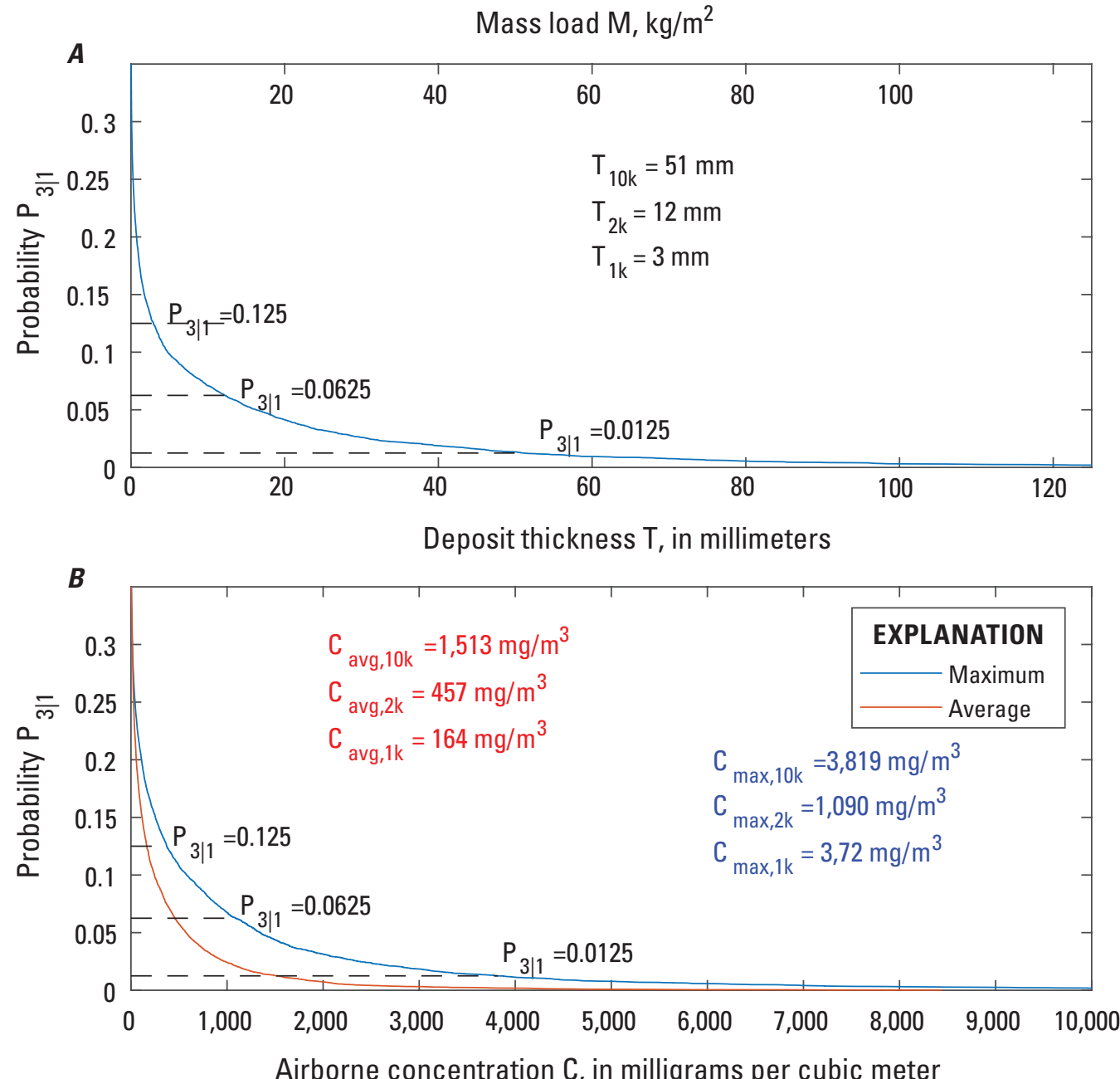

Figure 10. Graphs of probability of exceedance of a given tephra thickness or ash concentration $\left(P_{311}\right)$ versus thickness and concentration. $A$, Plot of exceedance probability $P_{3 \mid 1}$ versus deposit thickness. $B$, Plot of $P_{311}$ versus ground-level maximum $\left(C_{\max }\right)$ and average $\left(C_{\text {avg }}\right)$ airborne ash concentration in milligrams per cubic meter $\left(\mathrm{mg} / \mathrm{m}^{3}\right)$. The exceedance probability is the probability that any eruption will result in tephra-fall thickness $(T)$ or airborne ash concentration (C) exceeding the value given on the $x$ axis. $\mathrm{kg} / \mathrm{m}^{2}$, kilogram per square meter; $\mathrm{mm}$, millimeter. 
Table 8. Threshold values of tephra-fall thickness in millimeters (which is equal to mass load in kilograms per square meter) and airborne concentration at different exceedance probabilities $\left(P_{3 \mid l}\right)$.

[Abbreviations: $C_{\max }$ maximum airborne concentration during the period of tephra fall; $C_{a v e}$, average airborne concentration during the period of tephra fall; mg/ $\mathrm{m}^{3}$, milligram per cubic meter; mm, millimeter; $T$, tephra-fall thickness]

\begin{tabular}{ccccc}
\hline Probability $\boldsymbol{P}_{3 \mid \mathbf{1}}$ & Recurrence years & $\boldsymbol{T}_{\text {, in } \mathbf{~ m m}}$ & $\boldsymbol{C}_{\mathbf{m a x}}$ in $\mathbf{~} \mathbf{g} / \mathbf{m}^{\mathbf{3}}$ & $\boldsymbol{C}_{\text {avg' }}$ in $\mathbf{~ g / / \mathbf { m } ^ { 3 }}$ \\
\hline 0.0125 & 10,000 & 51.1 & 3819 & 1513 \\
0.050 & 2,500 & 16.3 & 1350 & 574 \\
0.0625 & 2,000 & 12.2 & 1090 & 457 \\
0.125 & 1,000 & 2.9 & 372 & 164 \\
\hline
\end{tabular}
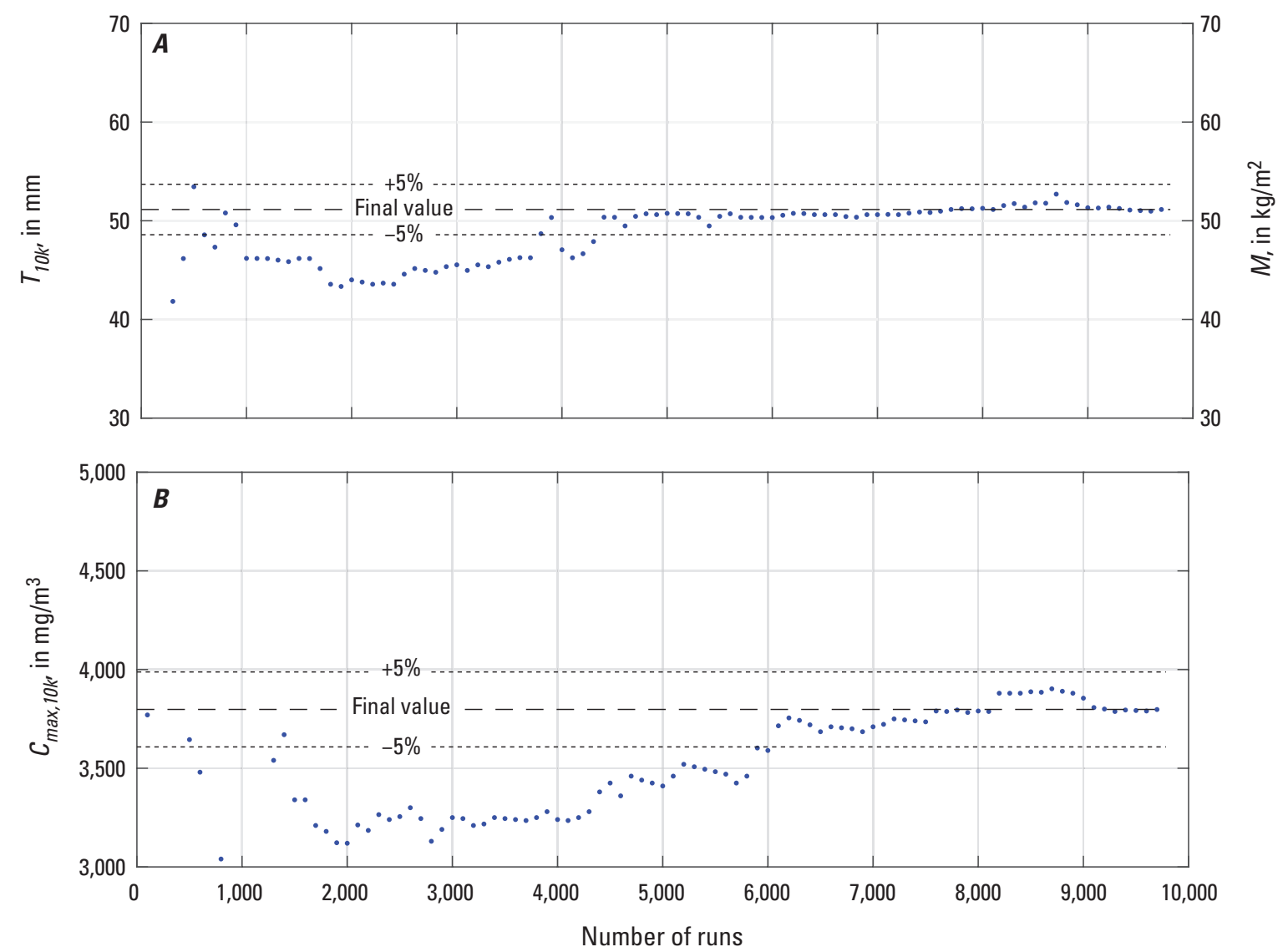

Figure 11. Calculated values of tephra-fall thickness in a "1-in-10,000-year event" $\left(T_{10 k^{\prime}} A\right)$ and maximum airborne ash concentration $\left(C_{\max , 10 \kappa} ; B\right)$ as a function of the number of runs. Horizontal dashed lines give the final value; dotted lines give the final value plus or minus $5 \% . \mathrm{kg} / \mathrm{m}^{2}$, kilogram per square meter; $M$, mass load of tephra deposit; $\mathrm{mm}$, millimeter; $\mathrm{mg} / \mathrm{m}^{3}$, milligram per cubic meter; $P_{3 \mid 1}$ probability of exceedance of a given tephra thickness or ash concentration given that an eruption has occurred; \%, percent.

\section{Deposit Thickness and Mass Load}

Among four simulated deposits where $T \cong T_{10 k}$ (fig. 12), deposition patterns range widely, but in each case the dominant wind was blowing toward Hanford. Among ten runs with $T \cong T_{10 k}$ (table 9), Erupted volumes are in the upper half of the input range $\left(0.62-2.01 \mathrm{~km}^{3}\right)$. Average accumulation rates $\left(T / D_{d}\right)$ ranged widely, from 3.6 to 23.2 millimeters per hour $\left(\mathrm{mm} / \mathrm{hr} ; 1\right.$ to 6 grams per square meter per second $\left.\left[\mathrm{g} / \mathrm{m}^{2} / \mathrm{s}\right]\right)$.
Previous estimates of airborne concentration have assumed that $D_{d}$ are comparable to $D_{e}$, but a plot of these two parameters for all runs (fig. 13) shows surprisingly little correlation. When $D_{d}>0, D_{d}>D_{e}$ about two thirds (66 percent) of the time, with a difference $\left(D_{d}-D_{e}\right)$ of about $2.6 \pm 2.5$ hours (mean \pm standard deviation). Greater fall duration may result when slower, low-elevation winds cause ashfall to linger. Shorter fall duration may result when Hanford lies near the edge of a deposit and catches a brief, passing cloud. 
A. Run 1453

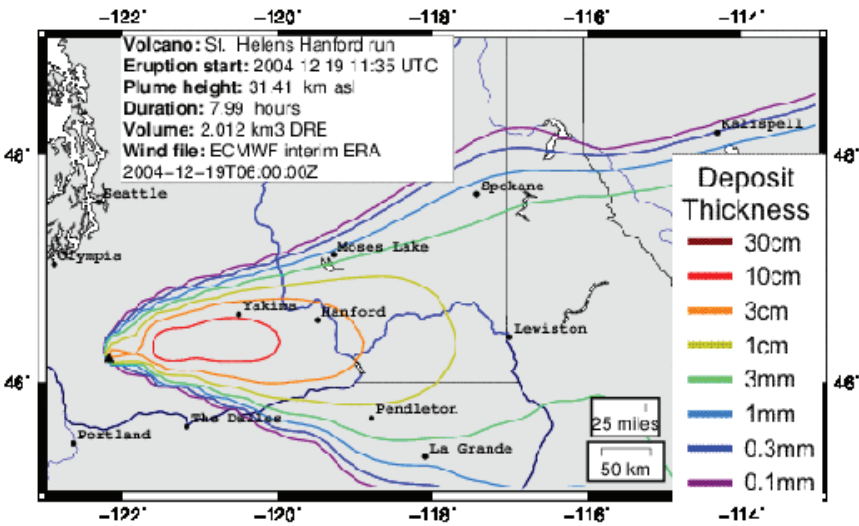

C. Run 0446

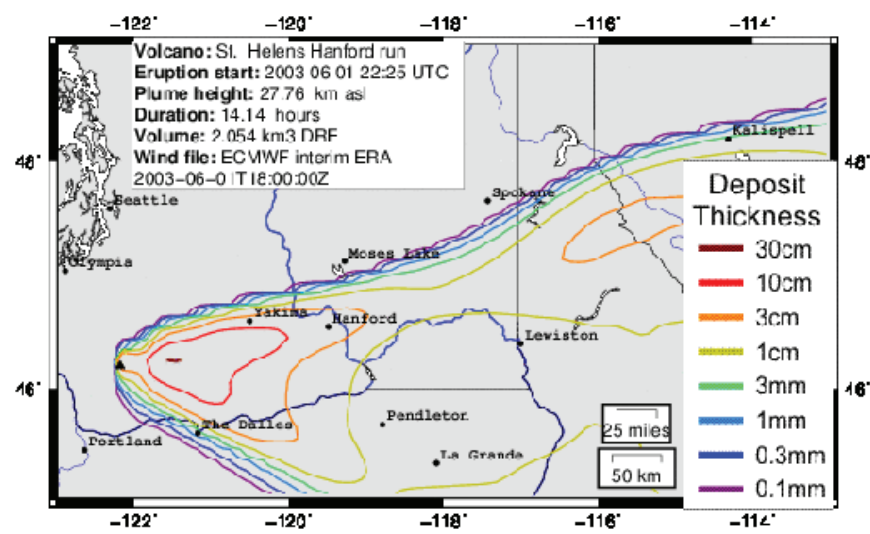

B. Run 4788

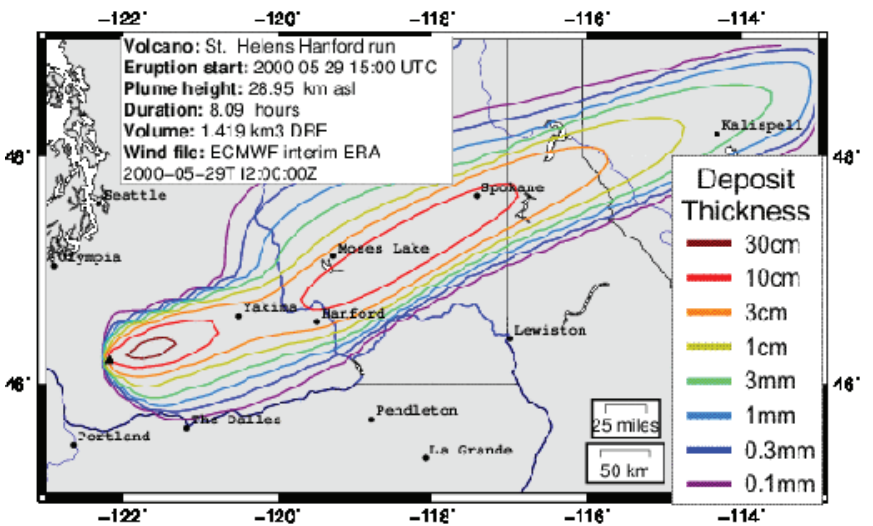

D. Run 0695

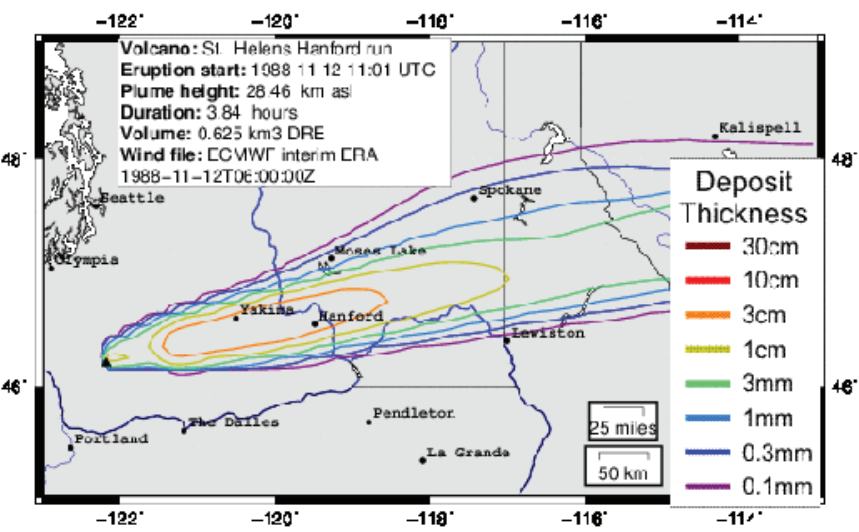

Figure 12. Maps of tephra deposition for four runs whose deposit thickness at Hanford is closest to $T_{10 \mathrm{~K}}$. ASL, above sea level; cm, centimeter; DRE, dense-rock equivalent; ECMWF Interim ERA ,European Centre for Medium-Range Weather Forecasts Interim Reanalysis; km, kilometer; km³, cubic kilometer; mm, millimeter; UTC, coordinated universal time.

Table 9. Table of runs yielding deposit thicknesses close to $T_{10 \mathrm{~K}}$

[Deposit arrival time $\left(t_{d}\right)$ is in hours after the eruption start, when the deposit thickness first exceeded 0.01 millimeters. Fall duration $\left(D_{d}\right)$ is the time period over which the deposit was falling at a rate exceeding 0.01 millimeters per hour. Abbreviations: asl, above sea level; hrs, hours; km, kilometer; km³ , cubic kilometer; $\mathrm{mm}$, millimeter]

\begin{tabular}{|c|c|c|c|c|c|c|c|c|c|}
\hline Rank & $\boldsymbol{P}_{3 / 1}$ & $\begin{array}{c}\text { Run } \\
\text { number }\end{array}$ & $\mathrm{T}$, in mm & $t_{d^{\prime}}$ in hrs & $D_{d^{\prime}}$ in hrs & $V$, in $\mathrm{km}^{3} \mathrm{DRE}$ & $H$, in $\mathrm{km}$ asl & $D_{e^{\prime}}$ in hrs & $\boldsymbol{m}_{\text {fines }}$ \\
\hline 118 & 0.0121 & 2305 & 51.85 & 2.8 & 15.5 & 0.98 & 30.8 & 4.28 & 0.41 \\
\hline 119 & 0.0122 & 5896 & 51.7 & 3.3 & 10.5 & 0.38 & 28.9 & 2.23 & 0.55 \\
\hline 120 & 0.0123 & 4473 & 51.38 & 3.5 & 13.3 & 2.02 & 31.1 & 8.36 & 0.48 \\
\hline 121 & 0.0124 & 1453 & 51.26 & 2.5 & 7.2 & 2.01 & 31.4 & 7.99 & 0.61 \\
\hline 122 & 0.0125 & 4788 & 51.2 & 5.4 & 16.4 & 1.42 & 28.9 & 8.09 & 0.71 \\
\hline 123 & 0.0126 & 446 & 50.97 & 2.2 & 9.3 & 2.05 & 27.8 & 14.14 & 0.56 \\
\hline 124 & 0.0127 & 695 & 50.79 & 1.4 & 6.4 & 0.62 & 28.5 & 3.84 & 0.55 \\
\hline 125 & 0.0128 & 743 & 50.71 & 2.6 & 5.8 & 1.82 & 34.8 & 4.59 & 0.51 \\
\hline 126 & 0.0129 & 6274 & 50.62 & 2.1 & 14.3 & 1.88 & 28 & 12.51 & 0.70 \\
\hline 127 & 0.013 & 6124 & 50.62 & 8.8 & 12.1 & 0.99 & 29.8 & 4.93 & 0.53 \\
\hline
\end{tabular}




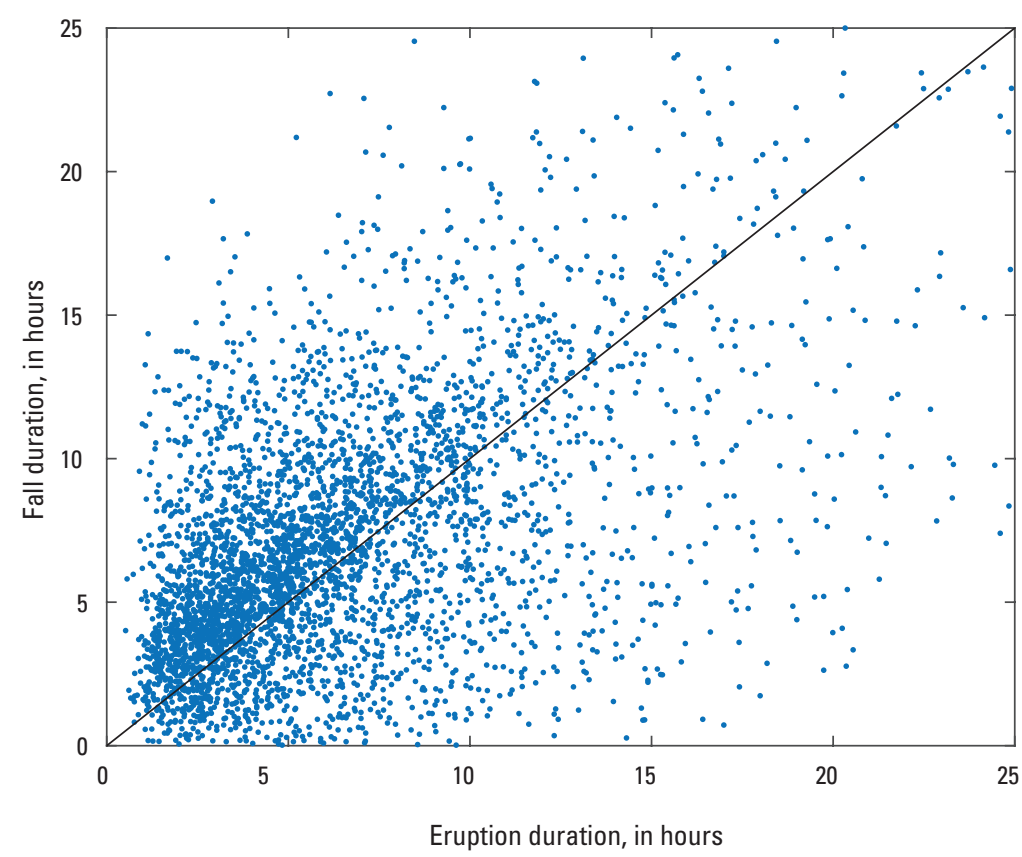

Figure 13. Tephra-fall duration at Hanford, Washington, versus eruption duration, excluding model runs for which fall duration is zero. If fall duration at Hanford were comparable to eruption duration in each simulation, these dots would be concentrated near the diagonal line.

Table 10. Table of runs producing ash concentrations close to $C_{\max , 10 K}$.

[Abbreviations: asl, above sea level; DRE, dense-rock equivalent; hrs, hours; $\mathrm{km}$, kilometer; $\mathrm{km}^{3}$, cubic kilometer; mg $/ \mathrm{m}^{3}$, milligram per cubic meter; mg-s/m³, milligram-seconds per cubic meter; $\mathrm{mm}$, millimeter]

\begin{tabular}{|c|c|c|c|c|c|c|c|c|c|c|}
\hline Rank & $\boldsymbol{P}_{3 / 1}$ & Run Number & $\begin{array}{l}C_{\max } \text { in } \\
\mathrm{mg} / \mathrm{m}^{3}\end{array}$ & $t_{d^{\prime \prime}}$ in hrs & $D_{d^{\prime \prime}}$ in hrs & $\begin{array}{c}\text { Dosage,in } \\
\mathrm{mg}-\mathrm{s} / \mathrm{m}^{3}\end{array}$ & $T$, in $\mathrm{mm}$ & $\begin{array}{c}V_{\text {, in } \mathrm{km}^{3}} \\
\text { DRE }\end{array}$ & $H$, in $\mathrm{km}$ asl & $D_{e^{\prime}}$ in hrs \\
\hline 118 & 0.0121 & 6,775 & 3,900 & 4.2 & 12 & $4.77 \mathrm{E}+07$ & 36.6 & 0.6 & 28.5 & 3.6 \\
\hline 119 & 0.0122 & 7,132 & 3,890 & 14.7 & 7.7 & $3.63 \mathrm{E}+07$ & 21.4 & 1.8 & 29.9 & 8.99 \\
\hline 120 & 0.0123 & 7,943 & 3,880 & 9 & 6.4 & $4.17 \mathrm{E}+07$ & 24 & 0.6 & 25.8 & 5.43 \\
\hline 121 & 0.0124 & 5,355 & 3,880 & 6 & 18.4 & $6.09 \mathrm{E}+07$ & 37.4 & 0.9 & 24.9 & 10.07 \\
\hline 122 & 0.0125 & 3,330 & 3,830 & 5 & 5.6 & $2.56 \mathrm{E}+07$ & 39.8 & 1.6 & 32.2 & 5.66 \\
\hline 123 & 0.0126 & 5,551 & 3,800 & 3.4 & 6.1 & $4.89 \mathrm{E}+07$ & 74.5 & 1.8 & 34 & 5.16 \\
\hline 124 & 0.0127 & 3,046 & 3,790 & 7 & 9.4 & $3.54 \mathrm{E}+07$ & 21.4 & 0.4 & 21.6 & 9.17 \\
\hline 125 & 0.0128 & 8,227 & 3,780 & 6.2 & 13.5 & $5.58 \mathrm{E}+07$ & 39.3 & 0.5 & 30.8 & 2.11 \\
\hline 126 & 0.0129 & 7,921 & 3,780 & 8.1 & 4.5 & $2.27 \mathrm{E}+07$ & 8.6 & 0.9 & 31.4 & 3.57 \\
\hline 127 & 0.0130 & 5,175 & 3,780 & 2.2 & 11 & $6.14 \mathrm{E}+07$ & 96.6 & 1.5 & 32.8 & 5.08 \\
\hline
\end{tabular}

\section{Airborne Concentration}

For runs where $C_{\max } \cong C_{\max , 10 k}$, key inputs are summarized in table 10; similar lists for $C_{\max } \cong C_{\max , 2 k}, C_{\max } \cong C_{\max , l k}$ and $C_{\text {avg }} \cong C_{\max , 10 k}$ are given in tables 11-13. When $C_{\max } \cong C_{\max , 10 k}$, erupted volumes for runs in table 10 are $0.4-1.8 \mathrm{~km}^{3} \mathrm{DRE}$. For the same runs, tephra starts falling at Hanford 2.2-14.7 hours after the eruption starts and falls for 4.5-18.4 hours. Deposits are $9-96 \mathrm{~mm}$ thick, and average accumulation rates are 2.3$19.1 \mathrm{~mm} / \mathrm{hr}$. Concentration versus time (fig. 14A) is mostly
Gaussian in shape with peak values that last only a few hours before dropping to less than 80 percent of the peak value. Dosages (fig. $14 D$, table 10 ) range from $3.5 \times 10^{7}$ to $6.1 \times 10^{7}$ milligram-seconds per cubic meter $\left(\mathrm{mg}-\mathrm{s} / \mathrm{m}^{3}\right)$, reflecting the range of time over which these concentrations persisted.

\section{Grain-Size Distribution}

Tephra fall deposits at Hanford have coarser grain-size distributions in simulations where $T \cong T_{10 k}$ (table 14, fig. 15A) 
Table 11. Table of runs producing ash concentrations close to $C_{\max , 2 k}$

[Abbreviations: asl, above sea level; DRE, dense-rock equivalent; hr, hour; km, kilometer; $\mathrm{km}^{3}$, cubic kilometer; $\mathrm{mg} / \mathrm{m}^{3}, \mathrm{milligram} \mathrm{per} \mathrm{cubic} \mathrm{meter;} \mathrm{mg}$-s $/ \mathrm{m}^{3}$, milligram-seconds per cubic meter; mm, millimeter]

\begin{tabular}{|c|c|c|c|c|c|c|c|c|c|c|}
\hline Rank & $\boldsymbol{P}_{3 / 1}$ & Run Number & $\begin{array}{l}C_{\text {max }^{\prime}} \text { in } \\
\mathrm{mg} / \mathrm{m}^{3}\end{array}$ & $t_{d^{\prime}}$ in hrs & $D_{d^{\prime}}$ in hrs & $\begin{array}{c}\text { Dosage, in } \\
\mathrm{mg}-\mathrm{s} / \mathrm{m}^{3}\end{array}$ & $T$, in $\mathrm{mm}$ & $\begin{array}{c}V, \text { in } \mathrm{km}^{3} \\
\text { DRE }\end{array}$ & $H$, in $\mathrm{km}$ asl & $D_{e^{\prime}}$ in hrs \\
\hline 607 & 0.062 & 6,851 & 1,100 & 7.7 & 7 & $1.10 \mathrm{E}+07$ & 6.8 & 0.4 & 23.6 & 6.14 \\
\hline 609 & 0.0622 & 3,228 & 1,100 & 3.1 & 4.7 & $1.28 \mathrm{E}+07$ & 13.9 & 0.3 & 23.5 & 4.28 \\
\hline 610 & 0.0623 & 7,841 & 1,090 & 8.7 & 5.3 & $8.78 \mathrm{E}+06$ & 5.7 & 0.1 & 22.3 & 1.79 \\
\hline 612 & 0.0625 & 5,594 & 1,090 & 5.4 & 10.4 & $2.02 \mathrm{E}+07$ & 11.5 & 0.3 & 26.4 & 2.86 \\
\hline 613 & 0.0626 & 5,453 & 1,090 & 3.6 & 7 & $5.64 \mathrm{E}+06$ & 3.7 & 0.7 & 27.8 & 4.53 \\
\hline 614 & 0.0627 & 1,670 & 1,090 & 1.7 & 3.7 & $8.16 \mathrm{E}+06$ & 15.2 & 0.2 & 22.6 & 2.92 \\
\hline 615 & 0.0629 & 534 & 1,090 & 1.9 & 6.4 & $1.73 \mathrm{E}+07$ & 34.5 & 0.6 & 25.5 & 5.9 \\
\hline 616 & 0.0630 & 8,916 & 1,080 & 5.3 & 19.8 & $3.42 \mathrm{E}+07$ & 23.1 & 1.2 & 26.8 & 9.62 \\
\hline
\end{tabular}

Table 12. Table of runs producing ash concentrations close to $C_{\max , 1 k^{*}}$

[Abbreviations: asl, above sea level; DRE, dense-rock equivalent; hr, hour; km, kilometer; $\mathrm{km}^{3}$, cubic kilometer; $\mathrm{mg} / \mathrm{m}^{3}$, milligram per cubic meter; mg-s $/ \mathrm{m}^{3}$, milligram-seconds per cubic meter; mm, millimeter]

\begin{tabular}{|c|c|c|c|c|c|c|c|c|c|c|}
\hline Rank & $\boldsymbol{P}_{3 / 1}$ & Run Number & $\begin{array}{l}C_{\max } \text { in } \\
\mathrm{mg} / \mathrm{m}^{3}\end{array}$ & $t_{d^{\prime \prime}}$ in hrs & $D_{d^{\prime}}$ in hrs & $\begin{array}{c}\text { Dosage, in } \\
\mathrm{mg}-\mathrm{s} / \mathrm{m}^{3}\end{array}$ & $T$, in $\mathrm{mm}$ & $\begin{array}{l}V, \text { in } \mathrm{km}^{3} \\
\text { DRE }\end{array}$ & $H$, in $\mathrm{km}$ asl & $D_{e^{\prime}}$ in hrs \\
\hline 1219 & 0.1246 & 9,484 & 374 & 13.5 & 6.5 & $1.99 \mathrm{E}+06$ & 3.7 & 1.27 & 24.6 & 14.99 \\
\hline 1221 & 0.1248 & 73 & 374 & 7.4 & 9.8 & $4.48 \mathrm{E}+06$ & 8.0 & 1.26 & 27.1 & 9.69 \\
\hline 1222 & 0.1249 & 8,777 & 373 & 2.4 & 10.2 & $5.43 \mathrm{E}+06$ & 7.3 & 0.33 & 20.8 & 8.38 \\
\hline 1224 & 0.1251 & 5,875 & 372 & 4.0 & 4.1 & $2.74 \mathrm{E}+06$ & 1.5 & 0.02 & 14.3 & 2.45 \\
\hline 1225 & 0.1252 & 5,098 & 372 & 4.1 & 4.3 & $2.58 \mathrm{E}+06$ & 1.8 & 0.04 & 16.2 & 3.25 \\
\hline 1226 & 0.1253 & 4,692 & 372 & 8.2 & 15.2 & $8.07 \mathrm{E}+06$ & 4.5 & 0.56 & 24.2 & 7.14 \\
\hline 1227 & 0.1254 & 2,510 & 372 & 4.3 & 4.2 & $2.74 \mathrm{E}+06$ & 1.7 & 0.02 & 14.9 & 2.66 \\
\hline 1228 & 0.1255 & 1,149 & 372 & 4.9 & 8.2 & $4.60 \mathrm{E}+06$ & 2.6 & 0.04 & 15.0 & 4.6 \\
\hline
\end{tabular}

Table 13. Run numbers producing ash concentrations at Hanford, Washington, close to $C_{\text {avg, } 10 \mathrm{~K}}$

[Abbreviations: asl, above sea level; DRE, dense-rock equivalent; hr, hour; $\mathrm{km}$, kilometer; $\mathrm{km}^{3}$, cubic kilometer; $\mathrm{mg} / \mathrm{m}^{3}$, milligram per cubic meter; $\mathrm{mg}$-s $/ \mathrm{m}^{3}$, milligram-seconds per cubic meter; mm, millimeter]

\begin{tabular}{|c|c|c|c|c|c|c|c|c|c|c|}
\hline Rank & $\boldsymbol{P}_{3 / 1}$ & Run Number & $\begin{array}{l}C_{\text {avg' }} \text { in } \\
\mathrm{mg} / \mathrm{m}^{3}\end{array}$ & $t_{d^{\prime}}$ in hrs & $D_{d^{\prime}}$ in hrs & $\begin{array}{c}\text { Dosage, in } \\
\mathrm{mg}-\mathrm{s} / \mathrm{m}^{3}\end{array}$ & $T$, in mm & $\begin{array}{c}V, \text { in } \mathrm{km}^{3} \\
\text { DRE }\end{array}$ & $H$, in km asl & $D_{e^{\prime}}$ in hrs \\
\hline 118 & 0.01206 & 5,175 & 1,555 & 2.2 & 11 & $6.14 \mathrm{E}+07$ & 96.6 & 1.5 & 32.8 & 5.08 \\
\hline 120 & 0.01226 & 9,899 & 1,546 & 5.1 & 5.9 & $3.27 \mathrm{E}+07$ & 23.1 & 1.2 & 28.7 & 7.12 \\
\hline 121 & 0.01237 & 5,945 & 1,542 & 5.1 & 11.4 & $6.35 \mathrm{E}+07$ & 43.2 & 1.1 & 25.7 & 10.67 \\
\hline 123 & 0.01257 & 2,129 & 1,510 & 5.2 & 9.1 & $4.95 \mathrm{E}+07$ & 38.2 & 1.1 & 28.9 & 6.57 \\
\hline
\end{tabular}


Table 13. Run numbers producing ash concentrations at Hanford, Washington, close to $C_{\text {avg, } 10 \mathrm{~K}}$ - Continued

\begin{tabular}{|c|c|c|c|c|c|c|c|c|c|c|}
\hline Rank & $P_{3 / 1}$ & Run Number & $\begin{array}{l}C_{\text {avg' }} \text { in } \\
\mathrm{mg} / \mathrm{m}^{3}\end{array}$ & $t_{d^{\prime}}$ in hrs & $D_{d^{\prime \prime}}$ in hrs & $\begin{array}{c}\text { Dosage, in } \\
\mathrm{mg}-\mathrm{s} / \mathrm{m}^{3}\end{array}$ & $T$, in $\mathrm{mm}$ & $\begin{array}{c}V, \text { in } \mathrm{km}^{3} \\
\text { DRE }\end{array}$ & $H$, in km asl & $D_{e^{\prime}}$ in hrs \\
\hline 124 & 0.01267 & 167 & 1,506 & 4.6 & 6.3 & $3.42 \mathrm{E}+07$ & 23.2 & 0.2 & 20.7 & 4.84 \\
\hline 125 & 0.01277 & 9,642 & 1,497 & 1.8 & 8.6 & $4.66 \mathrm{E}+07$ & 94.2 & 1.1 & 28.7 & 6.65 \\
\hline 126 & 0.01288 & 8,701 & 1,494 & 4.7 & 9.8 & $5.28 \mathrm{E}+07$ & 32.1 & 0.5 & 22.8 & 8.57 \\
\hline 127 & 0.01298 & 530 & 1,490 & 9.7 & 8.7 & $4.64 \mathrm{E}+07$ & 22.2 & 1 & 24.1 & 12.41 \\
\hline
\end{tabular}

A

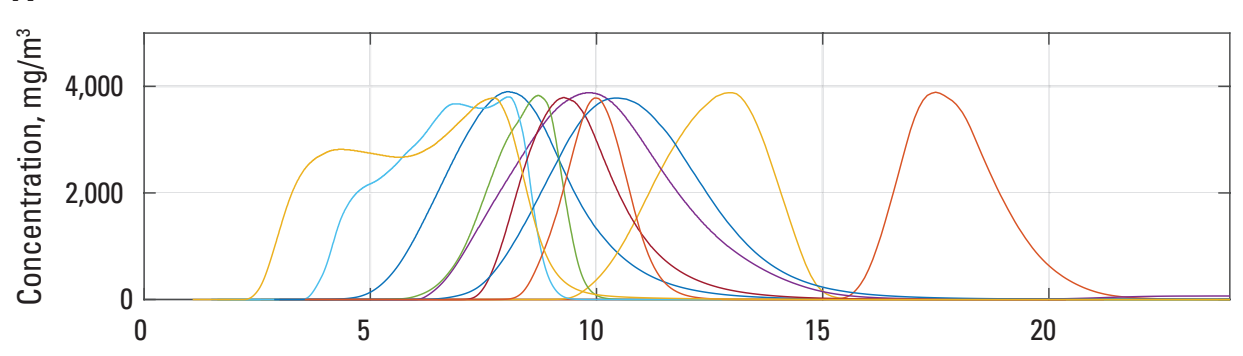

$\boldsymbol{B}$

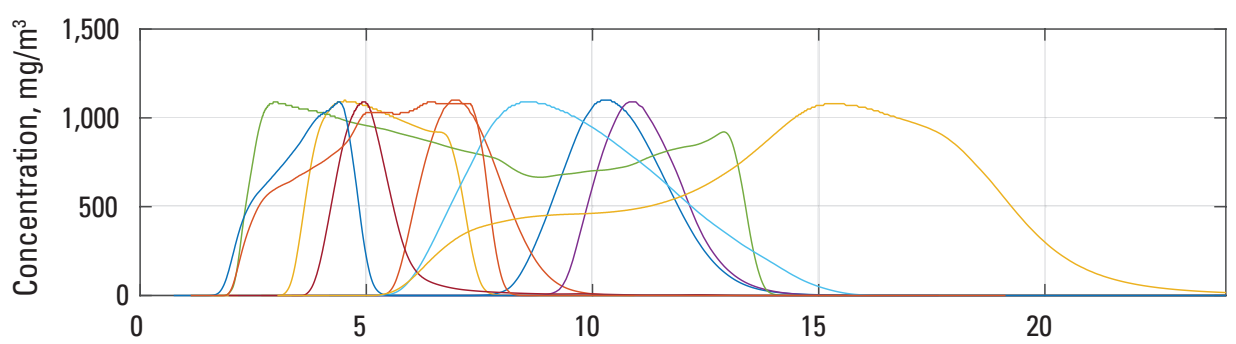

$\boldsymbol{C}$

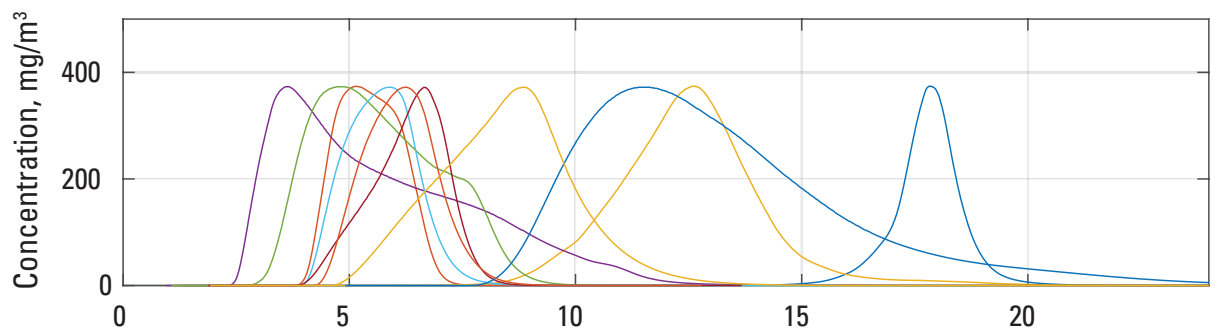

$\boldsymbol{D}$

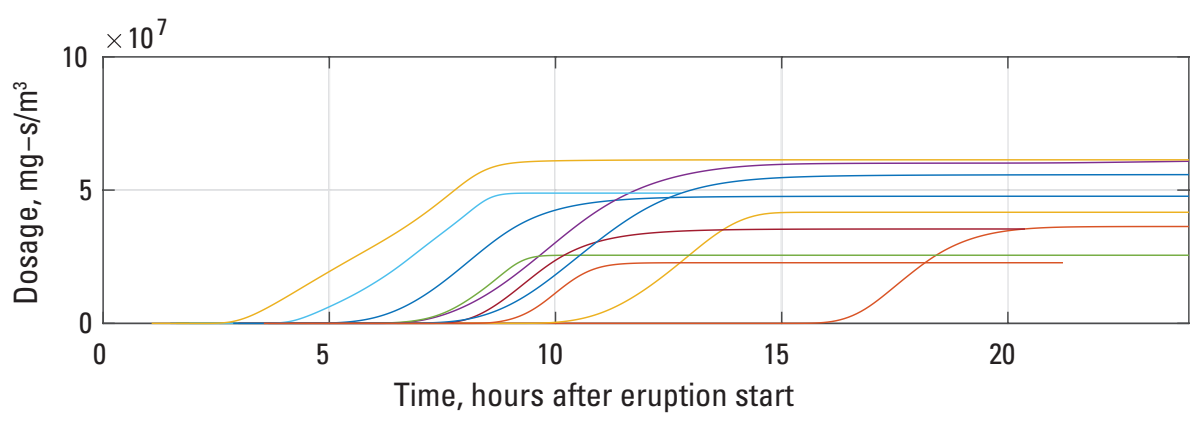

EXPLANATION

Run number

$-6,775$

$-7,132$

7,943

$-5,355$

$-3,330$
$-5,551$

$-3,046$

$-8,227$

7,921

\section{EXPLANATION}

Run number

6,851
$-5,580$

- 3,228

7,841

- 7,368

$-5,594$

$-5,453$

- 1,670

-534
$-8,916$

\section{EXPLANATION \\ Run number \\ 9,484 \\ 8,694 \\ $-73$ \\ $-8,777$ \\ - 7,033 \\ $-5,875$ \\ $-5,098$ \\ 5,692
- \\ $-2,510$ \\ $-1,149$}

\section{EXPLANATION}

Run number

6,775

7,132

- 7,943

- 5,355

$-3,330$

$-5,551$

$-3,046$

- 8,227

- 7,921

$-5,175$

Figure 14. Graphs showing airborne ash concentration versus time for eruption simulations shown in tables $10(A), 11(B)$, and $12(C)$. Airborne ash dosage versus time $(D)$ is also shown for eruptions listed in table 10. Numbers in the legends refer to the run numbers. $\mathrm{mg} / \mathrm{m}^{3}$, milligrams per cubic meter; $\mathrm{mg}-\mathrm{s} / \mathrm{m}^{3}$, milligramseconds per cubic meter. 
than those where $C_{\max } \cong C_{\max , 10 k}$ (table 15) or $C_{\text {avg }} \cong C_{\text {avg, 10k }}$ (table 16), as observed in the $m_{63}$ column of these tables. The $m_{63}$ for the $T \cong T_{10 k}$ runs correlates poorly with $m_{\text {fines }}$ in the input (table 9), and plume heights for runs with a coarse grain-size are also not especially high, suggesting that wind speed plays a strong role in determining grain-size distribution.

Table 14. Grain-size distribution at Hanford, Washington for runs where $T \cong T_{10 k^{\circ}}$

[Rows 3-12 and columns 2-10, give the mass fractions of the particle size indicated in row 2 . Falling aggregates are included in the $\leq 0.063$ millimeter (mm) size class. No size classes larger than $1 \mathrm{~mm}$ were present in these results]

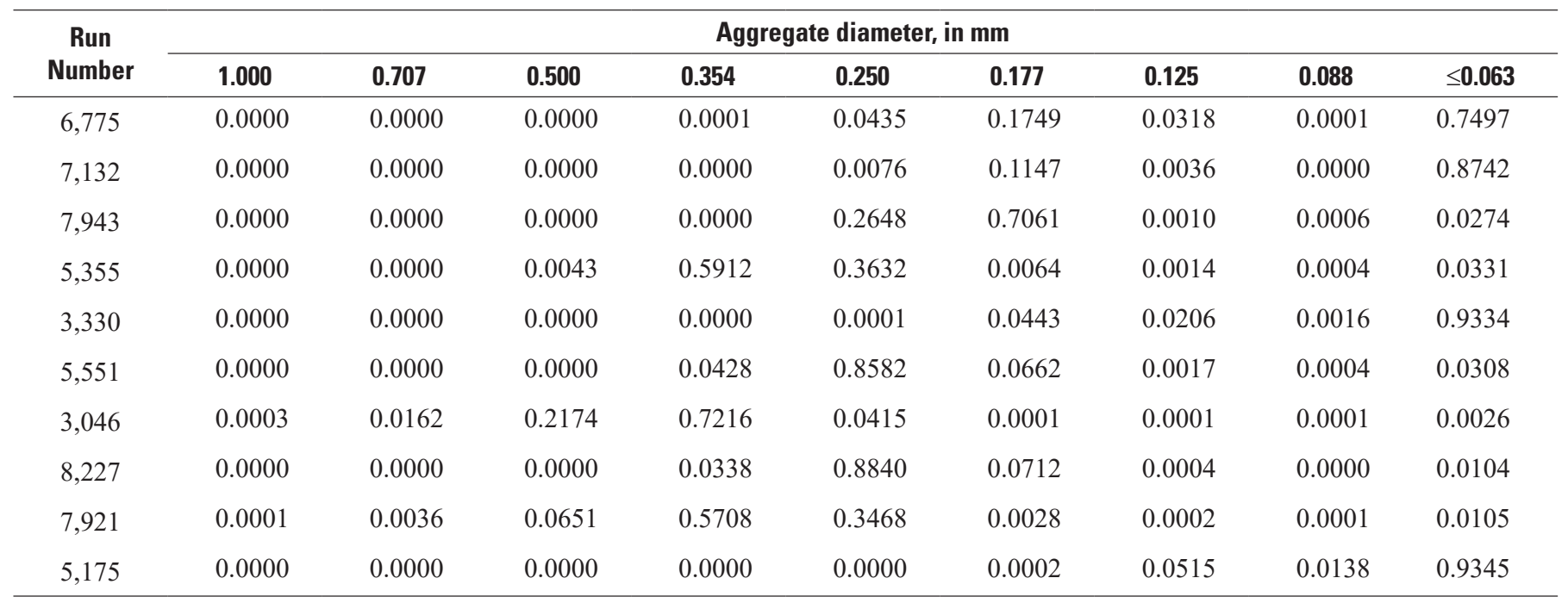

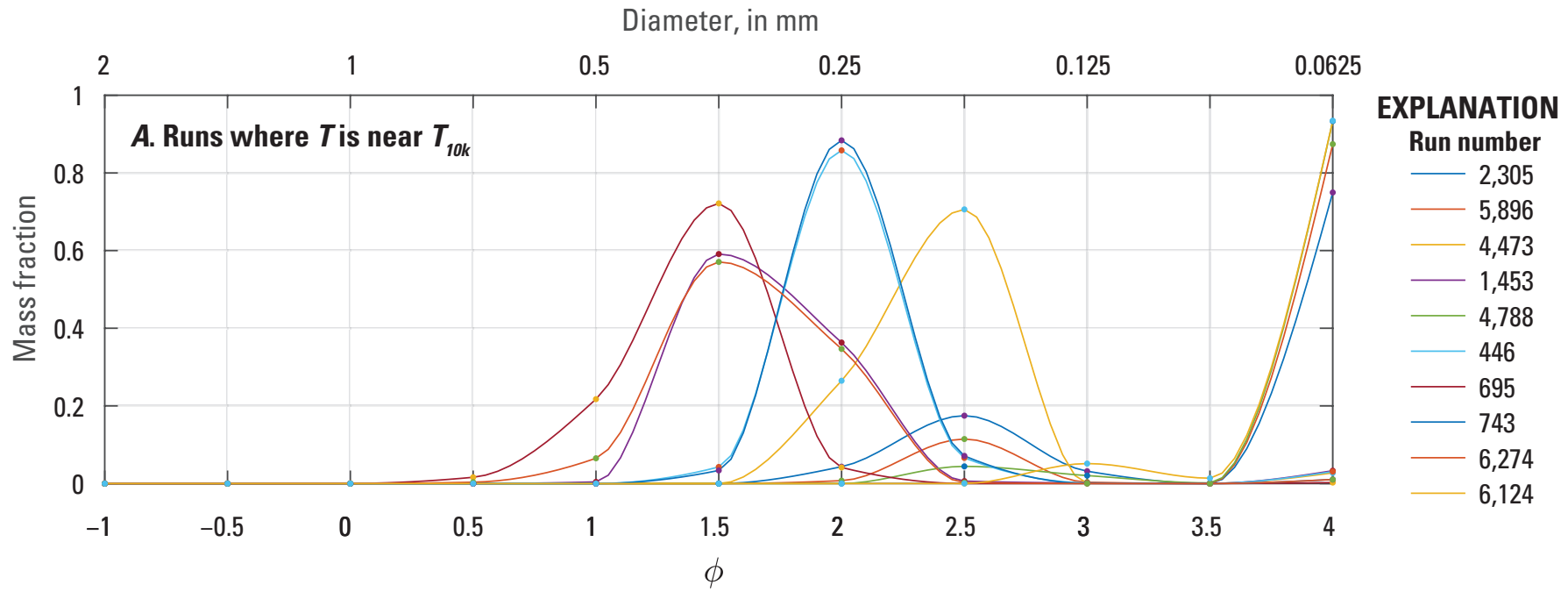

Figure 15 (pages 25-26). Graphs showing grain-size distributions at Hanford, Washington, for several model runs at varying conditions. $A$, Grain-size distributions at Hanford for model runs in table 9 , where tephra fall thickness $(T)$ is close to the 1-in-10,000-year event thickness $\left(T_{10 K}\right) . B$, Grain-size distributions for model run numbers in table 10, where the maximum airborne concentration during the period of tephra fall $\left(C_{\max }\right)$ is close to the value of the maximum airborne ash concentration at Hanford having a recurrence interval of $10,000 \mathrm{yrs}\left(C_{\max , 10 \mathrm{k}}\right)$. C. Grain-size distributions at Hanford for model runs in table 13 , where the average airborne concentration during the period of tephra fall $\left(C_{\text {avg }}\right)$ is close to $C_{\text {avg,10K. Numbers in the }}$ explanation refer to the run numbers. $\mathrm{p}$, particle diameter in millimeters $(\mathrm{mm})$. 

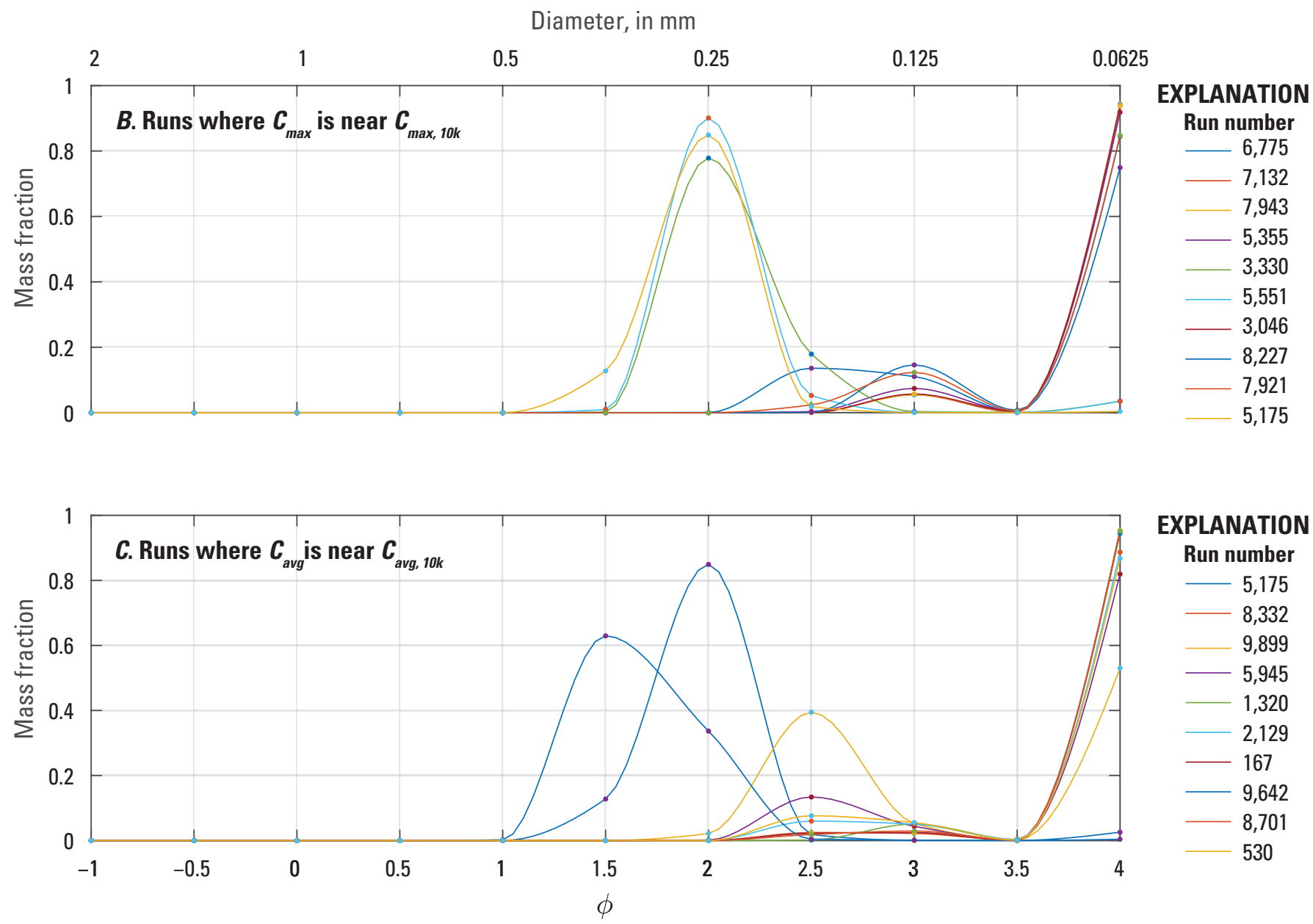

EXPLANATION

Run number

5,175

- 8,332

9,899

- 5,945

- 1,320

- 2,129

- 167

9,642

8,701

530

Figure 15 (pages 25-26).-Continued

Table 15. Grain-size distribution at Hanford for runs producing ash concentrations close to $C_{\max , 10 \mathrm{~K}}$

[Rows 3-12, columns 2-10, give the mass fractions of the particle size indicated in row 2. Falling aggregates are included in the $\leq 0.063$ millimeter (mm) size class. No size classes larger than $1 \mathrm{~mm}$ were present in these results]

\begin{tabular}{clllllllll}
\hline \multirow{2}{*}{$\begin{array}{c}\text { Run } \\
\text { Number }\end{array}$} & \multicolumn{10}{c}{ Aggregate diameter, in $\mathbf{~ m m}$} \\
\cline { 2 - 10 } & $\mathbf{1 . 0 0 0}$ & $\mathbf{0 . 7 0 7}$ & $\mathbf{0 . 5 0 0}$ & $\mathbf{0 . 3 5 4}$ & $\mathbf{0 . 2 5 0}$ & $\mathbf{0 . 1 7 7}$ & $\mathbf{0 . 1 2 5}$ & $\mathbf{0 . 0 8 8}$ & $\leq \mathbf{0 . 0 6 3}$ \\
\hline 6,775 & 0.0000 & 0.0000 & 0.0000 & 0.0000 & 0.0006 & 0.1359 & 0.1107 & 0.0033 & 0.7495 \\
7,132 & 0.0000 & 0.0000 & 0.0000 & 0.0000 & 0.0000 & 0.0009 & 0.0549 & 0.0010 & 0.9432 \\
7,943 & 0.0000 & 0.0000 & 0.0000 & 0.0000 & 0.0000 & 0.0003 & 0.0549 & 0.0056 & 0.9393 \\
5,355 & 0.0000 & 0.0000 & 0.0000 & 0.0000 & 0.0000 & 0.0034 & 0.0742 & 0.0038 & 0.9185 \\
3,330 & 0.0000 & 0.0000 & 0.0000 & 0.0021 & 0.7786 & 0.1793 & 0.0036 & 0.0011 & 0.0353 \\
5,551 & 0.0000 & 0.0000 & 0.0000 & 0.0099 & 0.9011 & 0.0527 & 0.0010 & 0.0000 & 0.0353 \\
3,046 & 0.0000 & 0.0000 & 0.0000 & 0.0000 & 0.0000 & 0.0004 & 0.0574 & 0.0046 & 0.9376 \\
8,227 & 0.0000 & 0.0000 & 0.0000 & 0.0000 & 0.0000 & 0.0010 & 0.1462 & 0.0075 & 0.8453 \\
7,921 & 0.0000 & 0.0000 & 0.0000 & 0.0000 & 0.0000 & 0.0238 & 0.1233 & 0.0051 & 0.8478 \\
5,175 & 0.0000 & 0.0000 & 0.0000 & 0.1277 & 0.8491 & 0.0185 & 0.0005 & 0.0002 & 0.0040 \\
\hline
\end{tabular}


Table 16. Grain-size distribution at Hanford for runs producing ash concentrations close to $C_{\text {avg, } 10 \mathrm{~K}}$.

[Rows 3-12, columns 2-10, give the mass fractions of the particle size indicated in row 2. Falling aggregates are included in the $\leq 0.063$ millimeter (mm) size class. No size classes larger than $1 \mathrm{~mm}$ were present in these results]

\begin{tabular}{clllllllll}
\hline $\begin{array}{c}\text { Run } \\
\text { Number }\end{array}$ & $\mathbf{1 . 0 0 0}$ & $\mathbf{0 . 7 0 7}$ & $\mathbf{0 . 5 0 0}$ & $\mathbf{0 . 3 5 4}$ & $\mathbf{0 . 2 5 0}$ & $\mathbf{0 . 1 7 7}$ & $\mathbf{0 . 1 2 5}$ & $\mathbf{0 . 0 8 8}$ & $\leq \mathbf{0 . 0 6 3}$ \\
\cline { 2 - 8 } 5,175 & 0.0000 & 0.0000 & 0.0000 & 0.1277 & 0.8491 & 0.0185 & 0.0005 & 0.0002 & 0.0040 \\
8,332 & 0.0000 & 0.0000 & 0.0000 & 0.0000 & 0.0000 & 0.0246 & 0.0218 & 0.0007 & 0.9529 \\
9,899 & 0.0000 & 0.0000 & 0.0000 & 0.0000 & 0.0217 & 0.3946 & 0.0523 & 0.0014 & 0.5300 \\
5,945 & 0.0000 & 0.0000 & 0.0000 & 0.0000 & 0.0016 & 0.1338 & 0.0438 & 0.0014 & 0.8194 \\
1,320 & 0.0000 & 0.0000 & 0.0000 & 0.0000 & 0.0000 & 0.0017 & 0.0508 & 0.0031 & 0.9444 \\
2,129 & 0.0000 & 0.0000 & 0.0000 & 0.0000 & 0.0001 & 0.0597 & 0.0504 & 0.0032 & 0.8867 \\
167 & 0.0000 & 0.0000 & 0.0000 & 0.0000 & 0.0000 & 0.0222 & 0.0246 & 0.0001 & 0.9531 \\
9,642 & 0.0000 & 0.0000 & 0.0022 & 0.6295 & 0.3366 & 0.0046 & 0.0013 & 0.0002 \\
8,701 & 0.0000 & 0.0000 & 0.0000 & 0.0000 & 0.0001 & 0.0184 & 0.0293 & 0.0008 & 0.9515 \\
530 & 0.0000 & 0.0000 & 0.0000 & 0.0000 & 0.0001 & 0.0761 & 0.0552 & 0.0015 & 0.8671 \\
\hline
\end{tabular}

\section{Discussion}

In this section we consider these results in the context of their inputs, and the implications of the results for hazards at Hanford.

\section{Results in the Context of Inputs}

Our $T_{10 K}$ value of $51 \mathrm{~mm}$ is about half the $10 \mathrm{~cm}$ estimated by Hoblitt and Scott (2011); but our estimate of $C_{\text {avg, } 10 k}\left(1,513 \mathrm{mg} / \mathrm{m}^{3}\right)$ is nearly identical to the estimate of Snow and Nelson (2012) $\left(1,500 \mathrm{mg} / \mathrm{m}^{3}\right)$. These results bear some scrutiny in the context of our inputs.

In choosing inputs, we used best estimates with no intent to add conservatism. Minimum and maximum erupted volumes ( $V_{\min }$ and $V_{\max }$, respectively) for example, were chosen on the basis of Nathenson's (2017) estimated range for Holocene MSH eruptions rather than those of Carey and others (1995), because the former are better documented and reproducible. However, Nathenson's volume estimates are lower by at least a factor of two than those of Carey and others (1995). Our estimate of $T_{10 k}$, half that of Hoblitt and Scott (2011), is consistent with this. Our choice of a logarithmic probability distribution for $V$ was based on the abundance of small eruptions rather than large ones in the geologic record. The paucity of observations precludes a more specific sizefrequency relationship, but a different one could alter the frequency of the largest eruptions, which strongly control $T_{10 k}$ and $C_{10 k}$.

Our choices of plume height and duration are also important. $H$ and $D_{e}$ are derived by correlation from $V$, with uncertainties indicated by the scatter of data in figure 6 . Eruption rate is proportional to roughly the fourth power of plume height in kilometers above the vent (equation 2); thus, overestimating plume height by 20 percent would double the eruption rate and reduce eruption duration by half, essentially doubling the average airborne concentrations during the fall period. We consider it unlikely however that durations were systematically over- or underestimated by a factor of two; eruption durations in table 9, for example (2-14 hrs for volumes of $0.6-2.0 \mathrm{~km}^{3}$ ), do not appear out of line with observed durations for similar-sized eruptions (see table 1, Mastin and others (2009)).

Other parameters such as $k, F$, and $\rho_{p}$ have uncertainties whose possible effects are listed in table 17. Most of these effects have never been explored.

Our results may be conservative in one respect. Eruptions larger than about $1 \mathrm{~km}^{3}$ DRE produce umbrella clouds that drive ash radially outward, a process not included in this version of Ash3d. Umbrella spreading produces clouds that are circular (fig. 16B) in contrast to the fan shape of clouds of smaller eruptions (fig. 16A). Umbrella clouds spread ash over a wider area, reducing the maximum deposit thickness immediately downwind (Mastin and others, 2014), and making the statistical worst-case (thickest) scenario not so bad. In 1991, Pinatubo produced the biggest umbrella cloud in recent decades (fig. 16B), and erupted about three times more magma (6-10 km³ DRE (Koyaguchi, 1996)) than the largest of our simulations $\left(2.3 \mathrm{~km}^{3} \mathrm{DRE}\right)$.

The dispersal of ash can be quantified by contouring the thickness distribution of an ash deposit as shown in figure $1 G$ for the 1980 deposit, and then constructing plots of $\log$ thickness versus $\operatorname{sqrt}(A)$ as in figure $3 B$. Data can be fit with a best-fit line of slope $k_{0}$ (fig. $3 B$ ), although well-mapped deposits like MSH 1980 are better fit with two lines, of slopes $k_{1}$ and $k_{2}$ (fig. $3 B$ ). Lower absolute slope values reflect broader dispersal. Fierstein and Nathenson (1992) compiled slopes for 27 published deposits. Plotted as a function of the bulk deposit 
Table 17. Estimated range of uncertainty in secondary physical parameters and their possible effects on results.

[The range of uncertainty in these parameters are estimates. Abbreviations: $\mathrm{cm}$, centimeter; DRE, dense-rock equivalent; $\mathrm{m}^{2} / \mathrm{s}, \mathrm{square} \mathrm{meter}$ per second; $\mathrm{kg} / \mathrm{m}^{3}$, kilogram per cubic meter]

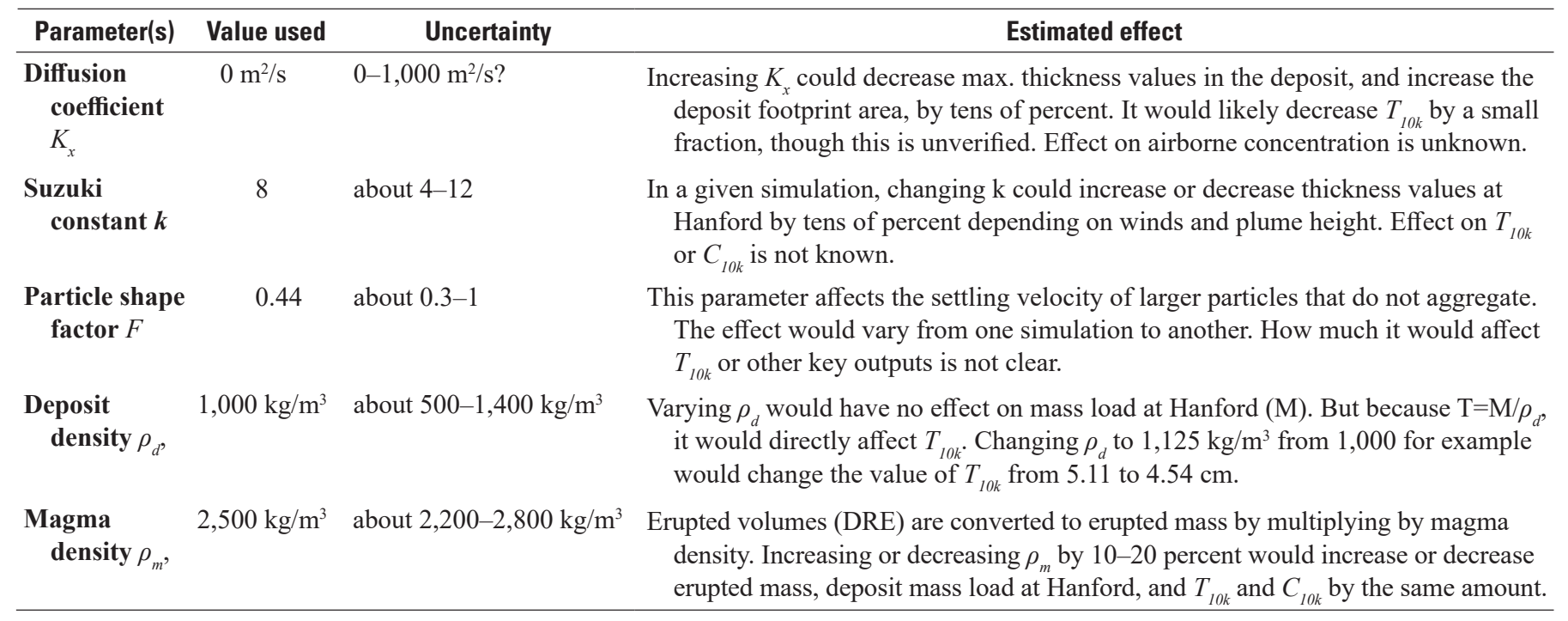

A. Eyjafjallajökull

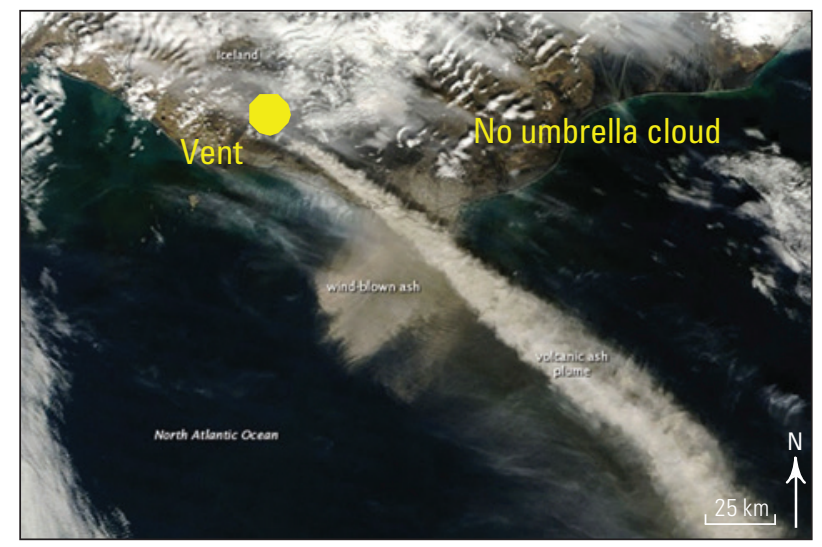

\section{B. Pinatubo}

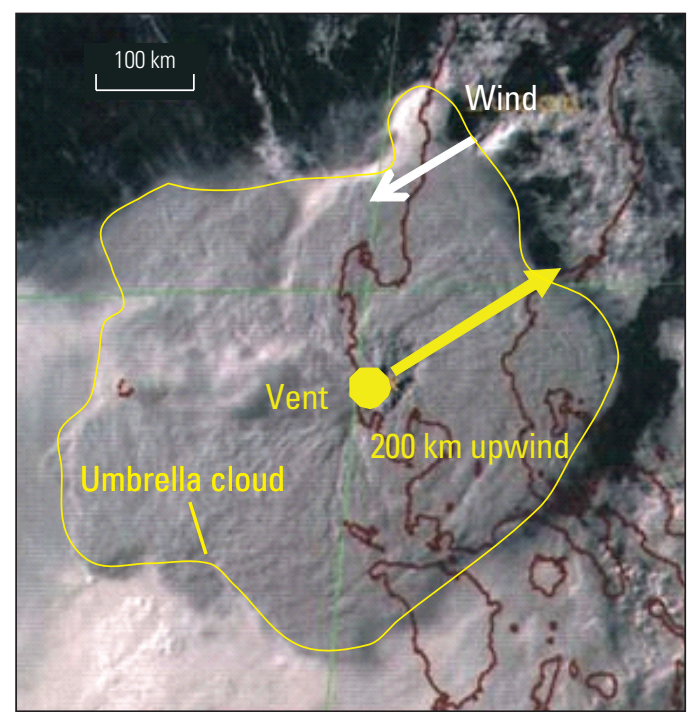

C

Horizontal extent (km)

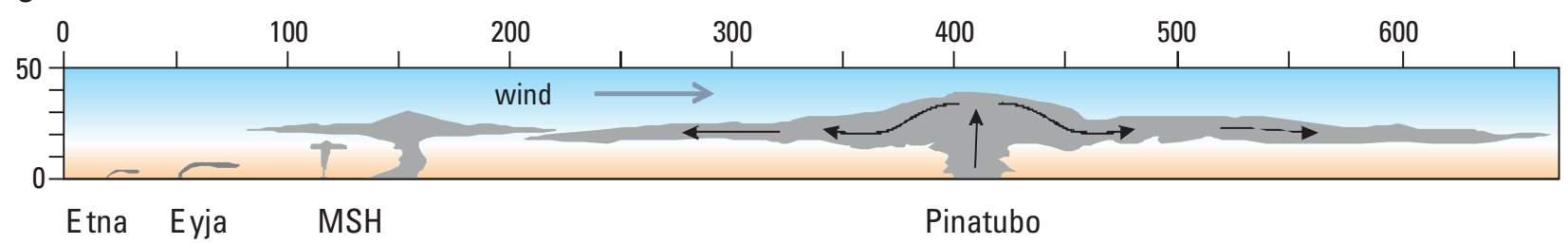

Figure 16. Contrasting ash-cloud shapes from small and large eruptions. $A$, The National Aeronautics and Space Administration Earth Observatory image of the shape of the cloud from the eruption of Eyjafjallajökull (Eyja), Iceland, on May 7, 2010. Under a modest mass eruption rate of $5-10 \times 10^{6}$ kilograms per second $(\mathrm{kg} / \mathrm{s})$, the cloud emanates from a point source, advects downwind in the ambient wind field, and widens into a fan-like shape because of turbulent diffusion. $B$, Japanese geostationary meteorological satellite (GMS) visible image of the shape of cloud from the 1991 Pinatubo eruption, which produced one of the highest mass eruption rates in the past century, $4-20 \times 10^{8} \mathrm{~kg} / \mathrm{s}$ (Koyaguchi, 1996). The massive eruption formed a large, circular umbrella with radial winds that drove ash hundreds of kilometers upwind. $C$, Height and lateral extent in kilometers $(\mathrm{km})$, of some plumes produced by recent eruptions: Etna in 2001 (Scollo and others, 2007), Eyjafjallajökull in 2010 (Arason and others, 2011), Mount St. Helens (MSH) in 1980, both the initial phase (8:30-9:00 a.m. Pacific Daylight Time [PDT]) and later (9:00 a.m.-5:00 p.m. [PDT], and Pinatubo in 1991 (Holasek and others, 1996). 
volume (fig. 17), the absolute values of these slopes generally decrease with increasing erupted volume. The upward-

decreasing trend starts when bulk (not DRE) volumes exceed a few cubic kilometers - near the top of the range of volumes we are modeling. The decreasing trend likely reflects the increasing dominance of umbrella-cloud dispersal for larger eruptions.

\section{Comparison with Measured Airborne Concentrations}

Our estimates of airborne ash concentration for $C_{\text {avg, } 10 \mathrm{k}}$ $\left(1,519 \mathrm{mg} / \mathrm{m}^{3}\right)$ are orders of magnitude higher than any that have been measured. At Soufrière Hills, Montserrat (Searl and others, 2002), Eyjafjallajökull, Iceland (Thorsteinsson and others, 2012), and Mount Spurr, Alaska (Gordian and others, 1996) for example, measured concentrations did not exceed several milligrams per cubic meter (table 18). On May 18, 1980 , measurements in central Washington ranged as much as $33 \mathrm{mg} / \mathrm{m}^{3}$ (Bernstein and others, 1986). However, a review of methods reveals why these values differ from ours.

Measurements like the one that recorded $33 \mathrm{mg} / \mathrm{m}^{3}$ in Yakima in 1980 were taken from a device that resembled a small weather station with a birdhouse roof (fig. 18A). Beneath that roof, air was drawn into a funnel-shaped intake and through a filter (Doug Jager, U.S. Environmental Protection

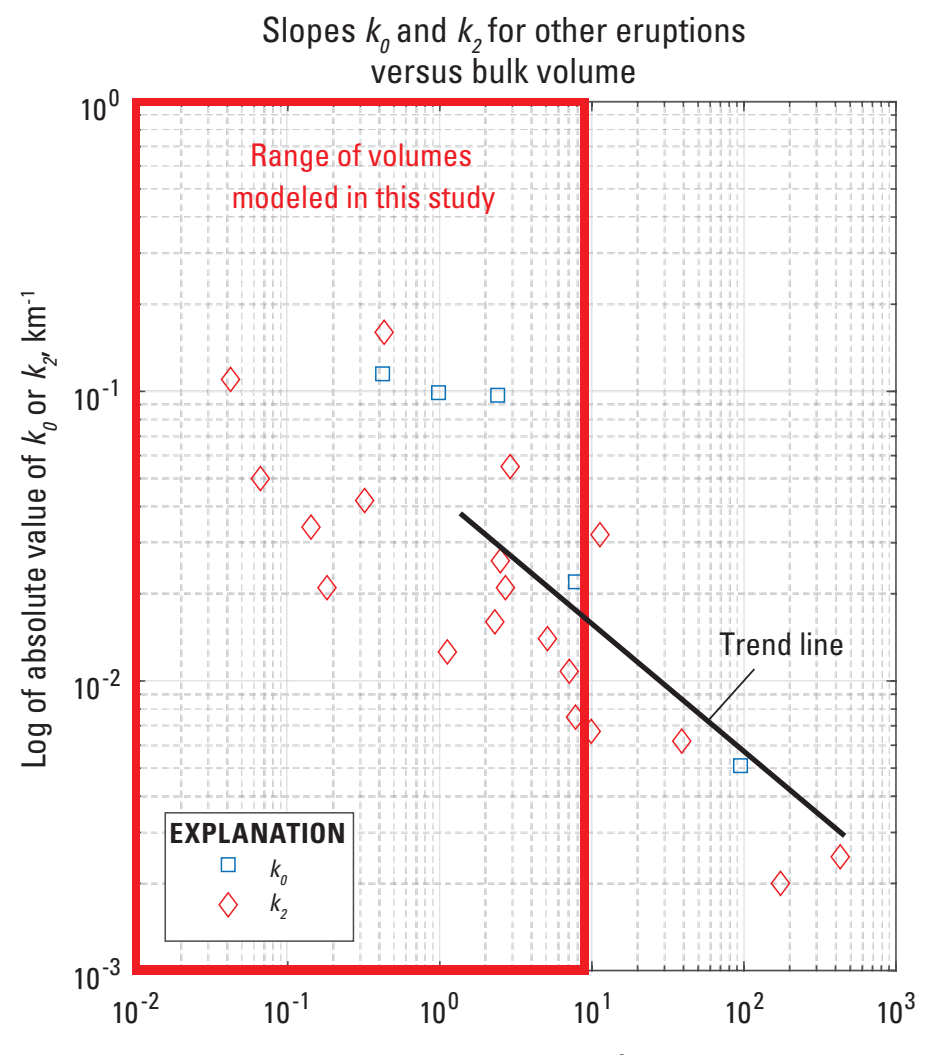

Log bulk volume, $\mathrm{km}^{3}$
Agency, Seattle, written commun., 2017). The filters were weighed every 24 hours, yielding an average value for total suspended particulates. Unpublished worksheets of the Yakima measurement from the Washington State Department of Ecology (unpublished data, 1980) indicate that, on May 18, 1980, the filter was withdrawn before 24 hours. In Colville, Wenatchee, and elsewhere, filters clogged before the end of the 24-hour period and concentrations could not be reported.

Measurements near Yakima provide evidence for how much total ash could have been airborne. Wanapum Dam lies $51 \mathrm{~km}$ northeast of Yakima, directly down the 1980 dispersal axis. As at Yakima, about $10 \mathrm{~mm}\left(8 \mathrm{~kg} / \mathrm{m}^{2}\right)$ of ash fell at Wanapum Dam on May 18, 1980; but at Wanapum, workers laid out trays and recorded mass accumulation rates (Scheidegger and others, 1982), which averaged about $=2.5 \times 10^{-4}$ $\mathrm{kg} / \mathrm{m}^{2} / \mathrm{s}$ for a 9-hour period. Assuming a fall rate of $u=1.5 \mathrm{~m} / \mathrm{s}$ (Durant and others, 2009; Snow and Nelson, 2012), total airborne concentration during the fall period would have been about $=$ about $160 \mathrm{mg} / \mathrm{m}^{3}$ — several times the suspended concentrations measured at Yakima.

During large eruptions, it is not uncommon for downwind areas to receive centimeters of ash in a few hours. For example, the Volcanic Explosivity Index (VEI) 6, 1912 NovaruptaKatmai eruption deposited greater than $30 \mathrm{~cm}$ (consolidated) of ash on Kodiak Island, about $170 \mathrm{~km}$ downwind from the

Figure 17. Graph of slopes of lines on plots of log thickness versus square root of area covered $\left(k_{0}\right.$ and $\left.k_{2}\right)$ compiled from mapped deposits in table 6 of Fierstein and Nathenson (1992), as a function of bulk deposit volume. Red box represents the range of bulk volumes used in this study. One cubic kilometer $\left(\mathrm{km}^{3}\right)$ bulk equals about $0.4 \mathrm{~km}^{3} \mathrm{DRE}$, using the values for magma density $\left(2,500 \mathrm{~kg} / \mathrm{m}^{3}\right)$ and deposit density $\left(1,000 \mathrm{~kg} / \mathrm{m}^{3}\right)$ in our study. $\mathrm{km}^{-1}$, reciprocal kilometer. 
Table 18. Measurements of suspended particle concentrations made during volcanic eruptions.

Abbreviations: $\mathrm{mg} / \mathrm{m}^{3}$, milligram per cubic meter; km, kilometer; PM10, particulate matter smaller than 10 micrometers in diameter; PM2.5, particulate matter smaller than 2.5 micrometers in diameter.

\begin{tabular}{|c|c|c|c|}
\hline Eruption & Concentration & Reference & Comments \\
\hline $\begin{array}{l}\text { Mount St. Helens, } \\
\text { May 18, } 1980\end{array}$ & $\begin{array}{l}\text { As much as } \\
33.4 \mathrm{mg} / \mathrm{m}^{3}\end{array}$ & (Bernstein and others, 1986) & $\begin{array}{l}\text { Measured in Yakima, Washington from filter measurements of } \\
\text { a cyclone-type instrument. Concentration represents total } \\
\text { suspended particles. (Bernstein and others, 1986). Unpublished } \\
\text { measurements included } 17.3 \mathrm{mg} / \mathrm{m}^{3} \text { in Spokane, and } 15.3 \mathrm{mg} / \mathrm{m}^{3} \\
\text { in Coeur d'Alene (Center for Disease Control, 1980). In Colville, } \\
\text { Wenatchee, and elsewhere, filters clogged before the end of the } \\
\text { 24-hour period and concentrations could not be reported. }\end{array}$ \\
\hline $\begin{array}{l}\text { Soufrière Hills, } \\
\text { 1996-2000 }\end{array}$ & $\begin{array}{l}\text { "up to several } \\
\mathrm{mg} / \mathrm{m}^{3} "\end{array}$ & (Searl and others, 2002) & $\begin{array}{l}\text { Respirable dust concentrations measured with cyclone filters and } \\
\text { DustTrak instruments in Plymouth, Cork Hill, Salem, and North, } \\
\text { Montserrat, between September } 1996 \text { and June } 1997 .\end{array}$ \\
\hline
\end{tabular}
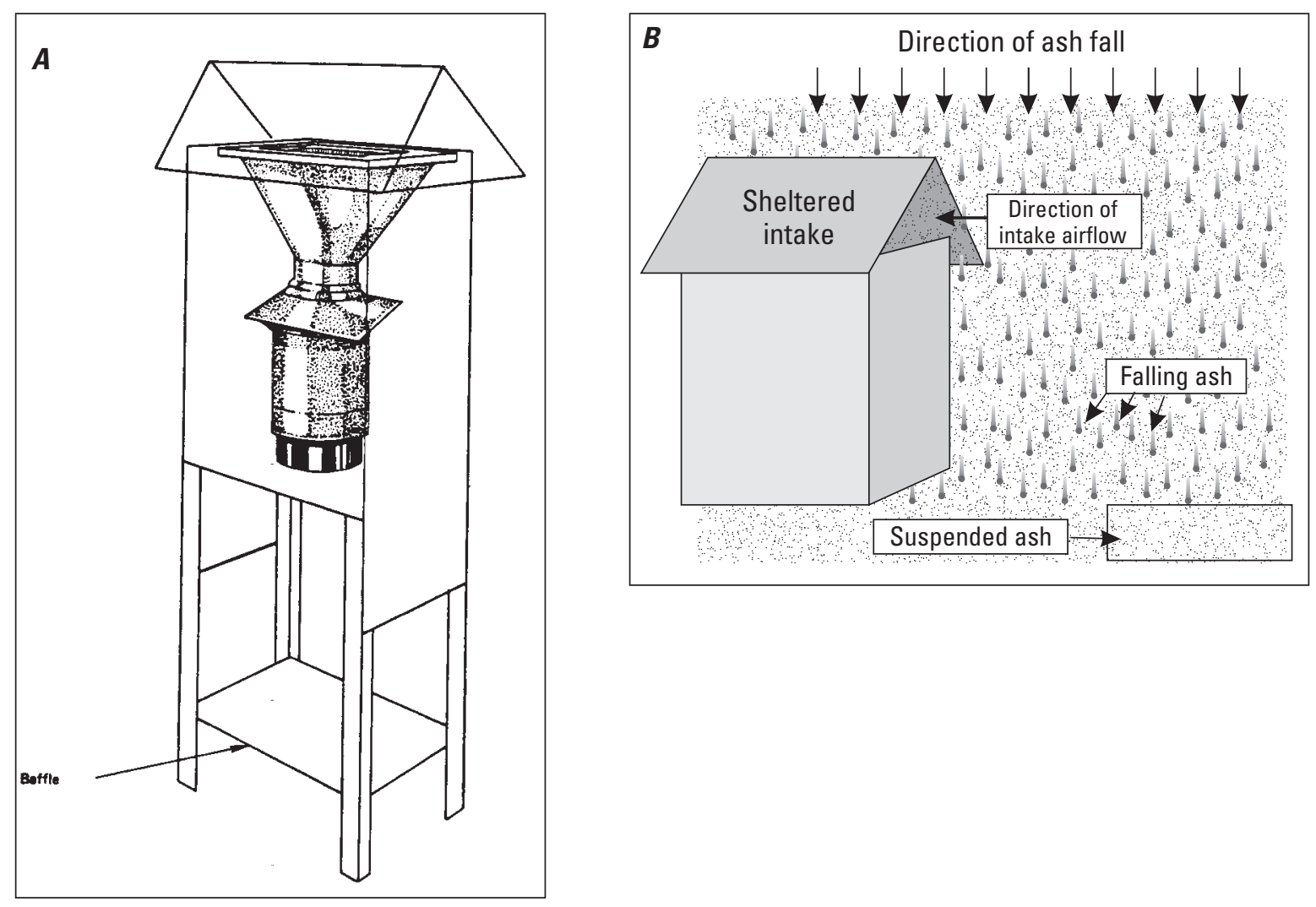

Figure 18. Sketches showing airborne particle sampling tools. $A$, Sketch showing the approximate design of airborne particle samplers of the type used in Yakima, Washington, in May, 1980. Sketch downloaded from appendix B of 40 CFR Part 50, 2017. B, Illustration of falling ash and suspended ash, showing how falling ash may fail to be drawn into the sheltered intake because of its fall velocity. 
volcano (Fierstein and Hildreth, 1992). In 1932, Malargüe, Argentina received about $10 \mathrm{~cm}$ of ash from the 18-hourlong VEI 6 eruption of Cerro Azul (Quizapu), Chile, $106 \mathrm{~km}$ upwind (Hildreth and Drake, 1992). Assuming $u=1.5 \mathrm{~m} / \mathrm{s}$, a fall rate of 1 centimeter per hour $\left(\mathrm{cm} / \mathrm{hr} ; \cong 0.003 \mathrm{~kg} / \mathrm{m}^{2} / \mathrm{s}\right)$ translates to $C \cong 1,800 \mathrm{mg} / \mathrm{m}^{3}$. Average accumulation rates for runs in tables 10 and 13 are in this range.

Estimates using assume a control volume (fig. 19; Snow and Nelson, 2012) in which all mass enters from above, and no mass leaves. We think this method is robust and that $C>$ $1,000 \mathrm{mg} / \mathrm{m}^{3}$ is reasonable given known accumulation rates, but fall velocity adds a level of uncertainty.

\section{The Implications of Uncertain Fall Velocity}

Aggregates used in our study have a settling velocity of about $0.35-0.85 \mathrm{~m} / \mathrm{s}$ (tables 11 and 16 ) and are assumed not to change as they move downwind. But real aggregates may form as the cloud descends and fall faster late in transport (fig. 7). For example, Durant and others' (2009) estimates of $1.5 \mathrm{~m} / \mathrm{s}$ were based on rate of 1980 cloud descent. If the $0.25-0.50-\mathrm{mm}$ diameter aggregates described by Sorem (1982) had a density similar to the deposit density at this location (about $500 \mathrm{~kg} / \mathrm{m}^{3}$ (Sarna-Wojcicki and others, 1981)), their fall velocity would have been 0.85 to $1.9 \mathrm{~m} / \mathrm{s}$ (fig. $8 B$ ). Measurements of $u$ in other studies range from about 0.05 to $4 \mathrm{~m} / \mathrm{s}$ (table 19).

This wide range adds uncertainty to $C$. Both Ash3d and the control-volume method calculate airborne concentration as downward flux through a control volume. Lower fall velocities imply higher airborne concentrations. If aggregate fall velocities are $0.4-4 \mathrm{~m} / \mathrm{s}$ (Taddeucci and others, 2011), rather $0.3-0.8 \mathrm{~m} / \mathrm{s}$, then airborne concentrations could be several times lower than we estimate.

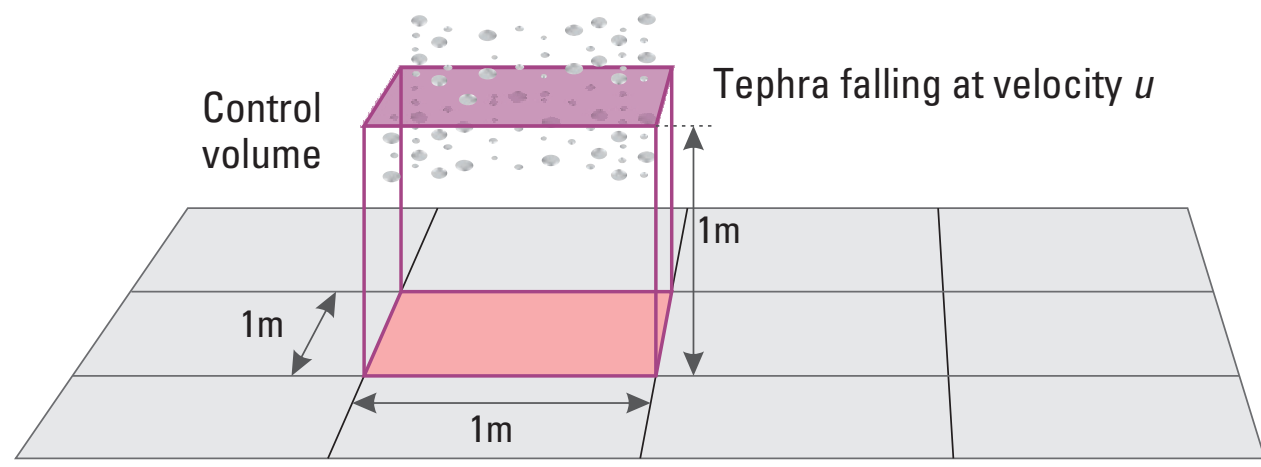

Tephra deposit accumulating at mass rate $\dot{M}_{d}$

Figure 19. Diagram showing control volume into which ash is falling at the mass accumulation rate $\dot{M}_{d}$. The average fall velocity is $u$. Dimension of the grid cells are shown in meters (m).

Table 19. Tabulated fall velocities of ash aggregates from different sources.

[Abbreviations: km, kilometer; kg/m³, kilogram per cubic meter; mm, millimeter; m/s, meter per second; MSH, Mount St. Helens]

\begin{tabular}{ll}
\hline Value & Explanation \\
\hline $1.5 \mathrm{~m} / \mathrm{s}$ & $\begin{array}{c}\text { Estimated by Durant and others (2009) at MSH } 1980 \text { as an average between the cloud (11.5 km) and ground level, based on } \\
\text { a } 1 \text { hour } 46 \text { minute time delay in Spokane between arrival of the cloud overhead and the first tephra-fall. } \\
\text { Velocities of hundreds of falling dry aggregates measured } 7 \mathrm{~km} \text { downwind of Eyjafjallajökull in high-speed video by } \\
\text { Taddeucci and others (2011). Aggregates were mostly } 1 \pm 0.5 \mathrm{~mm} \text { diameter and had densities of }<100 \text { to }>1,000 \mathrm{~kg} / \mathrm{m}^{3} \text {. }\end{array}$ \\
& $\begin{array}{l}\text { Measured by James and others (2002) on loose, dry aggregates created in the laboratory by electrostatically charging } \\
\text { pumice particles. }\end{array}$
\end{tabular}




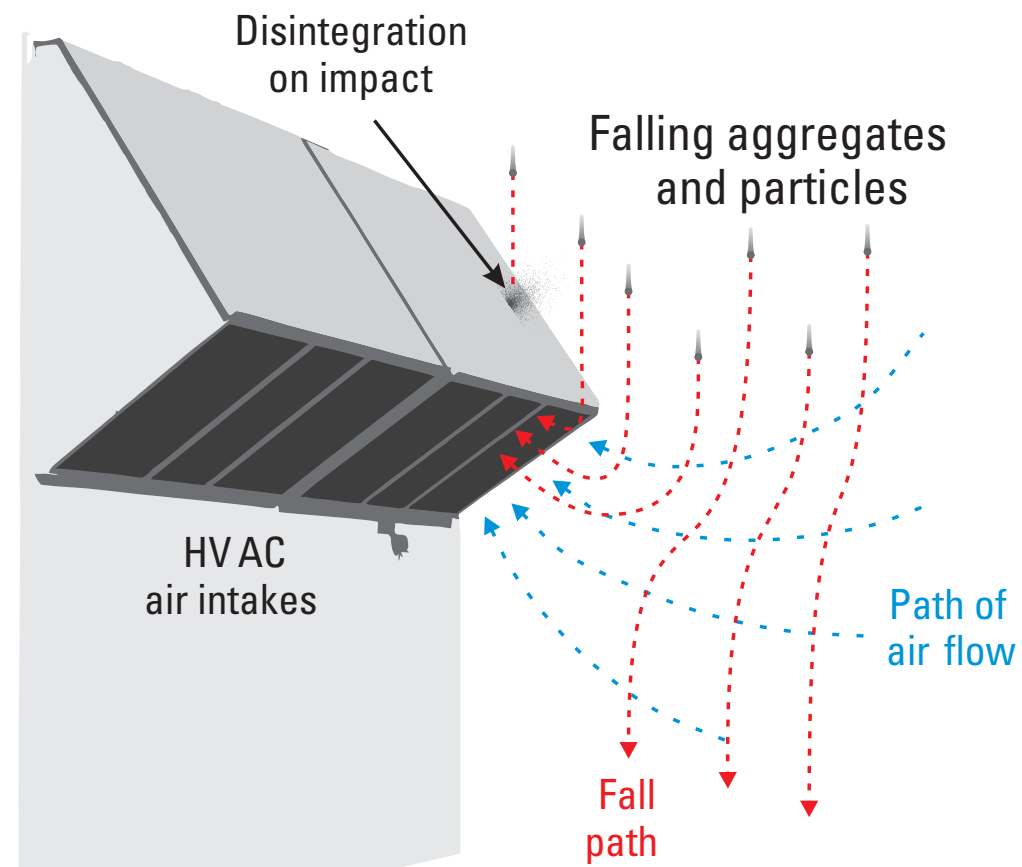

path

\section{Conclusions}

One the basis of about 10,000 model simulations, we estimate maximum and average airborne ash concentrations for the "1 in 10,000-year" event at Hanford, Washington, of about 3,800 and $1,500 \mathrm{mg} / \mathrm{m}^{3}$, respectively. These are order-of-magnitude estimates with large uncertainties, but we are confident that airborne concentrations of about $10^{3} \mathrm{mg} / \mathrm{m}^{3}$ are possible, given known deposit accumulation rates elsewhere. We emphasize that these estimates are of total airborne ash; both falling, and in suspension. They are not comparable to most air quality measurements, which measure only suspended ash.

Falling particles differ from suspended ones in that their movement is no longer well coupled to the air. Air moving toward an HVAC air intake (fig. 20) may not draw them in. The fraction of falling ash ingested depends on the nearby flow field as well as the size, shape, and density of falling material. Some aggregates may disintegrate upon impact (fig. 20), locally increasing the suspended concentration. Assessing the ash ingestion rate into a Hanford HVAC system is beyond the scope of this project. It may involve uncertainties as great as those in this study.

\section{References Cited}

Alfano, F., Bonadonna, C., Delmelle, P., and Costantini, L., 2011, Insights on tephra settling velocity from morphological observations: Journal of Volcanology and Geothermal Research, v. 208, no. 3-4, p. 86-98.
Figure 20. Illustration of the path that might be taken by aggregates or particles falling near the intake of an HVAC system of generic design. Air drag from flow into the intake, along with the gravitational force, will determine whether individual particles or aggregates are ingested. Some aggregates may disintegrate on impact near the intakes, increasing suspended particle concentrations.
Amigo, A., 2013, Estimation of tephra-fall and lahar hazards at Hudson Volcano, southern Chile-Insights from numerical models: Geological Society of America Special Papers, v. 498, p. 177-199.

Arason, P., Peterson, G.N., and Bjornsson, H., 2011, Observations of the altitude of the volcanic plume during the eruption of Eyjafjallajökull, April-May 2010: Earth System Science Data, v. 4, p. 1-25.

Azimi, P., Zhao, D., and Stephens, B., 2014, Estimates of HVAC filtration efficiency for fine and ultrafine particles of outdoor origin: Atmospheric Environment, v. 98,p. 337-346.

Ball, J.G.C., Reed, B.E., Grainger, R.G., Peters, D.M., Mather, T.A., and Pyle, D.M., 2015, Measurements of the complex refractive index of volcanic ash at 450,546.7, and $650 \mathrm{~nm}$ : Journal of Geophysical Research: Atmospheres, v. 120, no. 15 , p. $7,747-7,757$.

Bear-Crozier, A.N., Miller, V., Newey, V., Horspool, N., and Weber, R., 2016, Probabilistic Volcanic Ash Hazard Analysis (PVAHA) I; development of the VAPAH tool for emulating multi-scale volcanic ash fall analysis: Journal of Applied Volcanology, v. 5, no. 1.

Berger, G.W., and Busacca, A.J., 1995, Thermoluminescence dating of late Pleistocene loess and tephra from eastern Washington and southern Oregon and implications for the eruptive history of Mount St. Helens: Journal of Geophysical Research: Solid Earth, v. 100, no. B11, p. 22,361-22,374. 
Berman, R.G., 1988, Internally consistent thermodynamic data for minerals in the system $\mathrm{Na}_{2} \mathrm{O}-\mathrm{K}_{2} \mathrm{O}-\mathrm{CaO}-\mathrm{MgO}-\mathrm{FeO}-$ $\mathrm{Fe}_{2} \mathrm{O}_{3}-\mathrm{Al}_{2} \mathrm{O}_{3}-\mathrm{SiO}_{2}-\mathrm{TiO}_{2}-\mathrm{H}_{2} \mathrm{O}$ : Journal of Petrology, v. 29, p. $445-522$.

Bernstein, R.S., Baxter, P.J., Falk, H., Ing, R., Foster, L., and Frost, F., 1986, Immediate public health concerns and actions in volcanic eruptions; lessons from the Mount St. Helens eruptions, May 18-October 18, 1980: American Journal of Public Health, v. 76, no. Suppl, p. 25-37.

Bonadonna, C., and Houghton, B.F., 2005, Total grain-size distribution and volume of tephra-fall deposits: Bulletin of Volcanology, v. 67, p. 441-456.

Bonadonna, C., Genco, R., Gouhier, M., Pistolesi, M., Cioni, R., Alfano, F., Hoskuldsson, A., and Ripepe, M., 2011, Tephra sedimentation during the 2010 Eyjafjallajökull eruption (Iceland) from deposit, radar, and satellite observations: Journal of Geophysical Research, v. 116, 20 p.

Bonadonna, C., Cioni, R., Pistolesi, M., Elissondo, M., and Baumann, V., 2015a, Sedimentation of long-lasting windaffected volcanic plumes; the example of the 2011 rhyolitic Cordón Caulle eruption, Chile: Bulletin of Volcanology, v. 77 , no. 2 , p. 1-19.

Bonadonna, C., Pistolesi, M., Cioni, R., Degruyter, W., Elissondo, M., and Baumann, V., 2015b, Dynamics of windaffected volcanic plumes: The example of the 2011 Cordón Caulle eruption, Chile: Journal of Geophysical Research: Solid Earth, v. 120, no. 4, p. 2,242-2,261.

Busacca, A.J., Nelstead, K.T., McDonald, E.V., and Purser, M.D., 1992, Correlation of distal tephra layers in loess in the Channeled Scabland and Palouse of Washington state: Quaternary Research, v. 37, no. 3, p. 281-303.

Carazzo, G., and Jellinek, A.M., 2012, A new view of the dynamics, stability and longevity of volcanic clouds: Earth and Planetary Science Letters, v. 325-326, no. 0, p. 39-51.

Carey, S., Gardner, J., and Sigurdsson, H., 1995, The intensity and magnitude of Holocene plinian eruptions from Mount St. Helens volcano: Journal of Volcanology and Geothermal Research, v. 66, p. 185-202.

Carey, S., and Sigurdsson, H., 1982, Influence of particle aggregation on deposition of distal tephra from the May 18, 1980, eruption of Mount St. Helens volcano: Journal of Geophysical Research, v. 87, no. B8, p. 7,061-7,072.

Carey, S., and Sigurdsson, H., 1985, The May 18, 1980, eruption of Mount St. Helens 2-Modeling of dynamics of the Plinian phase: Journal of Geophysical Research, v. 90, no. B4, p. 2,948-2,958.

Carey, S., and Sigurdsson, H., 1989, The intensity of Plinian eruptions: Bulletin of Volcanology, v. 51, no. 1, p. 28-40.
Castro, J., Schipper, C.I., Mueller, S., Militzer, A.S., Amigo, A., Parejas, C., and Jacob, D., 2013, Storage and eruption of near-liquidus rhyolite magma at Cordón Caulle, Chile: Bulletin of Volcanology, v. 75, no. 4, p. 1-17.

Center for Disease Control, 1980, CDC--Mount St. Helens Volcano Health Report \#4, June 6, 1980: Atlanta, GA, U.S. Department of Health and Human Services, p. 3.

Christiansen, R.L., and Peterson, D.W., 1981, Chronology of the eruptive activity, in Lipman, P.W., and Mullineaux, D.R., eds., The 1980 Eruptions of Mount St. Helens, Washington: USGS Professional Paper 1250: Washington, D.C., U.S. Government Printing Office, p. 3-30.

Clarkson, R.J., Majewicz, E.J., and Mack, P., 2016, A reevaluation of the 2010 quantitative understanding of the effects volcanic ash has on gas turbine engines: Proceedings of the Institution of Mechanical Engineers, Part G; Journal of Aerospace Engineering, v. 230, no 12, p. 2,274-2,291.

Clynne, M.A., Calvert, A.T., Wolfe, E.W., Evarts, R.C., Fleck, R.J., and Lanphere, M.A., 2008, The Pleistocene eruptive history of Mount St. Helens, Washington, from 300,000 to 12,800 years before present, in Sherrod, D.R., Scott, W.E., and Stauffer, P.H., eds., A volcano rekindledThe renewed eruption of Mount St. Helens, 2004-2006: U.S. Geological Survey Professional Paper 1750, Washington, D.C., U.S. Government Printing Office, p. 593-627.

Coltice, N., Gérault, M., and Ulvrová, M., 2017, A mantle convection perspective on global tectonics: Earth-Science Reviews, v. 165, p. 120-150.

Coombs, M.L., Sisson, T.W., Bleick, H.A., Henton, S.M., Nye, C.J., Payne, A.L., Cameron, C.E., Larsen, J.F., Wallace, K.L., and Bull, K.F., 2013, Andesites of the 2009 eruption of Redoubt Volcano, Alaska: Journal of Volcanology and Geothermal Research, v. 259, no. 0, p. 349-372.

Criswell, W., 1987, Chronology and pyroclastic stratigraphy of the May 18, 1980 eruption of Mount St. Helens, Washington: Journal of Geophysical Research, v. 92, no. B10, p. 10,237-10,266.

Dartevelle, S., Ernst, G.G.J., Stix, J., and Bernard, A., 2002, Origin of the Mount Pinatubo climactic eruption cloud; Implications for volcanic hazards and atmospheric impacts: Geology, v. 30, no. 7, p. 663-666.

Dee, D.P., Uppala, S.M., Simmons, A.J., Berrisford, P., Poli, P., Kobayashi, S., Andrae, U., Balmaseda, M.A., Balsamo, G., Bauer, P., Bechtold, P., Beljaars, A.C.M., van de Berg, L., Bidlot, J., Bormann, N., Delsol, C., Dragani, R., Fuentes, M., Geer, A.J., Haimberger, L., Healy, S.B., Hersbach, H., Hólm, E.V., Isaksen, L., Kållberg, P., Köhler, M., Matricardi, M., McNally, A.P., Monge-Sanz, B.M., Morcrette, J.J., Park, B.K., Peubey, C., de Rosnay, P., Tavolato, C., Thépaut, J.N., and Vitart, F., 2011, The ERAInterim reanalysis; configuration and performance of the data assimilation system: Quarterly Journal of the Royal Meteorological Society, v. 137, no. 656, p. 553-597. 
Durant, A., and Rose, W.I., 2009, Sedimentological constraints on hydrometeor-enhanced particle deposition; 1992 eruptions of Crater Peak, Alaska: Journal of Volcanology and Geothermal Research, v. 186, no. 1-2, p. 40-59.

Durant, A.J., Rose, W.I., Sarna-Wojcicki, A.M., Carey, S., and Volentik, A.C., 2009, Hydrometeor-enhanced tephra sedimentation-Constraints from the 18 May 1980 eruption of Mount St. Helens [USA]: Journal of Geophysical Research, v. 114, no. B03204.

Etyemezian, V., Gillies, J.A., Mastin, L.G., Crawford, A., Hasson, R., Van Eaton, A.R., and Nikolich, G., 2019, Laboratory experiments of volcanic ash resuspension by wind: Journal of Geophysical Research; Atmospheres, v. 124, no. 16, p. 9,534-9,560.

Evarts, R.C., Ashley, R.P., and Smith, J.G., 1987, Geology of the Mount St. Helens area-Record of discontinuous volcanic and plutonic activity in the Cascade Arc of southern Washington: Journal of Geophysical Research; Solid Earth, v. 92 , no. B10, p. 10,155-10,169.

Fierstein, J., and Hildreth, W., 1992, The plinian eruptions of 1912 at Novarupta, Katmai National Park, Alaska: Bulletin of Volcanology, v. 54, p. 646-684.

Fierstein, J., and Nathenson, M., 1992, Another look at the calculation of fallout tephra volumes: Bulletin of Volcanology, v. 54, p. 156-167.

Gardner, J.E., Carey, S., Sigurdsson, H., and Rutherford, M.J., 1995, Influence of magma composition on the eruptive activity of Mount St. Helens, Washington: Geology, v. 23, no. 6 , p. 523-526.

Genareau, K., Proussevitch, A.A., Durant, A.J., Mulukutla, G., and Sahagian, D.L., 2012, Sizing up the bubbles that produce very fine ash during explosive volcanic eruptions: Geophysical Research Letters, v. 39, no. 15, p. L15306.

Ghiorso, M.S., and Sack, R.O., 1995, Chemical mass transfer in magmatic processes IV-A revised and internally consistent thermodynamic model for the interpolation and extrapolation of liquid-solid equilibria in magmatic systems at elevated temperatures and pressures: Contributions to Mineralogy and Petrology, v. 119, p. 197-212.

Global Volcanism Program, 2013, Volcanoes of the World, v. 4.7.5., Venzke, E., ed.: Smithsonian Institution, accessed January 11, 2019, at https://doi.org/10.5479/si.GVP. VOTW4-2013.

Gonnermann, H.M., and Houghton, B.F., 2012, Magma degassing during the Plinian eruption of Novarupta, Alaska, 1912: Geochemistry, Geophysics, Geosystems, v. 13, no. 10 .
Gordian, M.E., Ozkaynak, H., Xue, J., Morris, S.S., and Spengler, J.D., 1996, Particulate air pollution and respiratory disease in Anchorage, Alaska: Environmental Health Perspectives, v. 104, no. 3, p. 290-297.

Gudmundsson, M.T., Thordarson, T., Hoskuldsson, A., Larsen, G., Bjornsson, H., Prata, A.J., Oddsson, B., Magnusson, E., Hognadottir, T., Peterson, N.G., Hayward, C.L., Stevenson, J.A., and Jonsdottir, I., 2012, Ash generation and distribution from the April-May 2010 eruption of Eyjafjallajökull, Iceland: Scientific Reports, v. 2, no. 572, 20 p., https://doi.org/10.1038/srep00572.

Harris, D.M., Rose, W.I., Roe, R., and Thompson, M.R., 1981, Radar observations of ash eruptions, in Lipman, P.W., and Mullineaux, D.R., eds., The 1980 Eruptions of Mount St. Helens, Washington: U.S. Geological Survey Professional Paper 1250, Washington, D.C., U.S. Government Printing Office, p. 323-333.

Hildreth, W., and Drake, R.E., 1992, Volcán Quizapu, Chilean Andes: Bulletin of Volcanology, v. 54, p. 93-125.

Hildreth, W., and Fierstein, J., 1997, Recent eruptions of Mount Adams, Washington Cascades, USA: Bulletin of Volcanology, v. 58, no. 6, p. 472-490.

Hoblitt, R.P., and Harmon, R.S., 1993, Bimodal density distribution of cryptodome dacite from the 1980 eruption of Mount St. Helens, Washington: Bulletin of Volcanology, v. 55 , p. $421-437$.

Hoblitt, R.P., and Scott, W.E., 2011, Estimate of tephra accumulation probabilities for the U.S. Department of Energy's Hanford Site, Washington: U.S. Geological Survey Open-File Report 2011-1064, p. 15, http://pubs.usgs.gov/ of/2011/1064/.

Holasek, R.E., and Self, S., 1995, GOES weather satellite observations and measurements of the May 18, 1980, Mount St. Helens eruption: Journal of Geophysical Research, v. 100, no. B5, p. 8,469-8,487.

Holasek, R.E., Self, S., and Woods, A.W., 1996, Satellite observations and interpretation of the 1991 Mount Pinatubo eruption plumes: Journal of Geophysical Research, v. 101, no. B12, p. 27,635-27,656.

Hurst, A.W., and Smith, W., 2004, A Monte Carlo methodology for modelling ashfall hazards: Journal of Volcanology and Geothermal Research, v. 138, p. 393-403.

International Atomic Energy Agency, 2016, Volcanic hazard assessments for nuclear installations: Methods and examples in site evaluation: Vienna, International Atomic Energy Agency. 
International Organization for Standardization, 2001, Particle size analysis-Laser diffraction methods, p. 51, https:// www.iso.org/standard/44929.html.

International Organization for Standardization, 2009, Particle size analysis - Laser diffraction methods: International Organization for Standardization ISO 13320:2009, 51 p.

James, M.R., Gilbert, J.S., and Lane, S.J., 2002, Experimental investigation of volcanic particle aggregation in the absence of a liquid phase: Journal of Geophysical Research: Solid Earth, v. 107, no. B9, p. ECV 4-1-ECV 4-13.

James, M.R., Lane, S.J., and Gilbert, J.S., 2003, Density, construction, and drag coefficient of electrostatic volcanic ash aggregates: Journal of Geophysical Research, v. 108, , no. B9, p. 2,435, https://doi.org/10.1029/2002JB002011.

Klug, C., and Cashman, K.V., 1994, Vesiculation of May 18, 1980 Mount St. Helens magma: Geology, v. 22, p. 468-472.

Koyaguchi, T., 1996, Volume estimation of tephra-fall deposits from the June 15, 1991, eruption of Mount Pinatubo by theoretical and geological methods, in Newhall, C.G., and Punongbayan, R.S., eds., Fire and mud-Eruptions and lahars of Mount Pinatubo, Philippines: Seattle, University of Washington Press, p. 583-600.

Koyaguchi, T., and Tokuno, M., 1993, Origin of the giant eruption cloud of Pinatubo, June 15, 1991: Journal of Volcanology and Geothermal Research, v. 55, p. 85-96.

Lange, R.A., 1994, The effect of $\mathrm{H}_{2} \mathrm{O}, \mathrm{CO}_{2}$, and $\mathrm{F}$ on the density and viscosity of silicate melts, in Carroll, M.R., and Holloway, J.R., eds., Volatiles in Magmas: Fredericksburg, VA, BookCrafters, p. 331-369.

LeVeque, R.J., 2002, Finite Volume Methods for Hyperbolic Problems: Cambridge, Cambridge University Press, 553 p.

Liu, E.J., Cashman, K.V., and Rust, A.C., 2015, Optimising shape analysis to quantify volcanic ash morphology: GeoResJ, v. 8, p. 14-30.

Mastin, L.G., Van Eaton, A., and Schwaiger, H., 2020, Data used to develop a probabilistic assessment of tephra-fall hazards at Hanford, Washington, from a future eruption of Mount St. Helens: U.S. Geological Survey Data Release, https://doi.org/10.5066/P9VPFXQR.

Mastin, L.G., Guffanti, M., Servranckx, R., Webley, P., Barsotti, S., Dean, K., Durant, A., Ewert, J.W., Neri, A., Rose, W.I., Schneider, D., Siebert, L., Stunder, B., Swanson, G., Tupper, A., Volentik, A., and Waythomas, C.F., 2009, A multidisciplinary effort to assign realistic source parameters to models of volcanic ash-cloud transport and dispersion during eruptions: Journal of Volcanology and Geothermal Research, v. 186, no. 1-2, p. 10-21.
Mastin, L.G., Randall, M., J., Schwaiger, H., and Denlinger, R., 2013, User's Guide and Reference to Ash3d: A threedimensional model for atmospheric tephra transport and Deposition, U.S. Geological Survey Open-File Report 2,013-1,122, 48 p., https://doi.org/10.3133/ofr20131122.

Mastin, L.G., Van Eaton, A.R., and Durant, A.J., 2016, Adjusting particle-size distributions to account for aggregation in tephra-deposit model forecasts: Atmospheric Chemistry and Physics., v. 16, no. 14, p. 9,399-9,420.

Mastin, L.G., Van Eaton, A.R., and Lowenstern, J.B., 2014, Modeling ash fall distribution from a Yellowstone supereruption: Geochemistry, Geophysics, Geosystems, v. 15, no. 8 , p. 3,459-3,475.

Mastrolorenzo, G., Pappalardo, L., Troise, C., Panizza, A., and De Natale, G., 2008, Probabilistic tephra hazard maps for the Neapolitan area-Quantitative volcanological study of Campi Flegrei eruptions: Journal of Geophysical Research, v. 113, no. B07203, https://doi.org/10.1029/2007JB004954.

Miura, T., Koyaguchi, T., and Tanaka, Y., 2002, Measurements of electric charge distribution in volcanic plumes at Sakurajima Volcano, Japan: Bulletin of Volcanology, v. 64, no. 75.

Morton, B.R., Taylor, G.I., and Turner, J.S., 1956, Turbulent gravitational convection from maintained and instantaneous sources: Proceedings of the Royal Society of London, ser. A, v. 234, p. 1-23.

Mullineaux, D.R., 1974, Pumice and other pyroclastic deposits in Mount Rainier National Park, U.S. Geological Survey Bulletin 1326. [Also available at https://doi.org/10.3133/ b1326.]

Mullineaux, D.R., 1986, Summary of pre-1980 tephra-fall deposits erupted from Mount St. Helens, Washington State, USA: Bulletin of Volcanology, v. 48, p. 17-26.

Mullineaux, D.R., 1996, Pre-1980 tephra-fall deposits erupted from Mount St. Helens, Washington: U.S. Geological Survey Professional Paper 1563, 99 p., [also available at https:// doi.org/10.3133/pp1563].

Nakagawa, M., Wada, K., Thordarson, T., Wood, C.P., and Gamble, J.A., 1999, Petrologic investigations of the 1995 and 1996 eruptions of Ruapehu volcano, New ZealandFormation of discrete and small magma pockets and their intermittent discharge: Bulletin of Volcanology, v. 61, no. $1-2$, p. $15-31$.

Nathenson, M., 2017, Revised tephra volumes for Cascade Range volcanoes: Journal of Volcanology and Geothermal Research, v. 341, p. 42-52. [Also available at https://doi. org/10.1016/j.jvolgeores.2017.04.021.] 
Nathenson, M., Clynne, M.A., and Muffler, L.J.P., 2012, Eruption probabilities for the Lassen Volcanic Center and regional volcanism, northern California, and probabilities for large explosive eruptions in the Cascade Range, U.S. Geological Survey Scientific Investigations Report 20125176B, $30 \mathrm{p}$.

Newhall, C.G., and Self, S., 1982, The volcanic explosivity index/VEI/- An estimate of explosive magnitude for historical volcanism: Journal of Geophysical Research, v. 87.

Nye, C.J., Harbin, M., L., Miller, T.P., Swanson, S.E., and Neal, C.A., 1995, Whole-rock major and trace-element chemistry of the 1992 ejecta from Crater Peak, Mount Spurr, Alaska, in Keith, T.E.C., The 1992 eruptions of Crater Peak Vent, Mount Spurr Volcano, Alaska. U.S. Geological Survey Bulletin 2139: Washington, D.C., U.S. Government Printing Office, p. 119-128.

Paladio-Melosantos, M.L.O., Solidum, R.U., Scott, W.E., Quiambao, R.B., Umbal, J.V., Rodolfo, K.S., Tubianosa, B.S., Delos Reyes, P.J., Alonso, R.A., and Ruelo, H.B., 1996, Tephra Falls of the 1991 eruptions of Mount Pinatubo, in Newhall, C.G., and Punongbayan, R.S., eds., Fire and mud-Eruptions and lahars of Mount Pinatubo, Philippines: Seattle, University of Washington Press, p. 513-536.

Pallister, J.S., Clynne, M.A., Wright, H.M., Van Eaton, A.R., Vallance, J.W., Sherrod, D.R., and Kokelaar, B.P., 2017, Field-trip guide to Mount St. Helens, Washington-An overview of the eruptive history and petrology, tephra deposits, 1980 pyroclastic density current deposits, and the crater: U.S. Geological Survey Scientific Investigations Report 2017-5022, 80 p. [Also available at https://doi. org/10.3133/sir20175022D.]

Pallister, J.S., Hoblitt, R.P., Crandell, D.R., and Mullineaux, D.R., 1992, Mount St. Helens a decade after the 1980 eruptions-Magmatic models, chemical cycles, and a revised hazards assessment: Bulletin of Volcanology, v. 54, p. 126-146.

Roggensack, K., 2001, Unraveling the 1974 eruption of Fuego volcano (Guatemala) with small crystals and their young melt inclusions: Geology, v. 29, no. 10, p. 911-914.

Rose, W.I., and Durant, A., 2009, Fine ash content of explosive eruptions: Journal of Volcanology and Geothermal Research, v. 186, no. 1-2, p. 32-39.

Rose, W.I., Self, S., Murrow, P.J., Bonadonna, C., Durant, A.J., and Ernst, G.G.J., 2008, Nature and significance of small volume fall deposits at composite volcanoes-Insights from the October 14, 1974, Fuego eruption, Guatemala: Bulletin of Volcanology, v. 70, p. 1,043-1,067.
Rutherford, M.J., Sigurdsson, H., Carey, S., and Davis, A., 1985, The May 18, 1980, eruption of Mount St. Helens-1, Melt composition and experimental phase equilibria: Journal of Geophysical Research, v. 90, no. B4, p. 2,929-2,947.

Sarna-Wojcicki, A.M., Shipley, S., Waitt, R., Dzurisin, D., and Wood, S.H., 1981, Areal distribution, thickness, mass, volume, and grain size of air-fall ash from the six major eruptions of 1980, in Lipman, P.W., and Christiansen, R.L., eds., The 1980 eruptions of Mount St. Helens, Washington: U.S. Geological Survey Professional Paper 1250, p. 577-601.

Scheidegger, K.F., Federman, A.N., and Tallman, A.M., 1982, Compositional heterogeneity of tephras from the 1980 eruptions of Mount St. Helens: Journal of Geophysical Research: Solid Earth, v. 87, no. B13, p. 10,861-10,881.

Schwaiger, H., Denlinger, R., and Mastin, L.G., 2012, Ash3d: a finite-volume, conservative numerical model for ash transport and tephra deposition: Journal of Geophysical Research, v. 117, no. B04204, 20 p. https://doi. org/10.1029/2011JB008968.

Scollo, S., Del Carlo, P., and Coltelli, M., 2007, Tephra fallout of 2001 Etna flank eruption: Analysis of the deposit and plume dispersion: Journal of Volcanology and Geothermal Research, v. 160, p. 147-164.

Scott, W.E., and Gardner, C.A., 2017, Field-trip guide to Mount Hood, Oregon, highlighting eruptive history and hazards: Scientific Investigations Report 2017-5022G, 132 p. [Also available at https://doi.org/10.3133/sir20175022G]

Scott, W.E., and McGimsey, R.G., 1994, Character, mass, distribution, and origin of tephra-fall deposits of the 19891990 eruption of Redoubt Volcano, south-central Alaska: Journal of Volcanology and Geothermal Research, v. 62, no. $1-4$, p. 251-272.

Searl, A., Nicholl, A., and Baxter, P.J., 2002, Assessment of the exposure of islanders to ash from the Soufrière Hills volcano, Montserrat, British West Indies: Occupational and Environmental Medicine, v. 59, no. 8, p. 523-531.

Sisson, T., Vallance, J.W., and Pringle, P.T., 2001, Progress made in understanding Mount Rainier's hazards: Eos, v. 82, no. 9, p. 113-120.

Snow, R.L., and Nelson, E.A., 2012, Volcano ashfall loads for the Hanford site: Pacific Northwest National Laboratory Report WHC-SD-GN-ER-30038, 14 p.

Sorem, R.K., 1982, Volcanic ash clusters: Tephra rafts and scavengers: Journal of Volcanology and Geothermal Research, v. 13, p. 63-71.

Sparks, R.S.J., Bursik, M.I., Carey, S.N., Gilbert, J.S., Glaze, L.S., Sigurdsson, H., and Woods, A.W., 1997, Volcanic plumes: Chichester, England, John Wiley \& Sons, 574 p. 
Sparks, R.S.J., Moore, J.G., and Rice, C.J., 1986, The initial giant umbrella cloud of the May 18th, 1980, explosive eruption of Mount St. Helens: Journal of Volcanology and Geothermal Research, v. 28, no. 3-4, p. 257-274.

Stirling, M.W., and Wilson, C.J.N., 2002, Development of a volcanic hazard model for New Zealand: First approaches from the methods of probabilistic seismic hazard analysis: Bulletin of the New Zealand Society for Earthquake Engineering, v. 35, no. 4, p. 266-277.

Sulpizio, R., 2005, Three empirical methods for the calculation of distal volume of tephra-fall deposits: Journal of Volcanology and Geothermal Research, v. 145, p. 315-336.

Suzuki, T., 1983, A Theoretical model for dispersion of tephra, in Shimozuru, D., and Yokoyama, I., eds., Arc Volcanism: Physics and Tectonics: Tokyo, Terra Scientific Publishing Company, p. 95-113.

Taddeucci, J., Scarlato, P., Montanaro, C., Cimarelli, C., Del Bello, E., Freda, C., Andronico, D., Gudmundsson, M.T., and Dingwell, D.B., 2011, Aggregation-dominated ash settling from the Eyjafjallajökull volcanic cloud illuminated by field and laboratory high-speed imaging: Geology, v. 39, no. 9, p. 891-894.

Thorsteinsson, T., Jóhannsson, T., Stohl, A., and Kristiansen, N.I., 2012, High levels of particulate matter in Iceland due to direct ash emissions by the Eyjafjallajökull eruption and resuspension of deposited ash: Journal of Geophysical Research: Solid Earth, v. 117, no. B9, 9 p.
Vance, J.A., Clayton, G.A., Mattinson, J.M., and Naeser, C.W., 1987, Early and middle Cenozoic stratigraphy of the Mount Rainier-Tieton River area, southern Washington Cascades, in Schuster, J.E., ed., Selected papers on the Geology of Washington: Washington Division of Geology and Earth Resources Bulletin 77, p. 269-290.

Webb, P.A., 2004, The perserverence of the sedigraph method off particle sizing, Micrometrics Report, accessed September 20, 2019, at http://www.micromeritics.com/ Repository/Files/sedigraph_method.pdf

Westgate, J.A., 1977, Identification and significance of late Holocene tephra from Otter Creek, southern British Columbia, and localities in west-central Alberta: Canadian Journal of Earth Sciences, v. 14, no. 11, p. 2,593-2,600.

Wilson, L., and Huang, T.C., 1979, The influence of shape on the atmospheric settling velocity of volcanic ash particles: Earth and Planetary Science Letters, v. 44, p. 311-324.

Wilson, L., Sparks, R.S.J., Huang, T.C., and Watkins, N.D., 1978, The control of volcanic column heights by eruption energetics and dynamics: Journal of Geophysical Research, v. 83 , no. B4, p. 1,829-1,836.

Zoltai, S.C., 1989, Late Quaternary volcanic ash in the peatlands of central Alberta: Canadian Journal of Earth Sciences, v. 26, p. 207-214. 


\section{Appendix 1: Particle Characterization}

\section{Introduction}

The purpose of this appendix is to characterize the size and shape of volcanic ash particles that could affect Hanford from a future eruption, and to provide supporting data for related modeling and experimental studies on ashfall and resuspension. A careful analysis of particle size and shape would not be necessary if volcanic ash were composed of smooth, uniform spheres akin to beach sand. But the reality is somewhat more complex. For example, ash from explosive eruptions like the May 18th, 1980 eruption of Mount St.
Helens (MSH) consists of fragments of silicate glass, denser mineral crystals, and pieces of host rock blown out by the eruption. These components are present in varying proportions depending on the eruption dynamics and transport history, leading to a complex distribution of sizes and shapes at any given site (fig. 1.1). Here, we characterize some of the key physical properties that influence the aerodynamic properties of volcanic ash, and their entrapment by air intake filters, focusing on particle size and shape. We have analyzed samples of volcanic ash sourced from three primary locations: (1) the proximal MSH 1980 deposit, (2) distal MSH 1980 deposit,

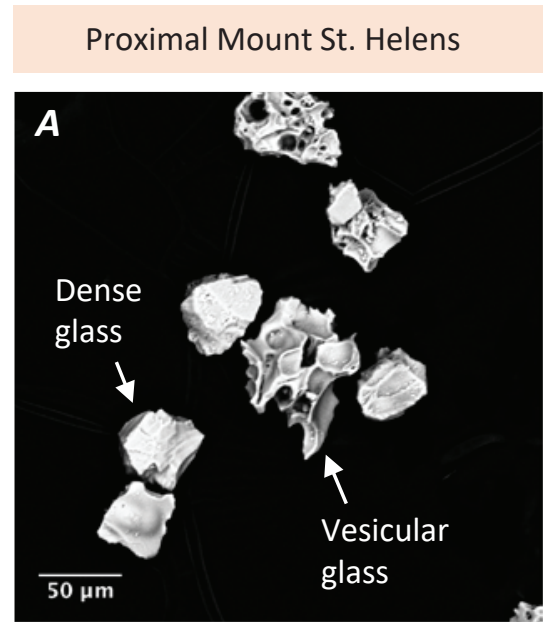

Distal Mount St. Helens (Yakima)
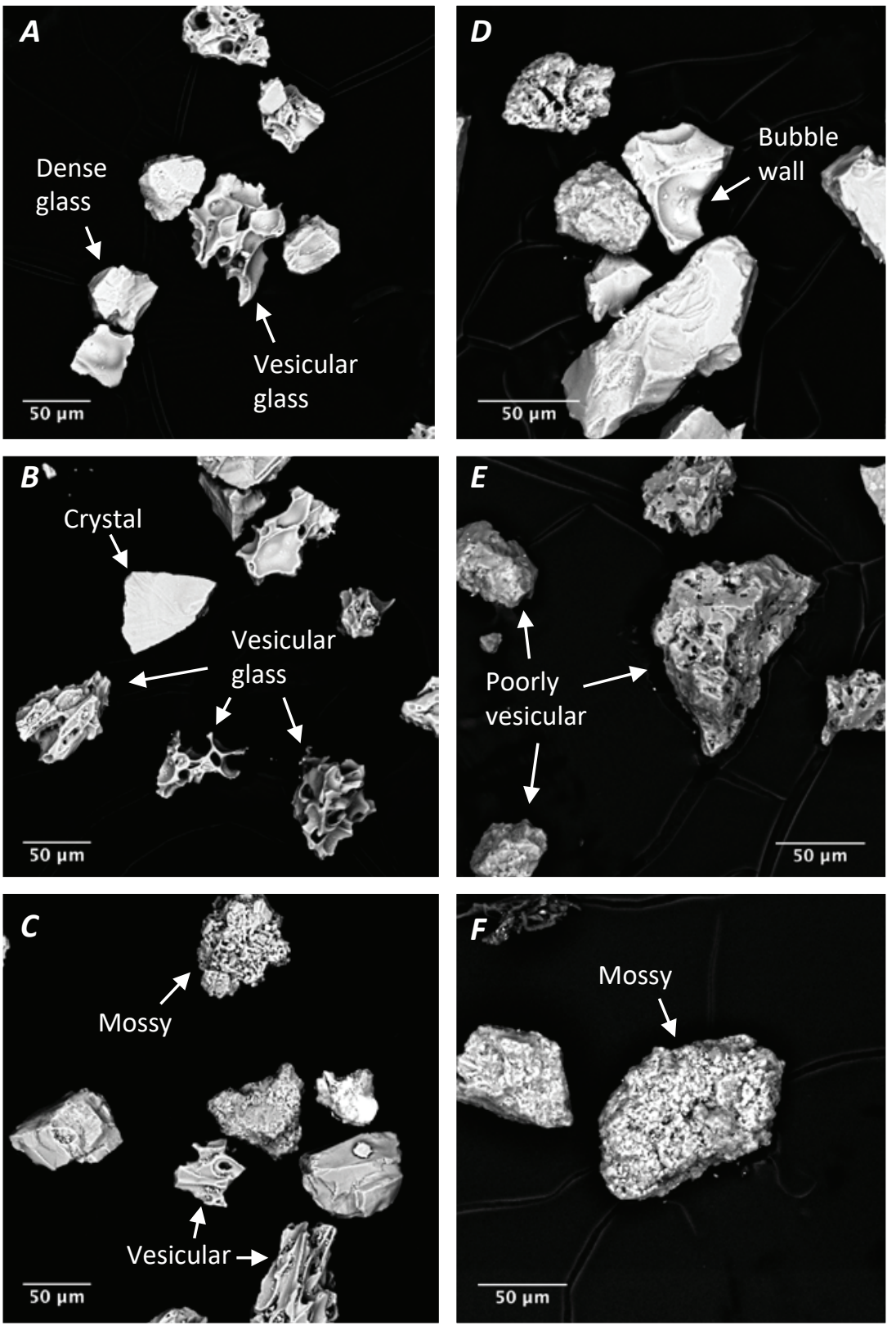
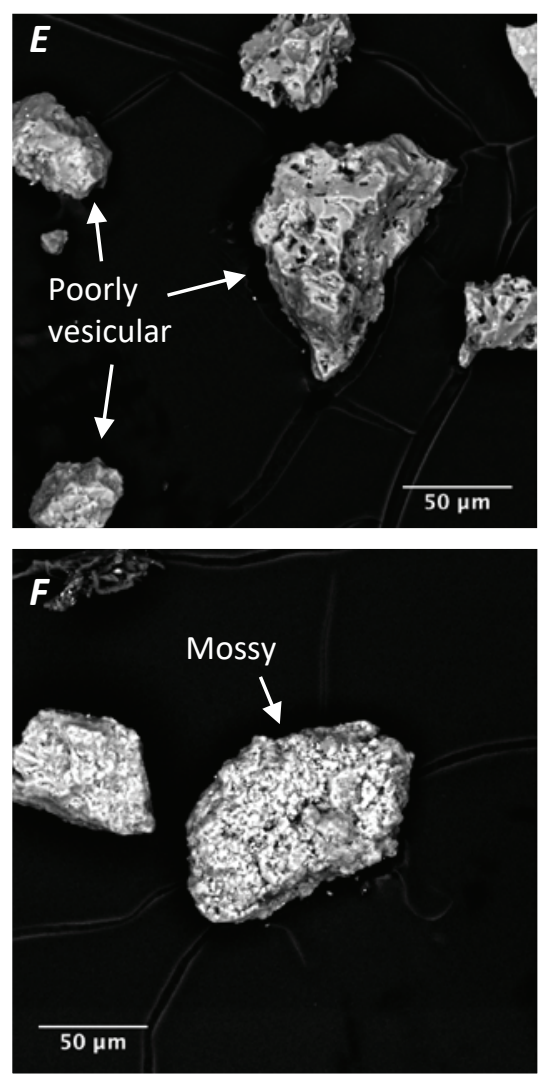

\section{Valley of Ten Thousand Smokes}
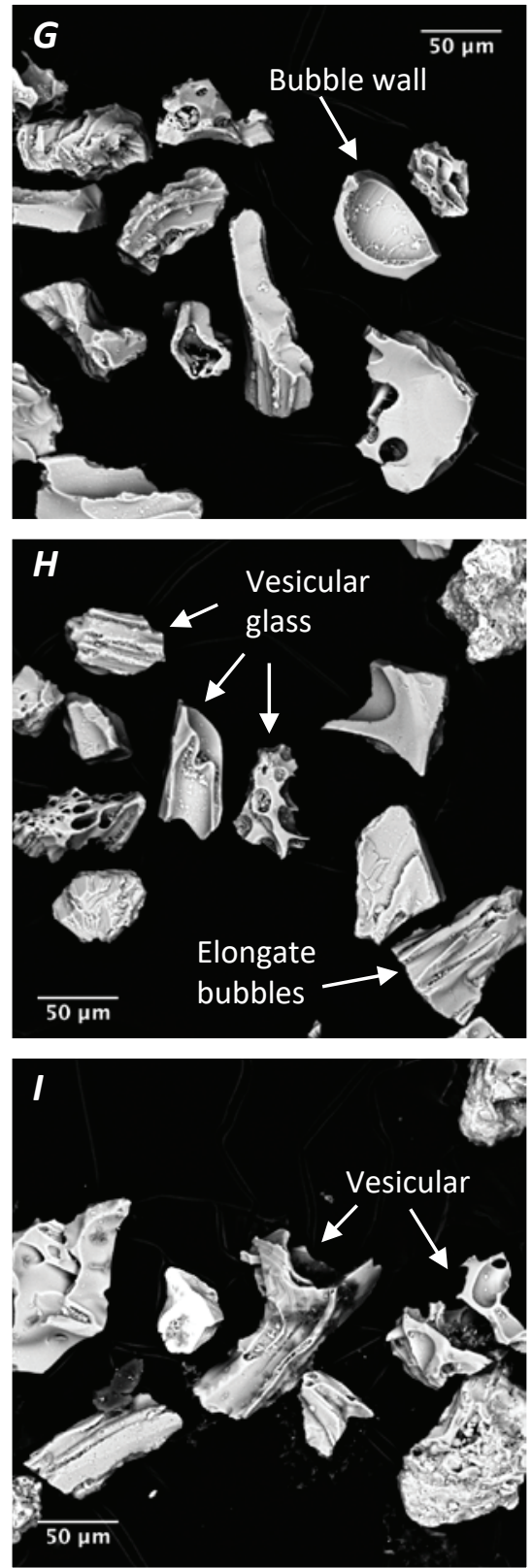
and (3) 1912 Novarupta-Katmai eruption from Alaska's Valley of Ten Thousand Smokes (VTTS). These samples span a range of eruption and transport styles yet are all within the plausible range of Cascades eruptive activity and are all dacitic in composition. This approach allows us to address a key question in context with the modeling and experimental work - what ranges of particle sizes and shapes would we expect to fall at Hanford during the next highly explosive eruption in the Cascades?

\section{Methods and Data}

To address the issues described above, particle size distributions were analyzed for 10 samples of volcanic ash, 3 of which were selected for additional shape analysis (table 1.1, fig. 1.2). All analyses were completed at the U.S. Geological Survey Cascades Volcano Observatory in Vancouver, Wash., by Alexa Van Eaton (laser diffraction, shape analysis) and Katherine Norton (sieve, sedigraph).

Table 1.1. Volcanic ash samples used in particle characterization.

[Collection locations give latitude and longitude in decimal degrees. Abbreviations: DRI, Desert Research Institute; km, kilometer]

\begin{tabular}{|c|c|c|c|}
\hline Sample ID & Analyses & Collection location & Description \\
\hline MSH-B1sub & $\begin{array}{l}\text { sieve, sedigraph, } \\
\text { laser, shape }\end{array}$ & $\begin{array}{l}\text { Mount St. Helens, Wash., } \\
46.26957,-122.18092\end{array}$ & $\begin{array}{l}\text { Field sample from the "ramp" } 8 \mathrm{~km} \text { north of Mount St. Helens, } \\
\text { derived from pyroclastic flows on the afternoon of May 18, } 1980\end{array}$ \\
\hline SUBVTTS2a & $\begin{array}{l}\text { sieve, sedigraph, } \\
\text { laser, shape }\end{array}$ & $\begin{array}{l}\text { Katmai, Alaska } \\
58.40150,-155.38569\end{array}$ & —as above \\
\hline SUBVTTS4a & $\begin{array}{l}\text { sieve, sedigraph, } \\
\text { laser }\end{array}$ & $\begin{array}{l}\text { Katmai, Alaska } \\
58.29762,-155.23869\end{array}$ & —as above, $10 \mathrm{~km}$ from Novarupta \\
\hline SUBVTTS5a & $\begin{array}{l}\text { sieve, sedigraph, } \\
\text { laser }\end{array}$ & $\begin{array}{l}\text { Katmai, Alaska } \\
58.35327,-155.30924\end{array}$ & - as above, $18 \mathrm{~km}$ from Novarupta \\
\hline MSH-Hop_3.17.2017 & laser & DRI lab & Lab sample of ash resuspended during experiments on MSH material \\
\hline $\begin{array}{l}\text { VTTS_ } \\
\text { Hop_3.21.2017 }\end{array}$ & laser & DRI lab & $\begin{array}{l}\text { Lab sample of ash resuspended during experiments on VTTS1, } \\
\text { VTTS2, and VTTS5 material }\end{array}$ \\
\hline $\begin{array}{l}\text { MSH1980-C. } \\
\text { RUSSELL }\end{array}$ & laser, shape & $\begin{array}{l}\text { Yakima, WA } \\
46.60202,-120.41813\end{array}$ & $\begin{array}{l}\text { Field sample of ashfall collected on May 18, 1980, during the first } \\
\text { few hours of ashfall, } 144 \mathrm{~km} \text { from Mount St. Helens }\end{array}$ \\
\hline
\end{tabular}

Figure 1.1 (page 39). Example of scanning electron microscope (SEM) images of volcanic ash used in this study. Arrows point to particle morphologies discussed in the text. Note scale bar on each image; magnification ranges from 270x to 370x. $A-C$, Images of proximal Mount St. Helens (MSH) ash deposit derived from pyroclastic flows on the afternoon of May 18, 1980, (sample MSHb1sub). Note the variety of grains present, from vesicular glass (containing abundant bubbles), to poorly vesicular or dense glass, and a smaller proportion of irregular, mossy grains. D-F, Images of distal MSH ashfall from May 18, 1980, collected from Yakima, Washington, roughly 78 kilometers west of Hanford, Washington (sample MSH1980-C.RUSSELL). This material contains less vesicular glass overall. G-I, Volcanic ash from the Valley of Ten Thousand Smokes, Alaska, derived from tephra-fall deposits of the 1912 Novarupta-Katmai eruption (sample subVTTS2a). Note the abundance of vesicular glass and bubble wall shards. $\mu \mathrm{m}$, micrometer. 


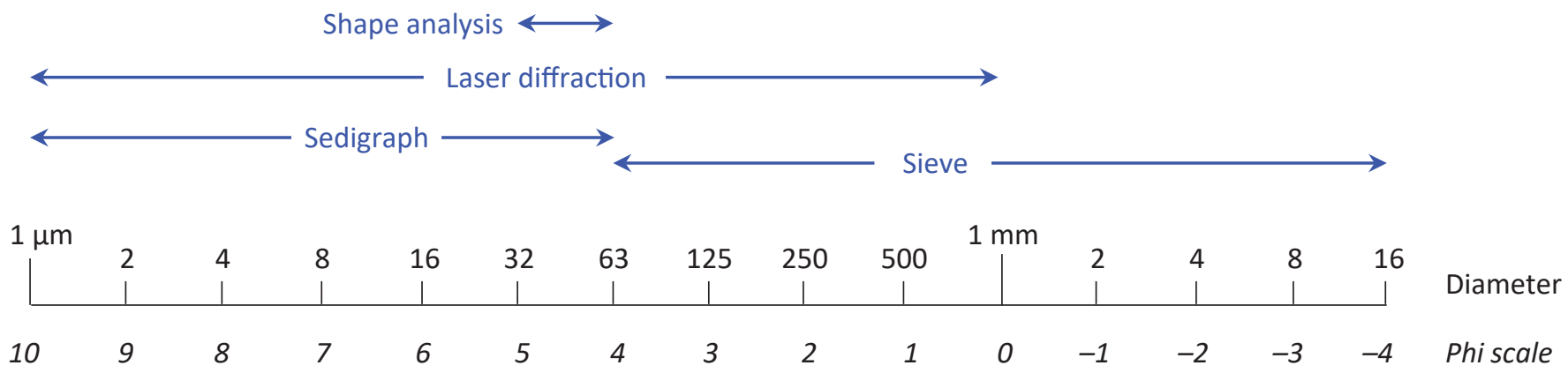

Figure 1.2. Schematic showing the particle characterization methods used on different sizes for this study. Note size bins are based on a logarithmic phi scale $(\varnothing)$ shown in italics, where $\varnothing=-\log _{2}(D)$, and $D$ is the particle diameter in millimeters (mm) and micrometers $(\mu \mathrm{m})$.

\section{Size Analysis of Volcanic Ash}

In conventional methods of particle size analysis, the coarser material is assessed by sieving, which involves passing the sample through progressively smaller meshes and weighing the fractions retained. This approach becomes unreliable for particles much smaller than about 63 micrometers $(\mu \mathrm{m})$, so more sophisticated methods are required for the fine-grained material. In this study we have used a combination of laser diffraction and sedigraph to analyze the finer particles and merge results with sieve data where appropriate. Both laser diffraction and sedigraph have strengths and weaknesses. One benefit of the sedigraph is that it measures settling velocities of particles (in water), which may provide useful information for calculating settling velocities in air. Key benefits of laser diffraction are that it can cover a wider range of sizes $(0.4 \mu \mathrm{m}$ to 2 millimeters $[\mathrm{mm}]$ ) and analyze very small amounts of sample (typically less than 0.2 grams [g]). Results from these two methods would be identical if the particles were perfect spheres with uniform densities and optical properties. But the natural complexity of volcanic ash means that sieving, laser diffraction, and sedigraph techniques each provide slightly different measurements of "diameter", despite being robust and established methods that have been used in particle size analysis for decades.

\section{Sieving}

All samples containing particles larger than $1 \mathrm{~mm}$ were dry sieved (table 1.1) to obtain the distribution of sieve diameters from $31.5 \mathrm{~mm}$ to $63 \mu \mathrm{m}$. To prepare the sample, aggregates were lightly crushed with a mortar and rubber-tipped pestle. The material larger than $4 \mathrm{~mm}$ was hand-sieved at standard intervals of 8,16 , and $31.5 \mathrm{~mm}$. Then the fraction finer than $4 \mathrm{~mm}$ was passed through a stack of sieves using an automated shaker for $10 \pm 2$ minutes, using sieve meshes of $2 \mathrm{~mm}$, $1 \mathrm{~mm}, 500 \mu \mathrm{m}, 250 \mu \mathrm{m}, 125 \mu \mathrm{m}$, and $63 \mu \mathrm{m}$, plus a catch pan. Material retained on each sieve and pan was weighed to the nearest 0.1 gram. The cumulative particle size distribution was recorded as weight percent retained by each sieve and merged with fines analysis where appropriate (table 1.1), as described in the following sections.

\section{Laser diffraction}

Laser diffraction measures the optical diameters of particles less than $2 \mathrm{~mm}$. For this study, the method was only applied to volcanic ash sieved below $1 \mathrm{~mm}$, using a Beckman Coulter LS 13 320. The technique works by shining a $780 \mathrm{~nm}$ laser beam through a well-mixed dispersion of particles in water. The cross sectional areas of tumbling particles scatter the light into a diffraction pattern, which can be converted to a size distribution using Mie theory and some assumptions about the optical properties of the grains. With our instrument configuration, a sample mass of $0.1-0.2 \mathrm{~g}$ is typically enough for a standard analysis. This enabled analysis of the airborne material collected from resuspension experiments in the lab (table 1.1), which did not provide enough material for the sedigraph. To prepare the sample, a test portion of volcanic ash smaller than $1 \mathrm{~mm}$ was transferred to a plastic vial with 50-100 milliliters ( $\mathrm{ml}$ ) of Calgon solution and shaken by hand to disperse any aggregates. Using a plastic pipette, the dispersion was transferred to the instrument's Aqueous Liquid Module and sonicated for $60 \mathrm{sec}$ before analysis. The sample was analyzed 3 times for 60 seconds each, and an average of the three runs was used. A single optical model was applied to all volcanic ash samples used in this study (all are dacitic in composition), using values of 1.5 for the real refractive index and 0.0005 for the absorption coefficient based on comparison with published studies (Ball and others, 2015) and the International Organization for Standardization (ISO) lookup table (ISO, 2009). The results give volume percent finer for each size class. Note that laser diffraction measures volume rather than weight percent (like sieving and sedigraph), but results are comparable if a constant particle density is assumed. For samples that were sieved (table 1.1), the laser diffraction and sieve data were combined by scaling the laser diffraction results to the whole sample using the 
known proportion of ash smaller than $1 \mathrm{~mm}$ determined from sieving. Data are provided in table 1.2. We have binned the laser data into half-phi intervals (see fig. 1.2) although higher-resolution bins are also available in the data archive. We included additional size classes at 2.5 and 10 micrometers (particulate matter $[\mathrm{PM}] 2.5$ and PM10, respectively) because of their relevance to resuspension and air filtration systems (highlighted rows in table 1.2).

\section{Sedigraph}

Sedigraph analysis was performed on all the sieved samples (table 1.1). This method determines the settling diameter of particles less than $63 \mu \mathrm{m}$ by measuring their gravitational fall velocity in water and assuming perfectly spherical shapes. The Micromeritics SediGraph III 5120 uses the relative absorption of a low-energy X-ray beam to estimate the concentration of particles in suspension at different heights, at known times during the analysis. Conversion to a particlesize distribution is performed through a combination of Beer's Law and Stokes' Law, assuming a constant particle density of 2.615 grams per cubic centimeter $\left(\mathrm{g} / \mathrm{cm}^{3}\right)$ and water temperature of $35^{\circ} \mathrm{C}$ (refer to ISO, 2001; Webb, 2004). The analysis requires 1.5 to $3 \mathrm{~g}$ of material for reliable results. To prepare the sample, a sufficient mass of the fraction finer than $63 \mu \mathrm{m}$ fraction was placed in a cup, wetted with deionized water and dispersed using 1 milliliter $(\mathrm{mL})$ of dispersing agent and a 30 second burst with an ultrasonic probe. Then the dispersion was

Table 1.2. Particle-size distributions using combined sieve-laser diffraction analyses, shown as cumulative percent less than a given size fraction.

[Size bins are given in half-phi intervals from 1 micrometer $(\mu \mathrm{m})$ to 1 millimeter $(\mathrm{mm})$, and whole-phi intervals from 1-16 mm. Extra bins were added for PM10 and PM2.5]

\begin{tabular}{|c|c|c|c|c|c|c|c|c|c|c|c|}
\hline Method & $\begin{array}{c}\text { Diameter, } \\
\text { in } \mu \mathrm{m}\end{array}$ & $\begin{array}{l}\text { MSH- } \\
\text { B1sub }\end{array}$ & $\begin{array}{c}\text { subVTT- } \\
\text { S1a }\end{array}$ & $\begin{array}{l}\text { subVTT- } \\
\text { S2a }\end{array}$ & $\begin{array}{c}\text { subVTT- } \\
\text { S3a }\end{array}$ & $\begin{array}{c}\text { subVTT- } \\
\text { S4a }\end{array}$ & $\begin{array}{c}\text { subVTT- } \\
\text { S5a }\end{array}$ & $\begin{array}{c}\text { subVTT- } \\
\text { S6a }\end{array}$ & $\begin{array}{c}\text { MSH_ } \\
\text { Hopper }\end{array}$ & $\begin{array}{l}\text { VTTS_ } \\
\text { Hop_3 }\end{array}$ & $\begin{array}{l}\text { MSH1980- } \\
\text { C.RUSSELL }\end{array}$ \\
\hline laser & 1 & 0.0 & 0.0 & 0.0 & 0.0 & 0.0 & 0.0 & 0.0 & 0.0 & 0.0 & 0.1 \\
\hline laser & 2 & 0.4 & 0.1 & 0.1 & 0.2 & 0.3 & 0.1 & 0.1 & 2.1 & 1.1 & 0.9 \\
\hline laser & 2.5 & 1.5 & 0.3 & 0.2 & 0.9 & 1.1 & 0.1 & 0.1 & 9.4 & 6.5 & 2.0 \\
\hline laser & 3.9 & 6.1 & 0.9 & 0.5 & 3.8 & 4.7 & 0.2 & 0.3 & 37.7 & 30.0 & 5.5 \\
\hline laser & 5.5 & 10.9 & 1.4 & 0.8 & 6.8 & 8.2 & 0.4 & 0.4 & 59.7 & 50.0 & 8.7 \\
\hline laser & 7.8 & 16.6 & 2.0 & 1.1 & 10.1 & 12.2 & 0.5 & 0.6 & 75.1 & 66.0 & 12.1 \\
\hline laser & 10 & 21.6 & 2.4 & 1.4 & 12.8 & 15.4 & 0.6 & 0.8 & 82.7 & 74.9 & 14.7 \\
\hline laser & 11 & 23.6 & 2.6 & 1.5 & 14.0 & 16.8 & 0.7 & 0.8 & 85.0 & 77.8 & 15.8 \\
\hline laser & 31.3 & 53.5 & 5.7 & 3.5 & 33.0 & 38.9 & 2.0 & 2.2 & 99.0 & 97.9 & 28.3 \\
\hline laser & 44.2 & 63.0 & 8.1 & 5.3 & 41.9 & 48.5 & 3.1 & 3.5 & 100.0 & 99.9 & 32.1 \\
\hline laser & 62.5 & 71.3 & 12.3 & 8.7 & 51.6 & 58.7 & 4.7 & 5.6 & 100.0 & 100.0 & 35.0 \\
\hline laser & 88.4 & 78.1 & 18.5 & 14.2 & 60.2 & 67.4 & 7.2 & 9.0 & 100.0 & 100.0 & 37.8 \\
\hline laser & 125 & 84.5 & 27.4 & 22.5 & 68.1 & 74.9 & 10.7 & 13.8 & 100.0 & 100.0 & 41.5 \\
\hline laser & 176.8 & 89.8 & 38.7 & 33.6 & 74.6 & 80.7 & 15.7 & 20.6 & 100.0 & 100.0 & 51.9 \\
\hline laser & 250 & 93.8 & 52.3 & 47.6 & 80.2 & 85.0 & 23.9 & 30.6 & 100.0 & 100.0 & 74.2 \\
\hline laser & 353.6 & 96.6 & 66.1 & 62.1 & 84.9 & 88.6 & 36.8 & 44.7 & 100.0 & 100.0 & 90.9 \\
\hline laser & 500 & 97.7 & 76.7 & 74.0 & 89.2 & 92.0 & 54.4 & 61.4 & 100.0 & 100.0 & 97.3 \\
\hline sieve & 16,000 & 100.0 & 100.0 & 100.0 & 100.0 & 100.0 & 100.0 & 100.0 & 100.0 & 100.0 & 100.0 \\
\hline
\end{tabular}


introduced to the sedigraph for analysis. Recorded values for the mass of each size class were scaled to the whole sample using the known proportion of ash smaller than $63 \mu \mathrm{m}$ determined from sieving (table 1.3).

\section{Shape Analysis of Volcanic Ash}

Particle morphology exerts a first-order control on the aerodynamic behavior of volcanic ash (Wilson and Huang, 1979). The particle sizes most likely to clog HVAC filters are in the range of 10 micrometers diameter and smaller (For example, Azimi and others, 2014). Particles in this size range are challenging to isolate and work with in the lab owing to the effects of electrostatic attraction in low-humidity environments (Miura and others, 2002; James and others, 2003). In our analysis, the $32-63 \mu \mathrm{m}$ fraction was chosen as a reasonable compromise between imaging the finest particles and ensuring reliable results by minimizing electrostatic aggregation and touching grains during sample preparation.

Some of the useful ways to categorize particle shape include measurements of form (elongate versus equant) and roughness (jagged versus smooth) (Liu and others, 2015). To quantify the relevant parameters (table 1.4), we examined twodimensional projected areas of unpolished grains using images from a scanning electron microscope. The areas are projected because they are based on two-dimensional images of complex three-dimensional objects, rather than flat thin sections or polished surfaces (fig. 1.3). This approach was chosen because it allows examination of the surface features and a better intuition for the overall appearance of volcanic ash in its natural state.
Bulk ash samples were sieved between $32-63 \mu \mathrm{m}$, sonicated in deionized water for 2-3 minutes to remove adhering fines, and oven dried. Particles were dusted onto pin-type scanning electron microscope (SEM) stubs and carbon coated using a Denton Vacuum Desk Sputter Coater. Typical SEM operating conditions used a working distance of 15-17 mm and accelerating voltage of 20 kilovolts $(\mathrm{kV})$ in backscatter mode. Images were collected at a magnification of $55 \mathrm{x}$ or more and saved as 1024 x 1024 TIFF files, providing about $20-40$ grains per image and a resolution of at least 0.63 pixels per $\mu \mathrm{m}$. Then images were processed using digital thresholding to distinguish the particles from background. Where necessary, a line was manually drawn (2 pixels wide) to separate touching grains and those touching the edge of the image but still greater than 98 percent within the field of view. Next, the image was converted to binary (black and white) and used as input for ImageJ (software version 1.50c4). Within ImageJ, the scale was specified according to the pixel resolution of the image, and the following measurement routines enabled: (1) area, (2) shape descriptors, (3) perimeter, (4) fit ellipse, and (5) feret diameter (table 1.4). Particles were excluded from analysis if they were less than 200 square micrometers $\left(\mu \mathrm{m}^{2}\right)$ area or touching the edges of the processed image. Resulting outlines were numbered and saved. More than 1,000 particles were analyzed from each of the three samples. The number of pixels per particle (pixel density) is an important factor in data quality, with previous studies showing consistent results with at least 750 pixels per particle (Liu and others, 2015). Therefore, we only include results from the particles defined by 750 pixels or more (table 1.5).

Table 1.3. Sieve-sedigraph particle-size distributions, shown as cumulative weight percent less than a given size fraction.

[Size classes are binned into whole-phi intervals from 1 micrometer $(\mu \mathrm{m})$ to 16 millimeters (mm), (see fig. 1.2). (-) indicates negative values that were rounded up to zero]

\begin{tabular}{lcccccccc}
\hline Method & $\begin{array}{c}\text { Diameter, in } \\
\boldsymbol{\mu m}\end{array}$ & MSH-B1sub & subVTTS1a & subVTTS2a & subVTTS3a & subVTTS4a & subVTTS5a & subVTTS6a \\
sedigraph & 1 & 0.9 & 0.1 & - & 4.0 & 5.4 & - & 0.1 \\
sedigraph & 2 & 4.9 & 0.3 & 0.4 & 6.3 & 7.6 & 0.3 & 0.3 \\
sedigraph & 3.9 & 10.0 & 0.5 & 0.5 & 8.3 & 10.3 & 0.4 & 0.4 \\
sedigraph & 7.8 & 21.8 & 1.1 & 1.2 & 11.8 & 15.0 & 0.9 & 0.9 \\
sedigraph & 15.6 & 41.3 & 2.4 & 2.1 & 17.5 & 23.5 & 1.7 & 1.6 \\
sedigraph & 31.3 & 57.9 & 6.8 & 5.7 & 27.0 & 36.6 & 4.3 & 3.9 \\
sieve & 62.5 & 67.7 & 13.7 & 11.7 & 33.0 & 43.6 & 8.5 & 8.0 \\
sieve & 125 & 85.0 & 32.8 & 31.1 & 48.4 & 59.8 & 19.5 & 18.9 \\
sieve & 250 & 94.7 & 60.1 & 60.8 & 62.2 & 72.6 & 40.3 & 39.3 \\
sieve & 500 & 98.1 & 81.7 & 82.2 & 81.9 & 87.2 & 72.9 & 71.6 \\
sieve & 1,000 & 98.9 & 90.4 & 89.8 & 95.7 & 97.4 & 89.4 & 90.3 \\
sieve & 2,000 & 99.6 & 95.4 & 96.0 & 99.4 & 99.1 & 94.1 & 95.4 \\
sieve & 4,000 & 100.0 & 97.9 & 98.8 & 99.9 & 100.0 & 96.6 & 97.2 \\
sieve & 8,000 & 100.0 & 99.2 & 99.9 & 100.0 & 100.0 & 98.3 & 97.9 \\
sieve & 16,000 & 100.0 & 100.0 & 100.0 & 100.0 & 100.0 & 100.0 & 100.0 \\
\hline
\end{tabular}



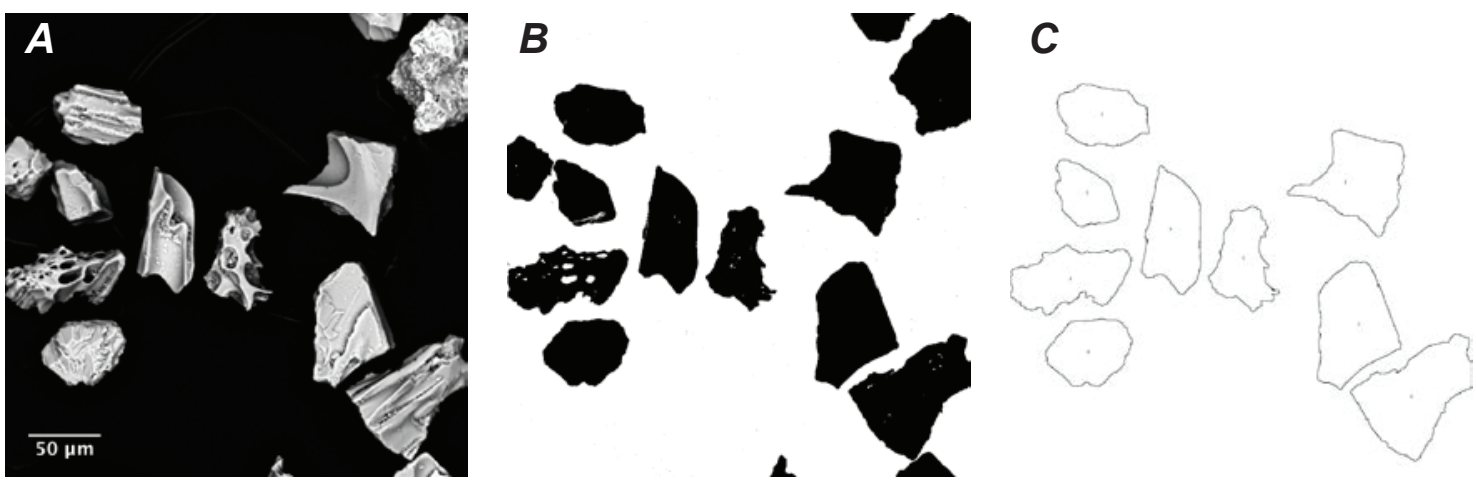

Figure 1.3. Images showing steps of particle-shape analysis. $A$, Original scanning electron microscope (SEM) image in backscatter mode. $B$, Processed image used as input for ImageJ analysis, after thresholding the particles and converting to black and white. C, Output image showing the outlines included in analysis. Within the software file, each particle outline is numbered, giving it a unique reference ID. $\mu \mathrm{m}$, micrometer.

Table 1.4. Particle shape descriptors used in this study.

\begin{tabular}{ll}
\hline Area & Area of particle within outline, including bubbles \\
Perimeter & Length of the outside boundary of the particle \\
Major & Major axis of a best fit ellipse \\
Minor & Minor axis of a best fit ellipse \\
Circularity & $4 \pi \times[\text { Area/Perimeter }]^{2}$ with a value of 1.0 indicating a perfect circle \\
Feret & Maximum caliper, the longest distance between any two points on particle boundary \\
MinFeret & Minimum caliper, the shortest distance between any two points on particle boundary \\
Aspect ratio & Ratio of long to short axes (Major / Minor) \\
Roundness & $4 \times$ Area / $\left(\pi \times\right.$ Major $\left.{ }^{2}\right)$ \\
Solidity & Morphological roughness (Area / Area of a convex hull) \\
Pixel density & Number of pixels contained within the particle \\
Form Factor & Measure of form and roughness ( $\pi \times$ Area/Perimeter $\left.{ }^{2}\right)$ \\
Axial ratio & Ratio of intermediate to long axes $($ Minor $/$ Major) \\
\hline
\end{tabular}

Table 1.5. Samples and number of particles used in shape analysis.

[Sample ID corresponds to table 1.1. Note that only particles defined by 750 pixels or more were included in results]

\begin{tabular}{llcr}
\hline \multicolumn{1}{c}{ Sample ID } & \multicolumn{1}{c}{ Location } & Particles analyzed & Particles of $\geq$ 750-pixel density \\
\hline MSHB1-sub & Mount St. Helens, Wash. & 1,601 & 1,029 \\
MSH1980-C.RUSSELL & Yakima, Wash. & 1,640 & 1,087 \\
subVTTS2a & Katmai, Alaska & 1,004 & 815 \\
\hline
\end{tabular}

\section{Results and Discussion}

\section{Particle-Size Distributions}

Full results of the measured size distributions are tabulated in spreadsheet A1 in the accompanying data repository (Mastin and others, 2020). Size distributions of the volcanic ash from Mount St. Helens and Valley of
Ten Thousand Smokes samples show several key features (fig. 1.4). First, the 10 samples of primary volcanic ash show marked variations in the content of particles less than or equal to $10 \mu \mathrm{m}$ (PM10), from less than one percent in the coarsest samples from the Valley of Ten Thousand Smokes, to 22 percent in the proximal MSH sample. Particles smaller than 2.5 $\mu \mathrm{m}$ (PM2.5) range from 0.2-2 percent (fig. 1.4, table 1.2). In contrast, the airborne ash collected during resuspension 
Mount St. Helens, Washington

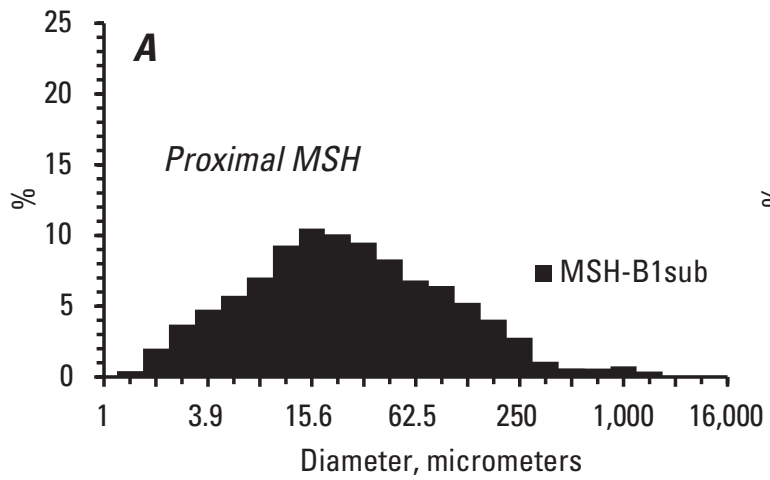

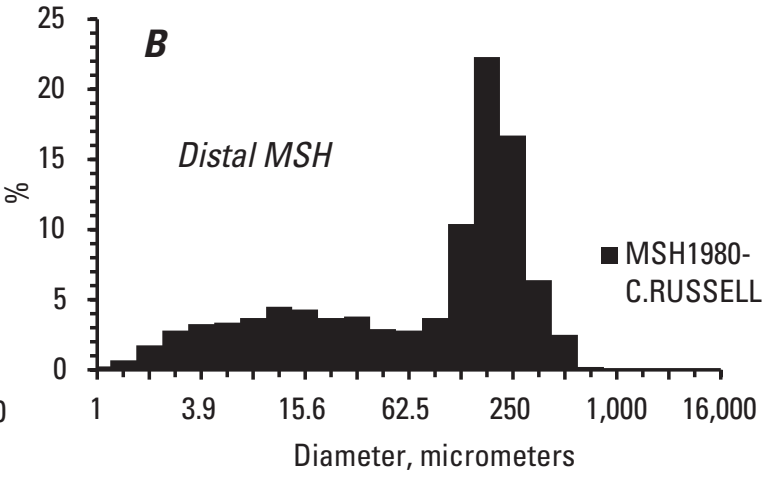

Valley of Ten Thousand Smokes, Alaska
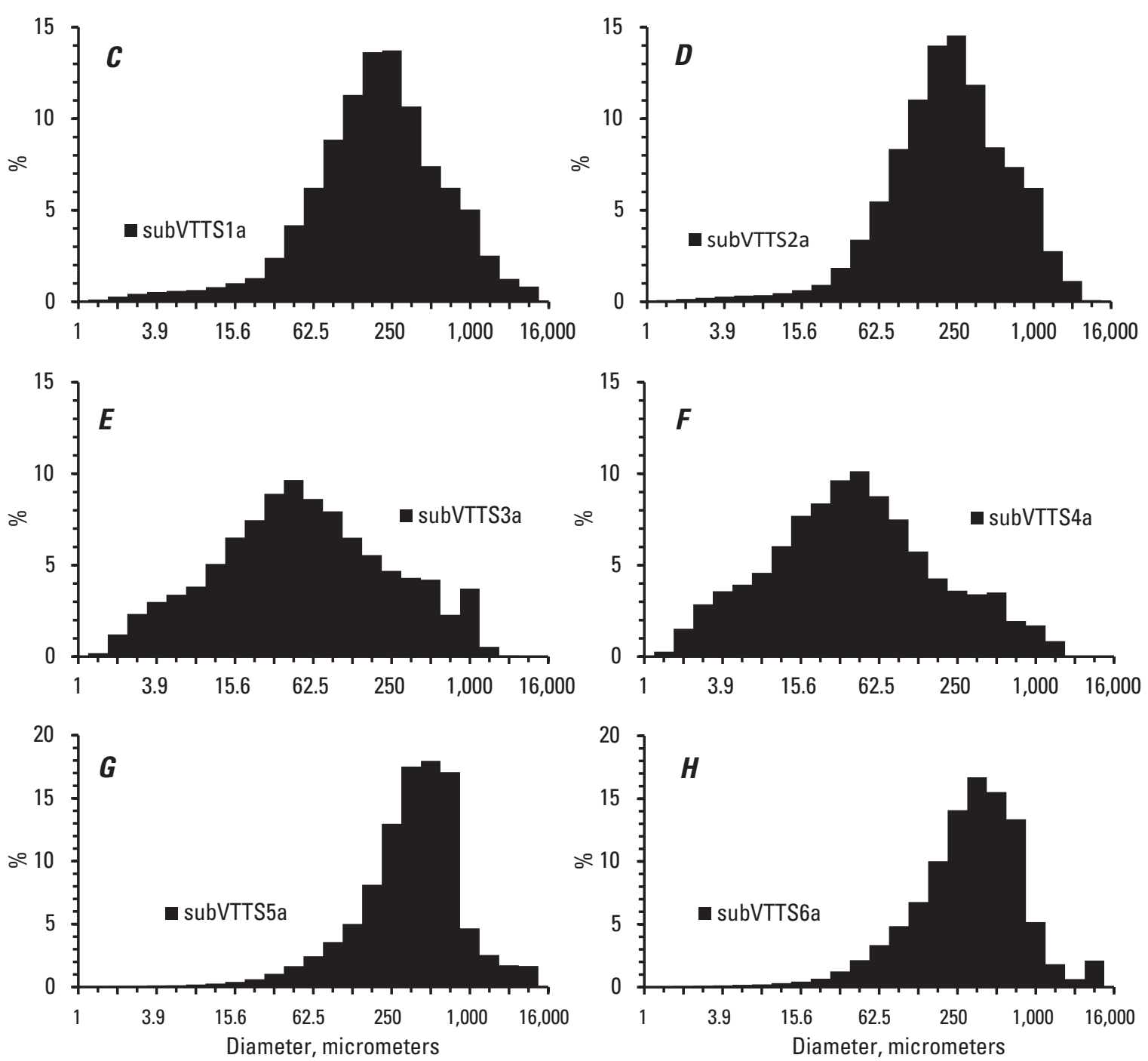

Figure 1.4. Histograms showing particle-size distributions from sieve-laser diffraction analysis of each volcanic ash sample collected in the field. Note values are reported as percent within each size class, rather than cumulative percent as shown in table 1.2. Size bins are in half-ø increments from 1 micrometer to 1 millimeter (mm), and whole-ø increments from 1-16 mm. \%, percent. 
experiments (fig. 1.5) is almost entirely less than $32 \mu \mathrm{m}$ and contains significantly more PM10 (75-83 percent) and PM2.5 (7-10 percent). These numbers vastly underestimate the PM2.5 fraction because particles smaller than $2.5 \mu \mathrm{m}$ were removed during the lab's collection process. The implication is that primary ashfall from an explosive eruption could transport significant quantities of extremely fine ash to Hanford, but resuspension by the wind would concentrate and re-entrain the sizes most relevant to air filtration systems.

Another observation is that the proximal sample of MSH 1980, collected $8 \mathrm{~km}$ from the volcano, contains substantially more fine ash than the distal fall deposit that landed in eastern Washington (fig. 1.4). Table 1.2 shows that the proximal sample is 71 percent finer than $63 \mu \mathrm{m}$ compared to 35 percent at Yakima. The difference in PM10 content is somewhat less marked ( 22 percent versus 15 percent). The finer-grained nature of the proximal ash is clearly seen in figure 1.6A, which includes two additional ashfall samples that landed within 80 $\mathrm{km}$ of Hanford (reported by Durant and others, 2009). The contrast between proximal and distal samples mainly reflects their transport histories during different phases of the eruption. In this case, the proximal sample was sourced from the outer edges of pyroclastic flows on the afternoon of May 18. These ground-hugging currents simply did not travel as far as the higher-altitude vertical plumes, so all their mass - even the finest particles - deposited closer to the volcano. The key message is that both samples are useful for evaluating the range of possible size distributions transported by a Mount St. Helens eruption. To demonstrate this, figure $1.6 B$ shows the proximal sample alongside the total grain-size distribution of the entire May 18, 1980, fall deposit from Durant and others (2009), which integrates several ashfall samples at different sites to reconstruct the original size population as it exited the volcano. The two plots show roughly comparable amounts of PM10, suggesting that the proximal sample is well within the expected range of size distributions produced by the May 18, 1980, eruption.

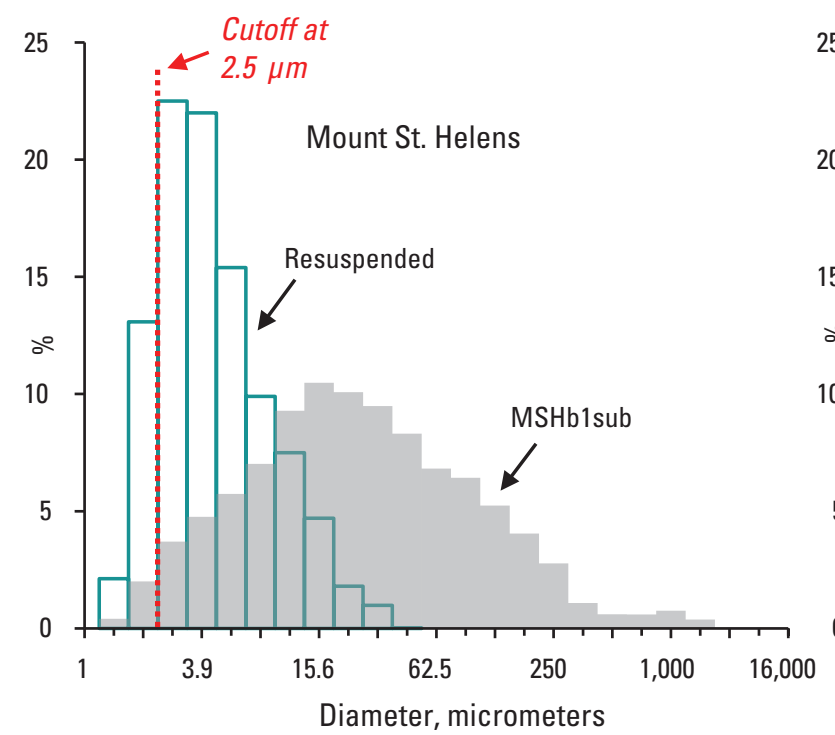

Diameter, micrometers

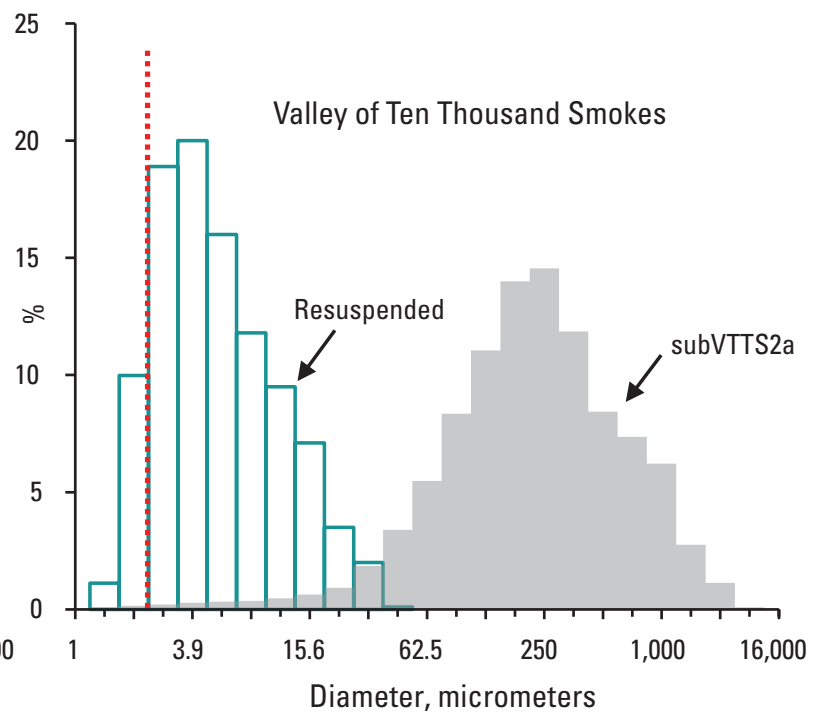

Diameter, micrometers

Figure 1.5. Comparison of parent versus resuspended ash from Portable In Situ Wind ERosion Lab (PI-SWERL) laboratory experiments, using material from Mount St. Helens, Washington, and the Valley of Ten Thousand Smokes, Alaska. Grain-size distributions are from sieve-laser diffraction data in table 1.2. The size distributions of resuspended ash from the two locations are nearly identical, despite very different parent material. The PI-SWERL laboratory instrument is designed to sample only the particles coarser than 2.5 micrometer $(\mu \mathrm{m})$ "aerodynamic" diameter from the resuspended ash (labeled cutoff in this plot), although laser diffraction does show a small amount of material less than $2.5 \mu \mathrm{m}$ "optical" diameter. \%, percent. 


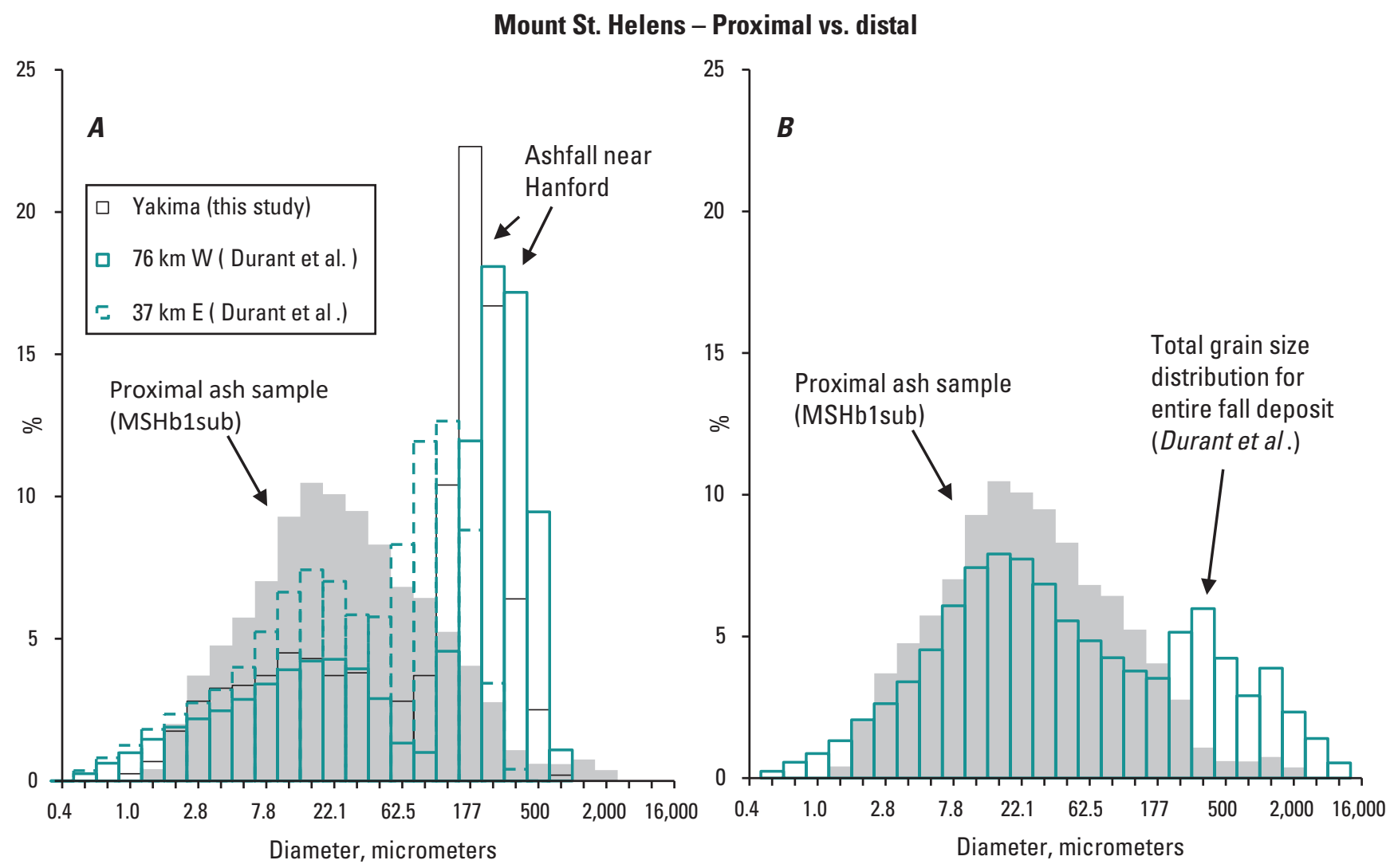

Figure 1.6. Histograms showing comparison of the particle-size distribution of the proximal May 18, 1980, ash sample from this study (gray bars) with other samples from the same eruption. A, Compares with three samples collected from the Hanford, Washington area, including the Yakima, Washington sample analyzed in this study (MSH1980-C.RUSSELL) and sites 37 kilometers $(\mathrm{km})$ east (DZ 21_12) and $76 \mathrm{~km}$ west of Hanford (DZ 20_6) reported by Durant and others (2009). B, Compares with the total grainsize distribution of the entire May 18, 1980, fall deposit reported by Durant and others (2009). \%, percent.

\section{Morphology of the Volcanic Ash Particles}

Results of shape analyses are tabulated in spreadsheet A2 of the data repository (Mastin and others, 2020). The aerodynamic properties of volcanic ash and entrapment by filters are both influenced by the shape of the particles (Wilson and Huang, 1979). Figure 1.7 shows distribution of long axes in each of the three samples, based on feret diameter. Although these particles were sieved between $32-63 \mu \mathrm{m}$, their long axes are generally much larger, in the range of $60-100 \mu \mathrm{m}$, owing to the presence of elongate particles, particularly in the sample from the Valley of Ten Thousand Smokes (subVTTS2a). Figure 1.8A illustrates this particle elongation with a plot of axial ratios, which is the ratio of intermediate to long axes. The VTTS sample contains higher proportions of elongate grains compared to the proximal and distal MSH ash, perhaps reflecting differences in the style of magma fragmentation. For example, magma breakage may have occurred along bubble walls that were more elongate than in the Mount St. Helens 1980 magma. Elongate bubbles are visibly more common in scanning electron microscope (SEM) images of the VTTS ash (fig. 1.1H).

Another important observation is particle roughness, which is strongly affected by the presence of vesicular glass. The distal MSH sample from Yakima is an outlier in this regard. Both in terms of solidity (fig. 1.8b) and form factor (fig. 1.8c), it contains significantly more particles with smooth outlines, indicating less vesicular glass. Lower vesicularity is linked to the magma ascent and fragmentation processes associated with the earliest phase of the May 18th eruption. The sample was collected during the first few hours of ashfall in Yakima, at a time when the eruption was expelling a less vesicular batch of magma known as the cryptodome. The cryptodome magma rose slowly in the volcanic edifice and had time to partially degas before generating the lateral blast and its associated far-traveled ash plume (Hoblitt and Harmon, 


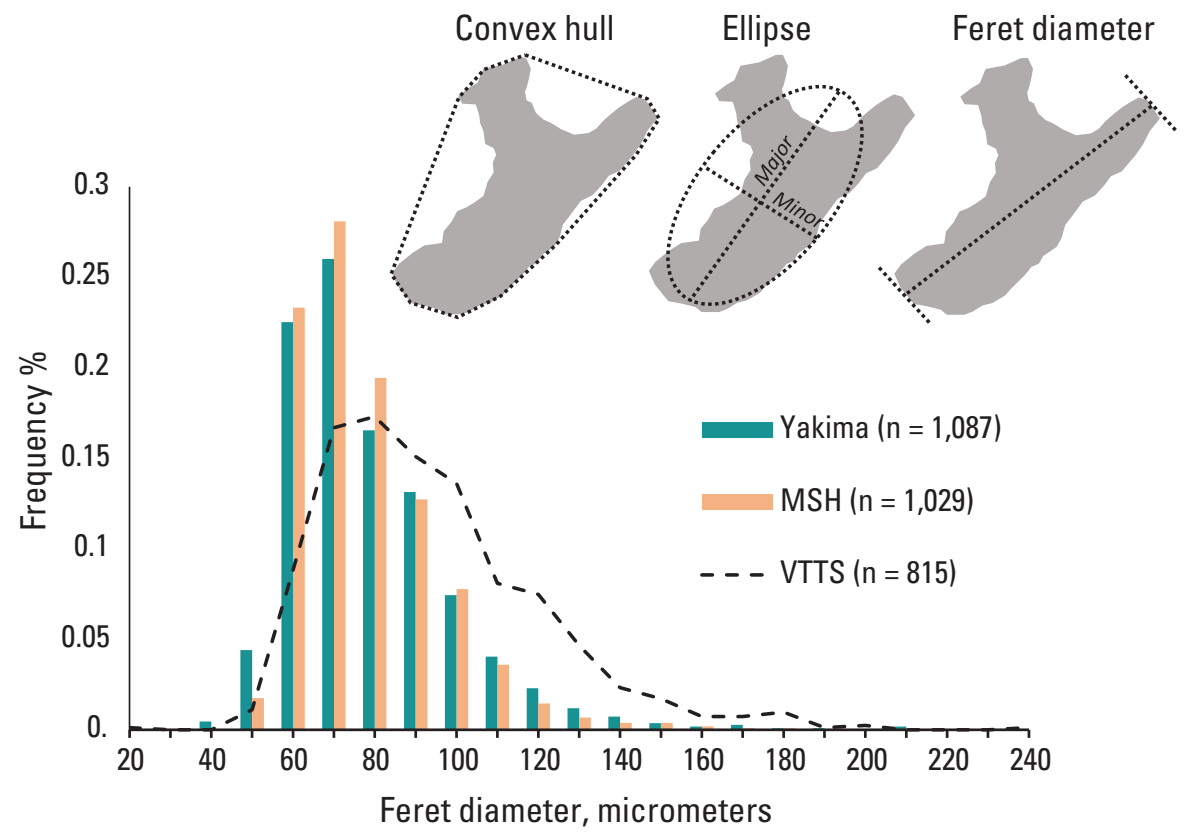

Figure 1.7. Histogram of feret diameters (in micrometers $[\mu \mathrm{m}]$ ) from each of the samples analyzed for shape, where $n$ gives the number of grains used for each sample (meeting or exceeding the threshold of 750 pixels per particle). The green bar is from Yakima, Washington, sample MSH1980-C.RUSSELL; the yellow bar is from Mount Saint Helens (MSH), sample MSHb1sub; and the dashed black line is from the Valley of Ten Thousand Smokes (VTTS), sample subVTTS2a. The particles were sieved between 32-63 micrometers for analysis, but their feret diameters (long axes) are mainly in the range of $60-90 \mu \mathrm{m}$ owing to the presence of elongate grains. Note that the Valley of Ten Thousand Smokes sample contains the longest feret diameters for the same sieve fraction, indicating a greater proportion of elongate grains. \%, percent.
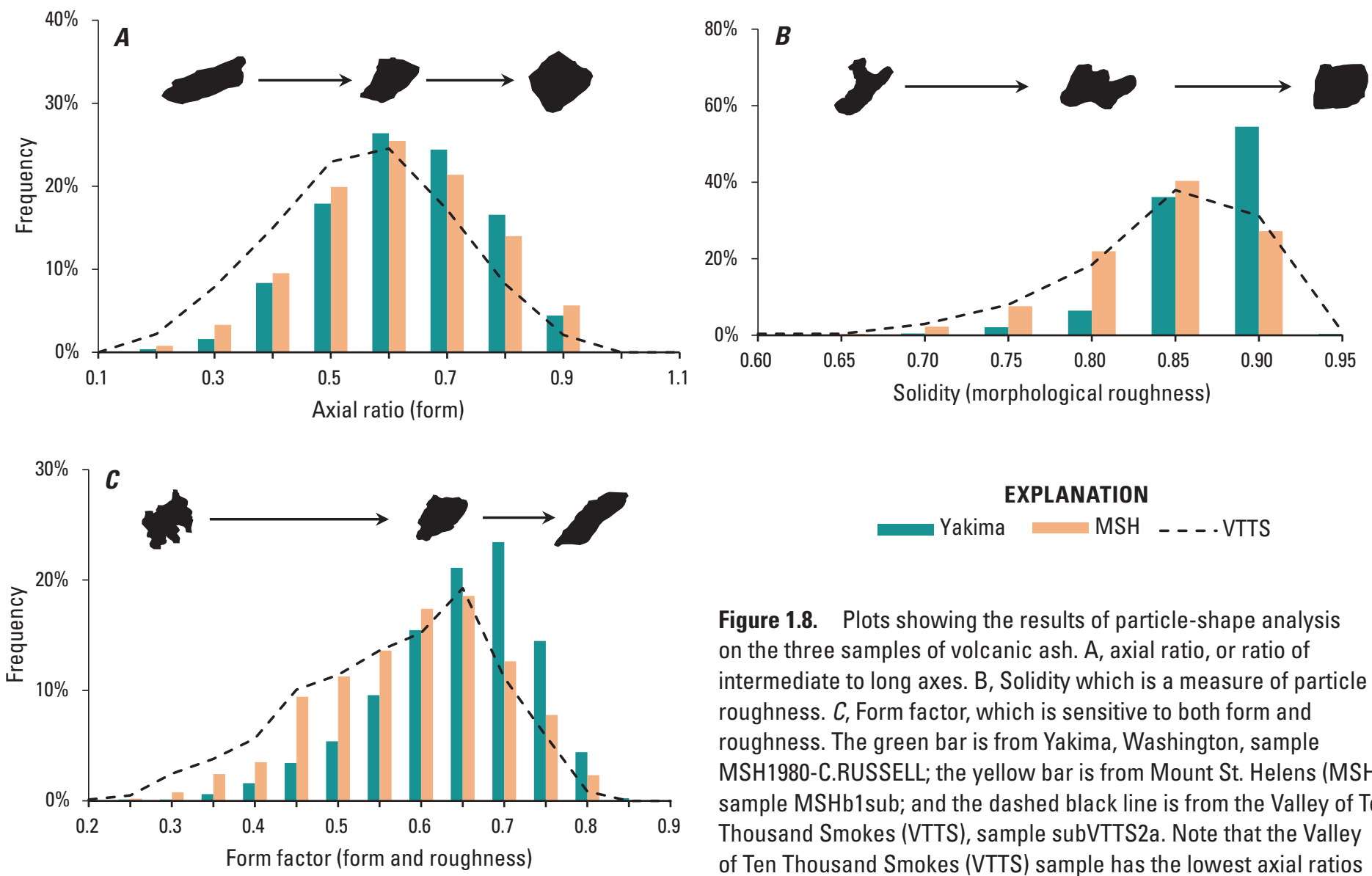

Figure 1.8. Plots showing the results of particle-shape analysis on the three samples of volcanic ash. A, axial ratio, or ratio of intermediate to long axes. B, Solidity which is a measure of particle roughness. $C$, Form factor, which is sensitive to both form and roughness. The green bar is from Yakima, Washington, sample MSH1980-C.RUSSELL; the yellow bar is from Mount St. Helens (MSH), sample MSHb1sub; and the dashed black line is from the Valley of Ten Thousand Smokes (VTTS), sample subVTTS2a. Note that the Valley of Ten Thousand Smokes (VTTS) sample has the lowest axial ratios because of elongate particles, and distal Mount St. Helens (MSH) (Yakima) has the highest values of solidity and form factor owing to poorly vesicular particles. 
1993). This is quite a different scenario from the later phases of the May 18th eruption (and the 1912 eruption Novarupta) which involved actively vesiculating magma that rose quickly to the surface and erupted as vertical Plinian columns (Gonnermann and Houghton, 2012). The key message here is that different magma fragmentation processes can produce fartraveled volcanic ash in the Cascades, leading to deposition of different particle shapes. And yet, despite the clear differences among samples in terms of eruption dynamics and particle morphologies, they do plot in a relatively consistent range, with most axial ratios in the range of $0.4-0.8$, solidity $0.85-$ 0.90 , and form factor $0.45-0.75$ (fig. 1.8).

\section{Conclusions}

An analysis of particle size and shape distributions of volcanic ash from the May 18, 1980, eruption of Mount St. Helens and 1912 eruption of Novarupta, Alaska (Valley of Ten Thousand Smokes), reveals several observations relevant to the hazards of ashfall impacting Hanford from a future eruption in the Cascades.
1. Particle-size distributions transported to the Hanford area by a Mount St. Helens eruption will vary greatly depending on the dynamics of eruption and transport, but a reasonable expectation is that the content of PM10 (particles smaller than $10 \mu \mathrm{m}$ ) could be less than 1 percent to greater than 20 percent, with PM2.5 comprising as much as 2 percent of the ashfall deposit by mass.

2. Resuspension of the ashfall deposit by wind will preferentially loft the material less than $32 \mu \mathrm{m}$, leading to a substantially greater proportion of PM10 in the airborne population (much greater than 70 percent by mass).

There are distinct differences in particle morphologies of the three ash samples analyzed in this study, related primarily to magma fragmentation processes. But overall, they show a relatively consistent range of shape parameters, with most axial ratios in the range of $0.4-0.8$, solidity $0.85-0.90$, and form factor $0.45-0.75$. 


\title{
Appendix 2: Effect of Extremely Large Eruptions of Mount St. Helens on Tephra- Fall Thickness and Airborne Ash Concentration at the Hanford Site, Washington
}

\author{
by Larry G. Mastin, Michael Clynne, Manuel Nathenson, John Pallister, and Alexa Van Eaton
}

\section{Introduction}

In December 2018, the U.S. Geological Survey's Cascades Volcano Observatory submitted the main body of this report to the U.S. Department of Energy's Office of River Protection (DOE-ORP), estimating the thickness and airborne ash concentration that could occur at the Hanford, Washington, facility with an annual probability of 1 in 10,000 during a future eruption of Mount St. Helens (MSH). To make this estimate, we ran approximately 10,000 model simulations of a hypothetical MSH eruption, randomly sampling erupted volumes within the range that are recorded in the Holocene stratigraphic record at MSH. The largest Holocene tephra deposit at MSH, the Yn, has a dense-rock-equivalent (DRE) volume between 0.8 and 2.3 cubic kilometers $\left(\mathrm{km}^{3}\right.$; Nathenson, 2017). The maximum volume we used for our modeling, $2.3 \mathrm{~km}^{3} \mathrm{DRE}$, was a key input.

In July 2019, DOE-ORP forwarded us the Staff Factual Accuracy Check and Staff Review of our analysis, written by the Defense Nuclear Facilities Safety Board (DNFSB) staff. The Accuracy Check noted some key concerns, specifically:

1. The maximum eruption volume used in our analysis was "non-conservative". The DNFSB staff cited an International Atomic Energy Agency document, IAEA-TEC-DOC-1795, Volcanic Hazards Assessments for Nuclear Installations, 2016 (International Atomic Energy Agency, 2016), which recommends that volcanic hazard assessments for nuclear facilities consider volcanic activity extending back 10 million years. "Including data from 10,000 years to 10 million years ago would have resulted in a larger estimated maximum erupted volume $\left(V_{\max }\right)$ and would therefore increase anticipated ashfall thickness and concentration values." The DNFSB staff was not persuaded by previous assessment and appraisal from the U.S. Geological Survey (USGS) that the magma system for Mount St. Helens was different during pre-Holocene time, and that larger pre-Holocene eruptions did not reflect the current composition and (or) size of the magma system.

2. The maximum estimated volume for the $\mathrm{Yn}$, $2.3 \mathrm{~km}^{3}$, was used as an absolute upper bound and we did not consider aleatoric variability and epistemic uncertainty.

The USGS provides this report to address those concerns. In our modeling, we chose the $\mathrm{Yn}$ as the upper endmember because it was the largest Holocene eruption, and because it occurred in a magma system that in some way resembles the current one. We did not examine older eruptions because the lack of adequate geological and physical evidence makes estimates of their size impractical; however, we should at least consider the probability of eruptions bigger than the Yn. In this report, we examine evidence of larger eruptions, run additional models, and reach three conclusions: (1) that the Yn eruption is likely the largest at Mount St. Helens over at least the past 50,000 years; (2) that the annual probability of larger eruptions is likely about $10^{-5}$ or less, and (3) that including eruptions larger than the $\mathrm{Yn}$ in our analysis, weighted by their probability, does not change our estimates of thickness or airborne concentration by more than a few tens of percent, for the 1-in-10,000 year event. These variations are within the range of other uncertainties in our analysis.

\section{Size of the Largest Eruptions at Mount St. Helens}

The oldest rocks that make up Mount St. Helens are a few hundred thousand years old (Clynne and others, 2008). The area around the volcano was glaciated several times before about 10 kilo-annum (ka) and older tephras were mostly removed; thus, older tephras are known primarily from distal locations. The biggest late-Pleistocene tephras known from MSH are the C-set tephras (Mullineaux, 1996), at least four of which are exposed in the eastern Washington Palouse (Busacca and others, 1992). The younger two correlate with $\mathrm{Cw}$ and $\mathrm{Cy}$ (Busacca and others, 1992), with ages in the 45-50,000-year range. One of the two older $\mathrm{C}$ tephras was dated at $83 \pm 8.3 \mathrm{ka}$ by thermoluminescence (Berger and Busacca, 1995), and it is not a $\mathrm{C}$ tephra recognized proximally. The age of the fourth Set $\mathrm{C}$ tephra was estimated by deposition rate to be as old as about $120 \mathrm{ka}$ and is also probably not preserved proximally.

We have no estimates of the volume of these older eruptions, but in the most comprehensive study of MSH tephras, Mullineaux (1996) implies that they were big. In his abstract, and his summary of Ape Canyon Stage volcanism, Mullineaux (1996) describes a late Set C tephra (probably Cy) as the largest known Mount St. Helens tephra of Pleistocene age. "One of them erupted near the end of Ape Canyon time, records one of the largest [italics ours] volume tephra eruptions known for MSH and has been recognized as far away as Nevada.". Also, in the abstract and discussion of Spirit Lake Stage volcanism (Mullineaux, 1996, abstract)) 
states: "One of the coarse layers, layer Yn, is the largest volume Holocene tephra known from Mount St. Helens." Carey and others (1995) echo that statement: "Layer Yn (3,510 years before present.) represents the highest intensity and largest magnitude eruption at Mount St. Helens in postglacial times."

The best available indicator of the size of late-Pleistocene tephras, relative to the $\mathrm{Yn}$, is their thickness at comparable distances along their dispersal axes (table 2.1). The $\mathrm{Cb}$ tephra is about 100 centimeters $(\mathrm{cm})$ thick at $8-11$ kilometers $(\mathrm{km})$ downwind (Mullineaux, 1996, Fig. 11). At the same distance downwind, $\mathrm{Cw}$ is $40 \mathrm{~cm}$ and $\mathrm{Cy}$ is $60 \mathrm{~cm}$, and the other Set $\mathrm{C}$ tephras are thinner. Yn is about $200 \mathrm{~cm}$ thick, and $120-180 \mathrm{~cm}$ at $18 \mathrm{~km}$ (Carey and others, 1995, Fig. 3c; Mullineaux, 1996, Fig. 40B). Also at $8-10 \mathrm{~km}$ distance, the $\mathrm{Wn}$, the second largest Holocene tephra, is $180 \mathrm{~cm}$ thick (Carey and others, 1995, Fig. 7a; Mullineaux, 1996, Fig. 61E). In these proximal locations, the $\mathrm{Yn}$ is the thickest known MSH tephra. Studies of distal Cascade tephras from the American West or Canada (Jensen and others, 2019) also recognize the Yn as being the most widespread Mount St. Helens tephra.

There are caveats with this conclusion of course. Exposures of the Pleistocene tephra set C-set are sparser than of Holocene tephras; and for this reason, we are less confident that the $\mathrm{C}$-set thicknesses observed at $8-11 \mathrm{~km}$ distance are along the dispersal axis. Moreover, because exposures degrade with time, the older tephras at distal sites will be less prominent. Despite those caveats, we have found no evidence of any MSH tephras thicker than the Yn.

Table 2.1. Thickness of the largest tephra layers at Mount St. Helens, at 8-11 kilometers from the vent.

[Data from Mullineaux (1996, Table 4). Abbreviations: cm, centimeter; $\mathrm{km}$, kilometer]

\begin{tabular}{lc}
\hline Unit & Thickness at 8-11 $\mathbf{~ m}$ distance (cm) \\
\hline $\mathrm{Wn}$ & 180 \\
$\mathrm{Yn}$ & 200 \\
$\mathrm{Cy}$ & 60 \\
$\mathrm{CW}$ & 40 \\
$\mathrm{Cb}$ & 100 \\
\hline
\end{tabular}

\section{Probability of an Eruption Larger than the Yn}

Even if the Yn were the biggest of the MSH tephra eruptions, the probability of a larger eruption must be greater than zero. In order to assign the size and probability of this larger eruption, we must consider a larger dataset.

The world's volcanic activity is chronicled by the Smithsonian Institution. Their Global Volcanism Program Volcanoes of the World (GVP) Database (https://volcano.si.edu/) lists all known historical eruptions worldwide, plus all older Holocene eruptions that are known from deposits rather than direct observations. Where possible, the size of each eruption is assigned using the Volcanic Explosivity Index (VEI); a complicated ranking that uses both plume height and tephra volume to derive a number from 0 to 8 . Considering only tephra volume, eruptions of VEI 3, 4, 5, 6, and 7 have bulk volumes exceeding $0.01,0.1,1,10$, and $100 \mathrm{~km}^{3}$ respectively. Nathenson (2017) estimates the bulk volumes of the 1980, the Wn, and the Yn tephra deposits as 1.1, 0.7-4, and 2-9 $\mathrm{km}^{3}$ respectively, ranking them all as VEI 5 on this scale. Nathenson's (2017) $9 \mathrm{~km}^{3}$ maximum tephra volume for the Yn converts to our modeled maximum dense-rock-equivalent (DRE) volume of $2.3 \mathrm{~km}^{3}$, using Nathenson's densities of 600 kilograms per cubic meter $\left(\mathrm{kg} / \mathrm{m}^{3}\right)$ and $2,300 \mathrm{~kg} / \mathrm{m}^{3}$ for the deposit and the magma, respectively.

Nathenson's (2017) volume estimate for the Yn ranks it as a large VEI 5 eruption. Among all eruptions in the GVP database, eruptions of size VEI 6 and larger (roughly, those bigger than the $Y n$ ) are about three times less common than VEI 5 (table 2.2, columns 2 and 3). However, some types of volcanoes are more capable of large eruptions than others. The GVP data indicate for example that of 6,049 eruptions from stratovolcanoes (of which MSH is one) 127 are VEI 5 (column 4), and 24 are VEI 6 or greater. Thus VEI 6 or greater eruptions compose less than 0.5 percent of all eruptions, and about 2 percent of VEI 3 or greater eruptions.

Within the Cascade Range, scattered layers record the infrequent occurrence of very large tephra eruptions. Nathenson (2012, Table 4) has tabulated about 20 Cascade tephras with deposit volumes $(V)$ greater than $5 \mathrm{~km}^{3}$, and 12 with (V) greater than $10 \mathrm{~km}^{3}$, since 1.2 Ma. The volumes that form

Table 2.2. Number of eruptions in the Smithsonian Institution's Global Volcanism Program (GVP) Volcanoes of the World Database, listed by size (VEI) (Global Volcanism Program, 2013). Eruptions with no size assignment are listed under "??".

[Abbreviations: $\mathrm{km}^{3}$, cubic kilometer; VEI, Volcanic Explosivity Index; $\%$, percent]

\begin{tabular}{llrrcc}
\hline & Volume $\left(\mathbf{k m}^{3}\right)$ & \multicolumn{2}{c}{ All GVP } & \multicolumn{2}{c}{ Stratovolcanoes } \\
\hline VEI & \multicolumn{1}{c}{ Bulk } & Count & Percent & Count & Percent \\
\hline$? ?$ & & 2,251 & 23 & 1,318 & 22 \\
0 & $1 \times 10^{-5}-1 \times 10^{-4}$ & 804 & 8 & 174 & 3 \\
1 & $0.0001-0.001$ & 1,208 & 12 & 772 & 13 \\
2 & $0.001-0.01$ & 3,741 & 38 & 2,481 & 41 \\
3 & $0.01-0.1$ & 1,127 & 11 & 808 & 13 \\
4 & $0.1-1$ & 504 & 5 & 342 & 6 \\
5 & $1-10$ & 177 & 2 & 127 & 2 \\
6 & $10-100$ & 52 & 0.5 & 24 & 0.4 \\
7 & $100-1,000$ & 8 & 0.1 & 3 & 0.0 \\
\hline
\end{tabular}


this tally are mostly educated guesses using thicknesses extrapolated from a few outcrops or inferred from the size of a caldera. Some volumes have since been revised downward (Nathenson, 2017). But if we take these numbers at face value and plot them as a function of age (fig. 2.1), we can assess the eruptive frequency from the steepness of the curves. The frequency of eruptions with bulk volumes greater than $5 \mathrm{~km}^{3}$ (the blue curve of fig.2.1) appears dramatically greater in the past few tens of thousands of years than at earlier times. We do not think that this indicates an increasing rate of activity; more likely, it is an artifact of preservation. Tephra deposits get buried or eroded with time, and the smaller deposits disappear. The magenta curve of figure 2.1 represents the larger eruptions and shows a more constant rate since about $600 \mathrm{ka}-\mathrm{a}$ trend that suggests the record may be more complete over this time. The last 300 ky shows a rate somewhat higher - perhaps twice as high as the overall average since $600 \mathrm{ka}$. Ten eruptions with $V>10 \mathrm{~km}^{3}$ since $600 \mathrm{ka}$ implies a Cascade-wide annual probability of $1.6 \times 10^{-5}$. The somewhat higher rate in the past 300 ky suggests an annual probability of about $3 \times 10^{-5}$. Whether this probability is evenly distributed among all 18 volcanoes of the Cascade Range is debatable. MSH is currently the most explosive volcano, but geodetic, seismic, and petrologic data make it uncertain whether its magma body is large enough to feed such an event. If evenly distributed so that the annual probability of a VEI 6 or greater eruption is the same at all volcanoes, the annual probability of a larger than $10 \mathrm{~km}^{3}$ (bulk) eruption at MSH would be roughly $3 \times 10^{-5} / 18 \cong 2 \times 10^{-6}$. If concentrated at $\mathrm{MSH}$, the annual probability of a VEI 6 or greater there could be an order of magnitude higher. Corresponding recurrence intervals $\left(R_{V E I \sigma^{+}}\right)$of a larger than $10 \mathrm{~km}^{3}$ (bulk) eruption at MSH would be about 50,000 to 500,000 years. At this rate, we would expect at least a few such eruptions in the more than 300,000-year history of MSH. In the geologic record, we see no evidence for any such eruptions.

\section{Effect of Large Eruptions on our Model Results}

Our analysis and that of Hoblitt and Scott (2011), noted that MSH produced 4 large explosive eruptions in roughly the last 500 years. Nathenson's (2017) volume estimates suggest that these were VEI 3 or larger. To first order, the recurrence interval $R$ of these events is about one per century. If the recurrence interval $\left(R_{V E I 6^{+}}\right)$for VEI 6 or greater eruptions is between 50,000 and 500,000 years, then the conditional probability of a VEI 6 or greater eruption, given the occurrence of an eruption, would be roughly $R / R_{V E I \sigma^{+}}=0.0002$ to 0.002 . That is, for every VEI 6 or greater eruption, we would expect between 500 and 5,000 smaller (VEI 4-5) eruptions.

Including these larger eruptions with their appropriate conditional probability would require that we add between 2 and 20 larger eruptions to the roughly 10,000 we have run already. We have actually run 1,000 additional simulations with volumes of $2.3-40 \mathrm{~km}^{3}$ DRE. In table 2.3, we examine the effect on the thickness $\left(T_{10 k}\right)$, maximum $\left(C_{\max , 10 k}\right)$, and average $\left(C_{\text {avg, } 10 k}\right)$ airborne ash concentrations of adding $1,10,100$,

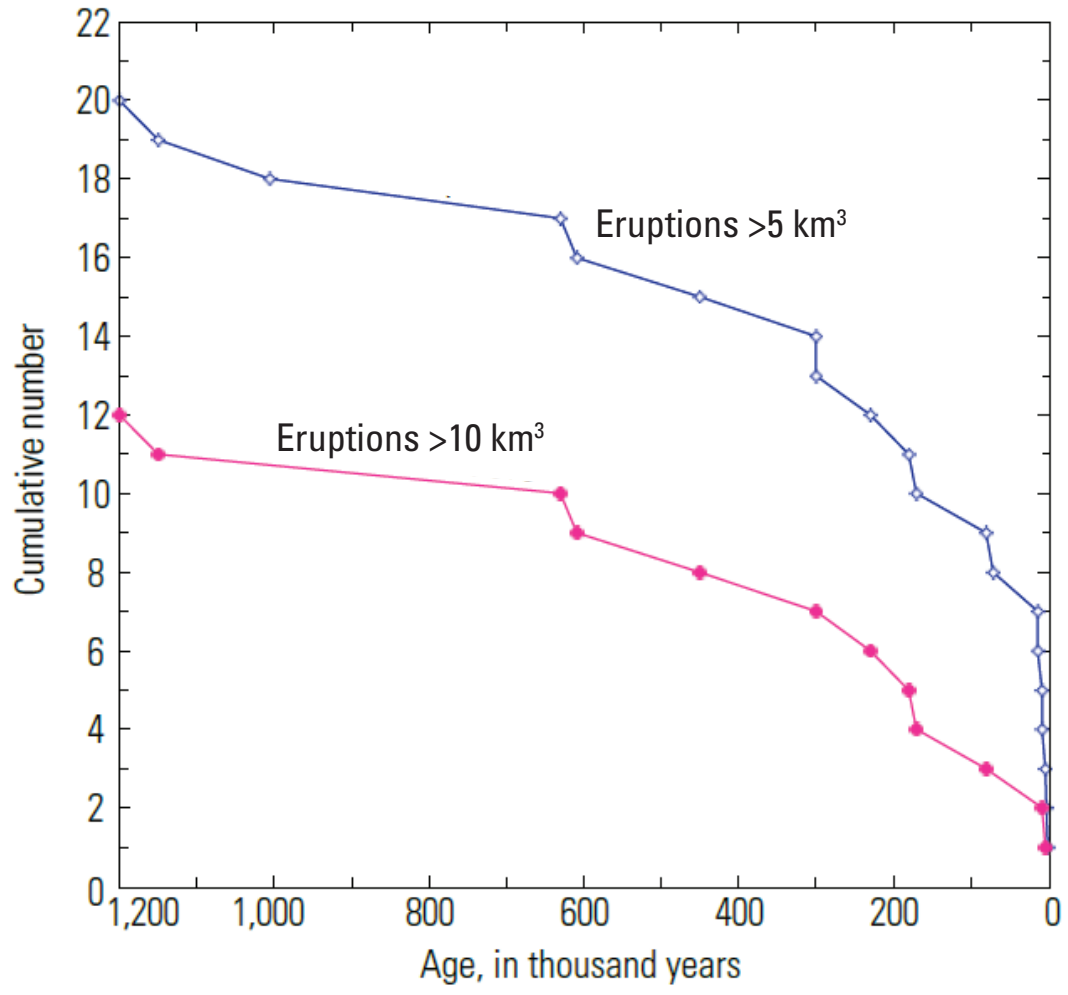

Figure 2.1. Graph showing the number of Cascade eruptions versus age, in thousands of years before present. Figure modified from Nathenson and others (2012, fig. 14). Blue line shows all eruptions with tephra volumes greater than about 5 cubic kilometers $\left(\mathrm{km}^{3}\right)$; magenta line shows all eruptions with tephra volumes exceeding about $10 \mathrm{~km}^{3}$. 
or all 1,000 to the simulations already run. Our objective is to examine the sensitivity of model results to different probabilities of high-volume eruptions. Volumes of these additional runs were assigned randomly using a uniform cumulative distribution on a log scale (fig. 2.2A). Model inputs and outputs from these runs is posted in tables BS1-BS3 of Mastin and others (2020). New values of the $T_{10 k}, C_{\max , 10 k}$, and $C_{a v g, 10 k}$ airborne ash concentrations at Hanford, having an annual probability of 1 in 10,000, were calculated using the same methodology as in our main report.

Table 2.3 shows that changes to $T_{10 k}, C_{\max , 10 \mathrm{k}}$, and $C_{\text {avg, }, 10 \mathrm{k}}$ from the addition of these runs are less than 40 percent, even when all 1,000 of the large-volume runs are added. The small effect is due in part to the fact that most simulations produced no deposit at Hanford (red dots, fig. 2.2b).

A second reason for the small effect is that we left most of the volume distribution intact, changing only the upper (high-volume) tail. Here, we also consider the effects of entirely different volume distributions. Figure $2.3 \mathrm{~A}$ shows the cumulative distribution function for our standard uniform distribution ( $\left.\mathrm{V}=0.008-2.3 \mathrm{~km}^{3} \mathrm{DRE}\right)$, compared with four others: our standard with 100 ("hi-V") high-volume runs added; our standard with 1,000 ('hi-V 10 percent") high-volume runs added; a uniform distribution from 0.1 $4 \mathrm{~km}^{3}$ based on MSH tephra volume estimates in Carey and others (1995) and used in an analysis reported to DOE in 2017 ("Carey"); and a new, hypothetical distribution ("Hypo"). The hypothetical distribution was constructed by starting with the

Table 2.3. Effect of the addition of a small number of highvolume simulations on the tephra-fall thickness $\left(T_{10 k}\right)$, maximum airborne ash concentration $\left(C_{\text {max.10k }}\right)$ and average airborne ash concentration $\left(C_{\text {avg, } 10 k}\right)$ at Hanford, Washington, having an annual probability of one in 10,000 .

[Abbreviations: $\mathrm{mg} / \mathrm{m}^{3}$, milligram per cubic meter; $\mathrm{mm}$, millimeter; yr, year; $\%$, percent; $\infty$,infinity]

\begin{tabular}{clccc}
\hline $\begin{array}{c}\text { Number (\%) } \\
\text { of runs added }\end{array}$ & $\begin{array}{c}\boldsymbol{R}_{\text {VEl6+ }} \\
\text { yrs }\end{array}$ & $\boldsymbol{T}_{10 k^{\prime}} \mathbf{m m}$ & $\begin{array}{c}\boldsymbol{C}_{\text {max, 10k }} \\
\mathbf{m g} / \mathbf{m}^{3}\end{array}$ & $\begin{array}{c}\boldsymbol{C}_{\text {avg, 10k }} \\
\mathbf{m g} / \mathbf{m}^{3}\end{array}$ \\
\hline $0(0 \%)$ & $\infty$ & 51.1 & 3819 & 1513 \\
$1(0.01 \%)$ & $1 \times 10^{6}$ & 51.1 & 3819 & 1513 \\
$10(0.1 \%)$ & $1 \times 10^{5}$ & 51.1 & 3856 & 1529 \\
$100(1 \%)$ & $1 \times 10^{4}$ & 51.8 & 3849 & 1568 \\
$1,000(9.3 \%)$ & $1 \times 10^{-3}$ & 62.6 & 4071 & 2083 \\
\hline
\end{tabular}
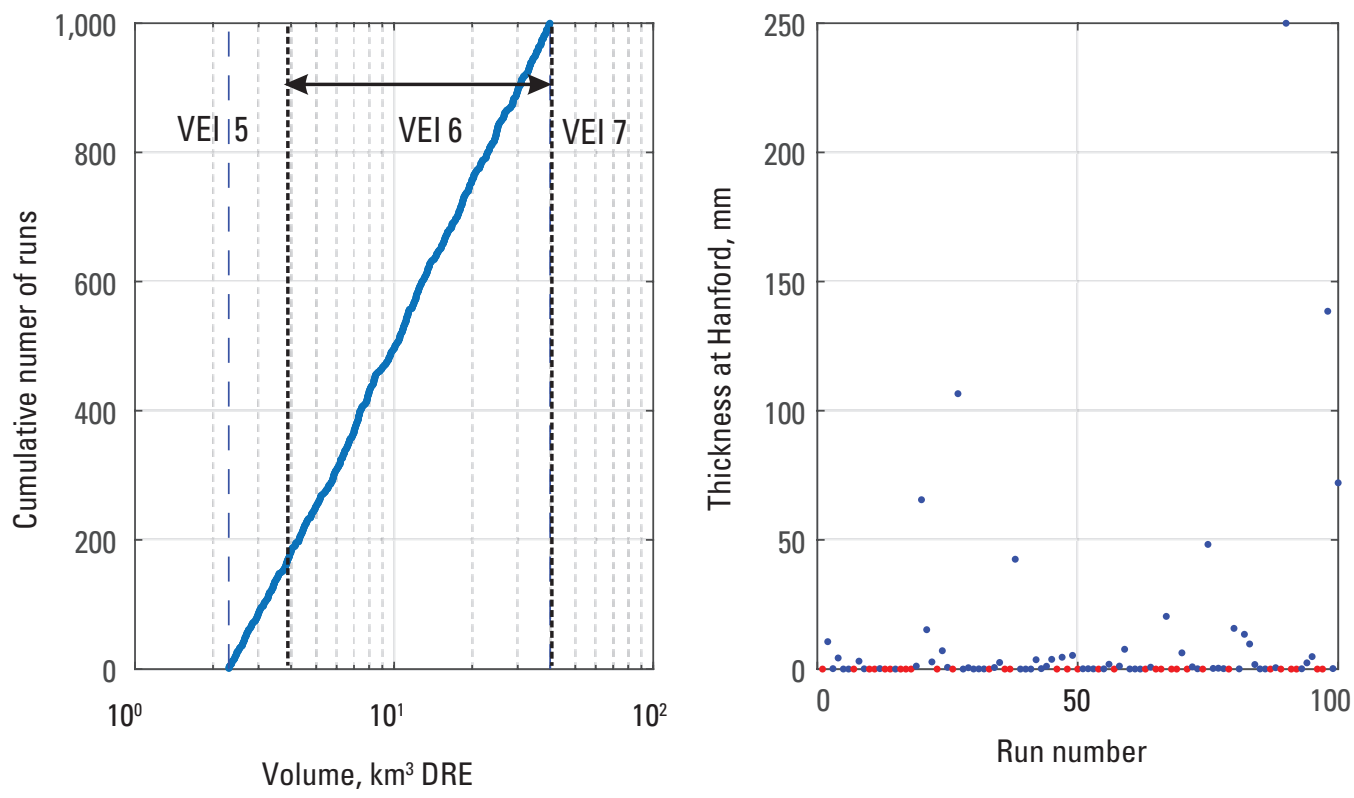

Figure 2.2. Graphs showing volume and thickness of tephra deposits indicated by model runs. $A$, Cumulative volume distribution of the 1,000 large-volume model simulations. Blue dashed line depicts a volume of 2.3 cubic kilometers $\left(\mathrm{km}^{3}\right)$ dense-rock equivalent (DRE). Black dashed lines separate Volcanic Explosivity Index (VEI) 5, 6, and 7 eruption sizes, using bulk tephra volume as the defining quantity for these VEI ranges and assuming tephra and DRE densities of 1,000 and 2,500 kilograms per cubic meter $\left(\mathrm{kg} / \mathrm{m}^{3}\right)$ respectively. The volumes are sampled from a distribution that is uniform on a log scale from 2.3 to $40 \mathrm{~km}^{3}$ DRE. $B$, Tephra deposit thickness at Hanford, Washington, as a function of the run number, for the first 100 model runs. Model runs with exactly zero thickness (T) at Hanford are represented by red dots, while those with $\mathrm{T}$ > 0.000 millimeters $(\mathrm{mm})$ are blue. 
standard distribution but increasing the frequency of larger eruptions under the assumption that the volumes of older deposits are toward the larger end of the uncertainty range. In particular, we assumed: (1) that most (about 95 percent) Holocene eruptions in the stratigraphy are at least VEI 4 in size; (2) that about 1 percent of eruptions in this record are VEI 6 or greater; and (3) that among eruptions in the VEI 4-5 range, about two thirds will be VEI 4, based on global trends (table 2.2). The percentage of VEI 6 or greater eruptions in this distribution ( 1 percent) is 5 to 50 times greater than the percentage we estimated earlier, based on Cascade Rangewide large eruption frequencies. The hypothetical distribution includes volumes extending to $40 \mathrm{~km}^{3}$ DRE. The probability density functions for these distributions are in figure $2.3 B-D$.

For each of these distributions, we calculated values of $T_{10 k}, C_{\text {max, } 10 k}$, and $C_{\text {avg, } 10 k}$ (table 2.4). Values based on the
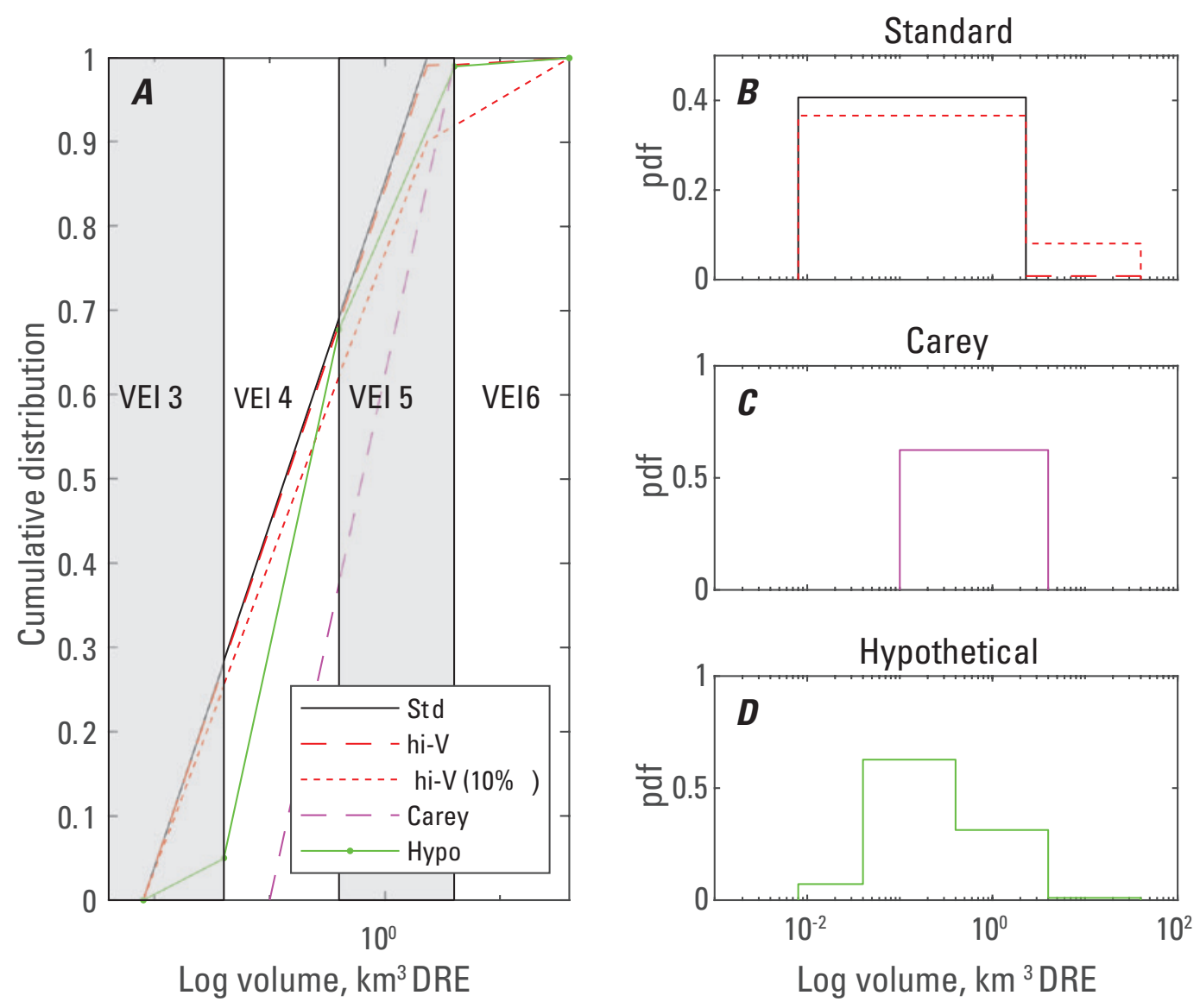

Figure 2.3. Graphs showing the cumulative distribution function and the probability distribution functions as a function of dense-rock equivalent (DRE) volume in cubic kilometers $\left(\mathrm{km}^{3}\right)$. $A$, Example cumulative distributions of DRE volume. Std (black line) is the the standard distribution used in our analysis; hi-V (high volume, dashed red line) is the modification to the standard distribution, with 100 (1 percent) high-DRE-volume eruptions added (barely distinguishable from the Std curve); hi-V (10 percent; dotted red line) is the modification to the standard distribution, with 1,000 (10 percent) high-volume eruptions added; Carey (dashed magenta line) is the volume range of Holocene eruptions used in an earlier version of our analysis, based on Mount St. Helens Holocene volume estimates of Carey and others (1995); and Hypo (solid green line) is a hypothetical distribution as explained in the text. Alternating gray and white zones show the regions where erupted volumes match the ranges for Volcanic Explosivity Index (VEI) 3, 4, 5, and 6, when calculated by converting dense-rock equivalent volume to bulk volume using assumed densities of 1,000 kilograms per cubic meter $\left(\mathrm{kg} / \mathrm{m}^{3}\right)$ for the deposit and $2,500 \mathrm{~kg} / \mathrm{m}^{3}$ for the magma. $B-D$ Probability density function (pdf) versus DRE volume showing: $B$, this study's standard distribution (with 1 percent and 10 percent hi-volume additions shown as a red dashed and red dotted lines, respectively); $C$, the volume distribution of Carey and others (1995); and $D$ the hypothetical distribution illustrated in $A$. 
Table 2.4. Values of tephra-fall thickness $\left(T_{10 k}\right)$, maximum airborne ash concentration $\left(\mathcal{C}_{\text {max }, 10 k}\right)$ and average airborne ash concentration $\left(C_{a v g, 10 k}\right)$ at Hanford, Washington, based on the distributions of eruptive volume given in figure 2.3.

[Abbreviations: $\mathrm{mg} / \mathrm{m}^{3}$, milligram per cubic meter; $\mathrm{mm}$, millimeter]

\begin{tabular}{lccc}
\hline \multicolumn{1}{c}{ Distribution } & $\begin{array}{c}\boldsymbol{T}_{\text {10k }} \\
\mathbf{m m}\end{array}$ & $\begin{array}{c}\boldsymbol{C}_{\mathbf{m a x}, \mathbf{1 0 k}} \\
\mathbf{m g} / \mathbf{m}^{3}\end{array}$ & $\begin{array}{c}\boldsymbol{C}_{\text {avg, 10k }} \\
\mathbf{m g} / \mathbf{m}^{3}\end{array}$ \\
\hline Standard & 51.1 & 3,819 & 1,513 \\
Standard+100 large runs & 51.8 & 3,849 & 1,568 \\
Carey & 105 & 7,387 & 3,018 \\
hypothetical & 55.1 & 4,410 & 2,148 \\
\hline
\end{tabular}

Carey and others (1995) DRE volume distributions were presented in a DOE meeting on October 2, 2017, and were based on about 10,000 additional simulations. Those for the hypothetical distribution were calculated by taking 3,000 of the about 11,000 runs (the original about 10,000 plus the 1,000 high-volume runs), to produce a population with the volume distribution shown.

The hypothetical distribution increases $T_{10 k}$ about 8 percent relative to the standard distribution. $C_{\max , 10 k}$ and $C_{a v g, 10 k}$ are 15 percent and 42 percent higher, respectively, than the standard distribution. In summary, these new values are within a few tens of percent of the ones we reported. The Carey and others (1995) DRE volume distributions, which we think overestimates volumes, gives $T_{10 k}$ roughly equal to the 100 mm value estimated by Hoblitt and Scott (2011), and concentration values about two times greater than our results using the standard distribution.

\section{Conclusions}

In the conclusions section of our original report, we characterized our results as order-of-magnitude estimates with large uncertainties. We also noted in the discussion section that these were "best estimates", made with no intent to add conservatism. We have taken seriously the concern that our modeling did not consider a finite probability of an eruption larger than $2.3 \mathrm{~km}^{3}$ DRE. In addressing this issue, we have shown (1) that there are no known eruptions from Mount St. Helens that are larger than $2.3 \mathrm{~km}^{3}$ DRE; (2) that Cascades eruptive history suggests an annual probability of a larger eruption to be on the order of $10^{-5}$ or less; and (3) that when one adds larger eruptions to our dataset, using appropriate conditional probabilities, the calculated thickness and concentration at Hanford are still within a few tens of percent of our original calculations.
Menlo Park Publishing Service Center, California Manuscript approved for publication November 9th, 2020 Edited by John Mark Brigham Layout by Kimber Petersen Illustration support by JoJo Mangano 


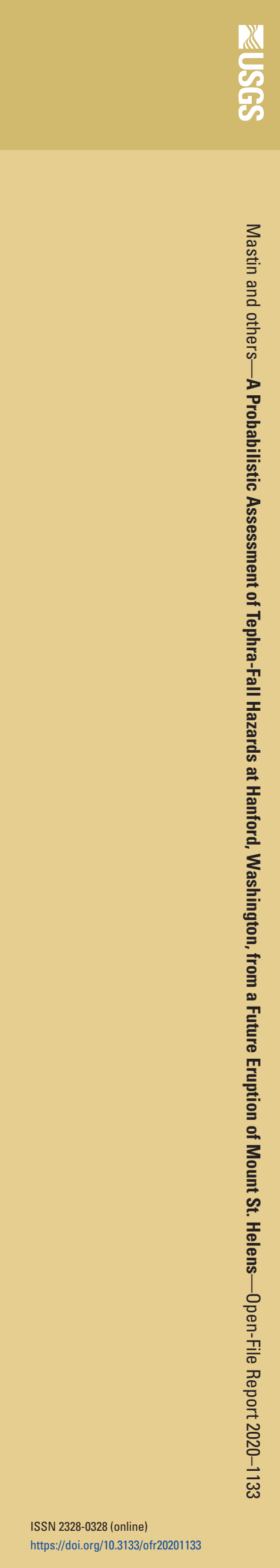

